INSTITUTO DE PESQUISAS ENERGÉTICAS E NUCLEARES

AUTARQUIA ASSOCIADA À UNIVERSIDADE DE SÃO PAULO

\title{
AVALIAÇÃO DO RISCO AMBIENTAL DE SEDIMENTOS CONTAMINADOS COM TRICLOSAN, IBUPROFENO E 17 $\alpha$-ETINILESTRADIOL EMPREGANDO INVERTEBRADOS MARINHOS BENTÔNICOS
}

FABIO HERMES PUSCEDDU

\author{
Tese apresentada ao Instituto de \\ Pesquisas Energéticas e Nucleares \\ como parte dos requisitos para \\ obtenção do título de Doutor em \\ Ciências, área de Tecnologia Nuclear - \\ Aplicações. \\ Orientador: \\ Prof. Dr. Jose Roberto Rogero \\ Co-orientador: \\ Prof. Dr. Augusto Cesar
}

São Paulo 
"Seja você quem for, seja qual for a posição social que você tenha na vida, tenha sempre como meta muita força, muita determinação e sempre faça tudo com muito amor e com muita fé em Deus, que um dia você chega lá. De alguma maneira você chega lá".

\section{Ayrton Senna}




\section{AGRADECIMENTOS}

Agradeço a Deus pelas oportunidades, desafios, força e presença constante em minha vida.

À minha família, por todo apoio, ajuda, compreensão e incentivo que foram fundamentais para o desenvolvimento deste trabalho.

Ao meu orientador Dr. Jose Roberto Rogero e a MSc. Sizue Ota Rogero, por todo apoio, ajuda, compreensão, aprendizado, incentivo e amizade. A confiança depositada por vocês desde o início foi fundamental para o desenvolvimento deste trabalho. Muito obrigado pela oportunidade!

Ao meu co-orientador Dr. Augusto Cesar pela paciência, o convívio, conselhos, amizade, incentivo, parceria e oportunidades desde o início da minha carreira. Você é fera!

Ao programa de Pós-Graduação em Tecnologia Nuclear do Instituto de Pesquisas Energéticas e Nucleares (IPEN-CNEN/SP), e ao Centro de Química e Meio Ambiente (CQMA) pela oportunidade e disponibilização da infraestrutura para a realização deste trabalho.

Ao grupo de Ecotoxicologia da Baixada Santista (UNISANTA, UNESP e UNIFESP):

Aos amigos do Laboratório de Ecotoxicologia da Universidade Santa Cecília, Tio Aldo, Fernando, Camilo e Augusto por todos os ensinamentos, pela paciência, o convívio, conselhos, amizade, incentivo e oportunidades desde o início. Trabalhar com vocês é uma honra e faz tudo ficar mais fácil! À Beatriz Barbosa Moreno e Caio Rodrigues Nobre pela participação direta nos "neutral reds" e separação de tecidos! À Mariana Aliceda e Aline Vecchio, por todo apoio, ajuda e momentos de descontração (\#Nitokra). Aos Profs. Walber Toma e Luciana Guimarães pelo apoio, dicas e oportunidades. À todos os estagiários do laboratório que contribuíram de uma forma ou de outra com a execução deste trabalho e partilharam de momentos desta etapa ao longo dos últimos anos. À toda direção da UNISANTA, especialmente ao Dr. Antônio de Salles Penteado, por todo apoio para execução deste trabalho.

Ao Dr. Denis Moledo de Souza Abessa pelo apoio, dicas no início deste estudo e disponibilização do seu laboratório para realização dos biomarcadores, e à toda sua equipe do Núcleo de Estudos em Poluição e Ecotoxicologia Aquática (NEPEA) da UNESP - Campus Litoral Paulista. Ao Lucas (Balu), Lucas (Geleia), Carol, Sinhá (Bruno), Mayana, Paloma (Diogo), Ney, Guacira, Giuliana (Malária), Mayra (Breja), Júlia, Heitor, Giam, Gabriel (Bodeia), Andrey (Buzina) e especialmente a Dra. Luciane Alves Maranho (Maranhola) por toda ajuda e apoio com os biomarcadores.

Ao Dr. Rodrigo Brasil Choueri da UNIFESP - Campus Baixada Santista por toda ajuda, amizade, discussões e aprendizado que foram fundamentais para o desenvolvimento deste trabalho, e a toda equipe de Ecotoxicologia da UNIFESP, especialmente a Manoela, Bruna, Renata, Vagner, Tierry e Joãozinho. 
Aos colegas e amigos do Centro de Química e Meio Ambiente do IPEN: Marycel, Denise, Elias, Cris, Nilce, Hélio, Davi, Carina, Ju Izidoro, Gisela e especialmente às Dras. Maria Aparecida Faustino Pires e Elaine Arantes Jardim Martins, por todo apoio, dicas e contribuições ao trabalho. Aos amigos e parceiros de projeto Dymes Rafael dos Santos pelo apoio e bons momentos dentro e fora do trabalho - e a Flávia Junqueira (in memorian), por toda ajuda e legado que marcaram para vida toda.

Ao MSc. Fernando Cesar Perina pela ajuda na identificação da espécie de Mytella utilizada neste estudo.

À equipe do Centro de Espectrometria de Massas Aplicadas (CEMSA) pela parceria na realização das análises químicas, especialmente aos amigos Mestres Daniel Temponi Lebre, Caroline Lima de Oliveira e Renan de Azevedo Silva.

Ao Dr. Marcos Leoni Gazarini Dutra do departamento de Biociências da UNIFESP (Campus Baixada Santista), pela disponibilização do laboratório para realização de alguns biomarcadores.

Ao Dr. Carlos Alberto Amaral Moino e equipe de engenharia mecânica da UNISANTA pela ajuda no desenvolvimento do Jar/Rolling, que está em vias de se transformar em uma patente.

Ao MSc. Renan Braga Ribeiro do Núcleo de Pesquisas Hidrodinâmicas da UNISANTA pelo apoio no desenvolvimento dos mapas.

À Gabriela Muchon Simões por todo apoio, amizade, paciência, parceria e força que foram fundamentais para realização desse trabalho.

Ao CNPq - Conselho Nacional de Desenvolvimento Científico e Tecnológico (Processos № 481553/2012-6; ㄲo 481358/2012-9) pelo apoio financeiro.

A todos que não foram citados aqui, mas que de uma forma ou de outra foram importantes durante a realização deste trabalho. 


\section{Avaliação do risco ambiental de sedimentos contaminados com triclosan, ibuprofeno e 17a-etinilestradiol empregando invertebrados marinhos bentônicos}

\section{Fabio Hermes Pusceddu}

\section{RESUMO}

Os protocolos de Avaliação de Risco Ambiental (ERA) de Fármacos e Produtos de Cuidados Pessoais (FPCP) recomendam o uso de ensaios ecotoxicológicos tradicionais (por exemplo algas, bactérias, invertebrados, peixes) e a avaliação de efeitos em um único nível de organização biológica para a determinação dos efeitos potenciais dos FPCP à biota. Considerando que efeitos em nível de sub-indivíduo pode afetar igualmente a aptidão ecológica de organismos marinhos, e que os mesmos estão cronicamente expostos aos FPCP, o objetivo do presente estudo foi avaliar o risco ambiental de triclosan (TCS), ibuprofeno (IBU) e 17a-etinilestradiol (EE2) em sedimentos marinhos utilizando respostas de efeitos sub-individuais e populacionais. Por meio do HPLC-ESI-MS/MS, as concentrações ambientais de TCS e IBU foram quantificadas em sedimentos marinhos coletados no entorno do emissário submarino de esgoto de Santos (Baía de Santos, São Paulo - Brasil) com 15,14 e 49,0 ng.g ${ }^{-1}$, respectivamente, enquanto o EE2 não foi detectado (<33 $\left.\mathrm{ng} \cdot \mathrm{g}^{-1}\right)$. Uma bateria de ensaios de toxicidade crônica (desenvolvimento embriolarval) com ouriços-do-mar (Lytechinus variegatus) e bivalves (Perna perna) foi realizada (efeito a nível de indivíduo) após exposição a sedimentos contaminados com os FPCP. Além disso, foram analisados alguns biomarcadores de Fase I (etoxiresorufina O-deetilase - EROD e dibenzilfluoresceína - DBF), de Fase II (glutationa S-transferase - GST) do metabolismo, do sistema antioxidante (glutationa peroxidase - GPx), de neurotoxicidade (colinesterase - ChE), de estresse oxidativo (peroxidação lipídica - LPO e danos em DNA) e de citotoxicidade que foram selecionados para avaliação das respostas a nível de sub-indivíduo em mexilhões Mytella charruana. Todos os compostos analisados apresentaram efeitos sobre o desenvolvimento embriolarval de $L$. variegatus e $P$. perna em concentrações ambientalmente relevantes. Em nível de sub-indivíuo foi possível observar que o TCS causou efeitos cito-genotóxicos 
(diminuição da estabilidade da membrana lisossomal, peroxidação lipídica e danos em DNA) e neurotóxicos. O IBU causou efeitos citotóxicos e neurotóxicos, enquanto o EE2 apresentou efeitos citotóxicos e danos em DNA. Nesse sentido, mesmo em baixas concentrações os FPCP são potencialmente capazes de alterar os mecanismos de manutenção da homeostase. Os dados químicos e ecotoxicológicos foram integrados e os quocientes de risco estimados para TCS, IBU e EE2 apresentaram valores superiores a 1,0, indicando alto risco ambiental destes compostos em sedimentos marinhos. Estes são os primeiros dados de avaliação de risco ambiental de FPCP em sedimentos de uma zona costeira brasileira. Os resultados sugerem que a ERA de fármacos e produtos de cuidados pessoais deve contemplar, além dos ensaios de toxicidade tradicionais o uso de biomarcadores como indicadores dos primeiros sinais de efeitos e, assim, estabelecer uma avaliação de risco mais efetiva que assegure a proteção e funcionamento dos ecossistemas aquáticos.

Palavras-chave: Avaliação de risco ambiental, triclosan, ibuprofen, 17a-etinilestradiol, poluentes emergentes, efeitos sub-letais, Lytechinus variegatus, Perna perna, Mytella charruana, esgoto doméstico. 


\title{
Environmental risk assessment of sediments contaminated with triclosan, ibuprofeno and 17a-ethynylestradiol employing benthic marine invertebrates
}

\section{Fabio Hermes Pusceddu}

\begin{abstract}
The guidelines for the Environmental Risk Assessment (ERA) of pharmaceuticals and personal care products (PPCPs) usually recommend the use of standard ecotoxicity assays (e.g. algae, bacteria, invertebrate, fish) and the assessment of endpoints at individual level for the evaluation of potential effects of PPCPs on biota. Considering that effects at sub-individual level can also affect the ecological fitness of marine organisms, and that marine organisms are chronically exposed to PPCPs, the aim of the current study was to evaluate the environmental risk of triclosan (TCS), ibuprofen (IBU) and 17aethynylestradiol (EE2) in marine sediments using sub-individual and population endpoints. Using LC-ESI-MS/MS, the environmental levels of TCS and IBU were quantified in marine sediments from the vicinities of the Santos submarine sewage outfall (Bay of Santos, São Paulo, Brazil) at 15.14 and $49.0 \mathrm{ng} \mathrm{g}^{-1}$, respectively, while EE2 was not detected (<33ng $\left.\mathrm{g}^{-1}\right)$. A battery $(\mathrm{n}=3$ ) of chronic bioassays (embryo-larval development) with a sea urchin (Lytechinus variegatus) and a bivalve (Perna perna) were performed at populational level after exposure to spiked sediment. Phases I (ethoxyresorufin O-deethylase - EROD and dibenzylfluorescein dealkylase - DBF) and II (glutathione S-transferase - GST) of the metabolism, antioxidant system (glutathione peroxidase - GPX), neurotoxicity (cholinesterase - ChE), oxidative effects (lipid peroxidation - LPO and DNA damage strand breaks) and cytotoxicity were selected to evaluate the sublethal responses in the bivalve Mytella charruana. These compounds showed developmental effects on $L$. variegatus and $P$. perna at environmentally relevant concentrations. At sub-individual level TCS induced cyto-genotoxic (reduction on stability of lysosome membrane, lipid peroxidation and DNA damage) and neurotoxic effects. IBU caused cyto and neurotoxic effect, while EE2 caused cytotoxic and DNA damage. Chemical and ecotoxicological data were integrated and the quotient risk estimated for TCS, IBU and EE2 showed values
\end{abstract}


higher than 1.0, indicating high environmental risks of these compounds in sediments. These are the first data of risk assessment of pharmaceuticals and personal care products in sediments of a Brazilian coastal zone. The results suggests that the ERA of pharmaceuticals and personal care products must include, in addition to the standard toxicity tests, the use of biomarkers as indicators of the early warning signs and thus provide a more effective risk assessment to security the protection and functioning of aquatic ecosystems.

Key words: Environmental risk assessment, triclosan, ibuprofen, 17a-ethynylestradiol, emerging pollutants, sublethal effects, Lytechinus variegatus, Perna perna, Mytella charruana, domestic sewage. 


\section{SUMÁRIO}

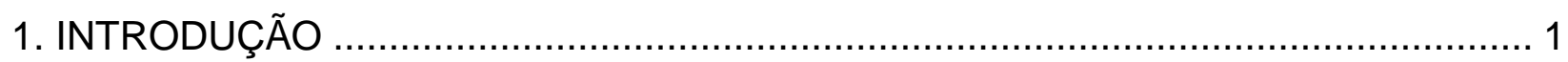

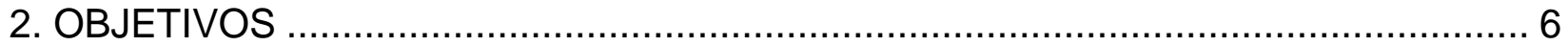

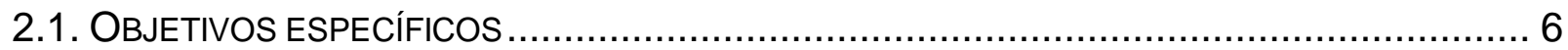

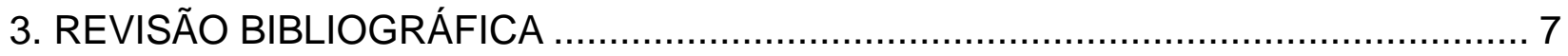

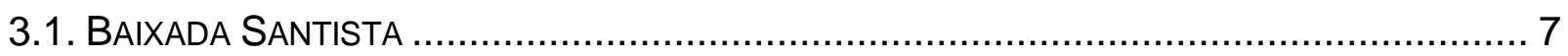

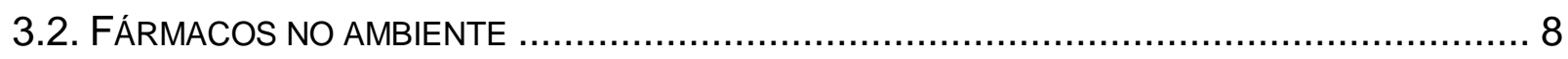

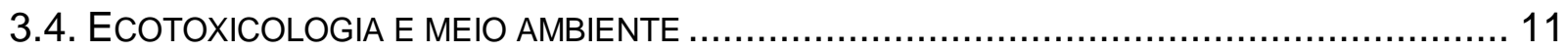

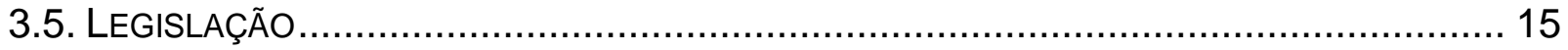

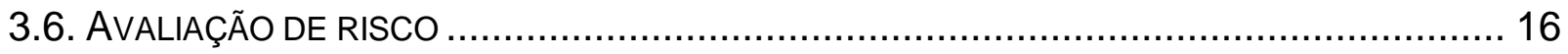

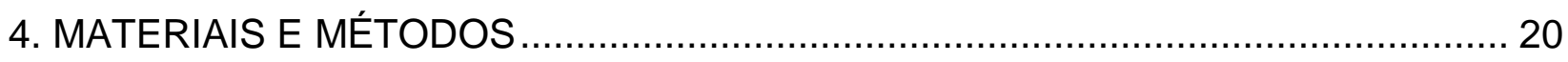

4.1. ColetA, MANUTENÇÃO E CULTIVO DE ORGANISMOS-TESTE …............................... 20

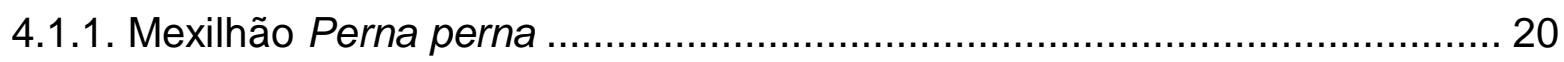

4.1.2. Ouriço-do-mar Lytechinus variegatus................................................... 20

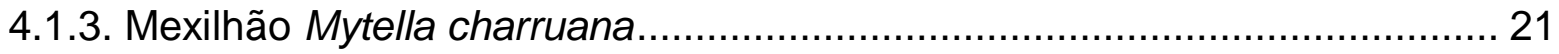

4.2. CARACTERIZAÇÃO DOS FPCP EMPREGADOS NO ESTUDO..................................... 22

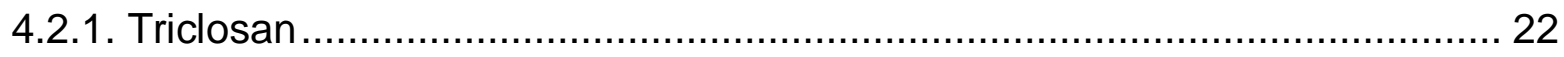

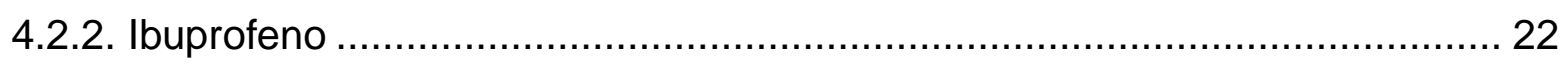

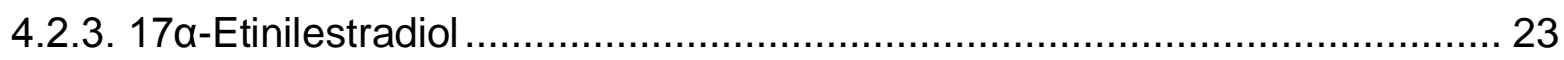

4.3. AVALIAÇÃO ECOTOXICOLÓGICA DOS SEDIMENTOS ................................................ 24

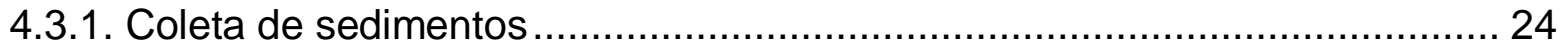

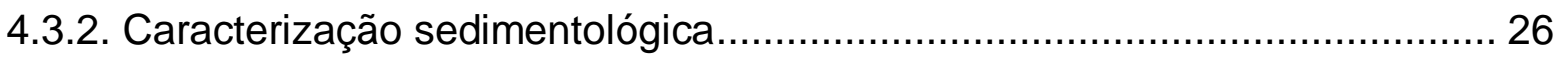

4.3.3. Marcação do sedimento (Spiked-sediment) ........................................... 26

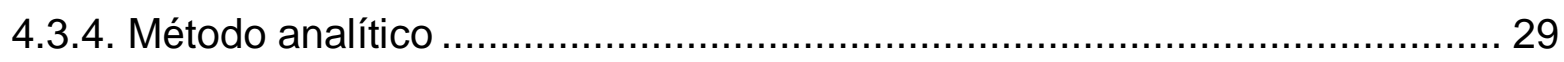

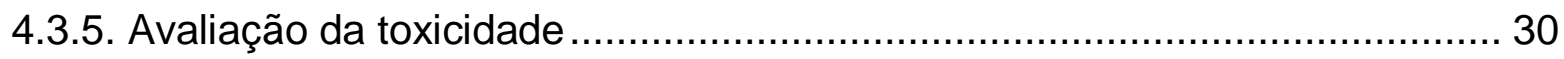

4.3.5.1. Ensaios de toxicidade com mexilhão Perna perna ................................. 31

4.3.5.2. Ensaios de toxicidade com ouriço-do-mar Lytechinus variegatus .............. 33

4.3.5.3. Ensaio de citotoxicidade com mexilhão Mytella charruana........................ 36

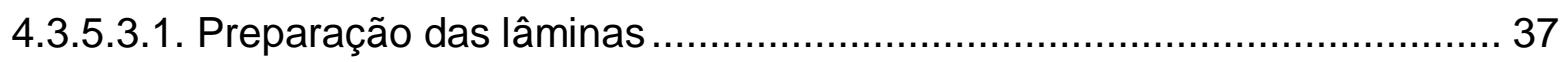

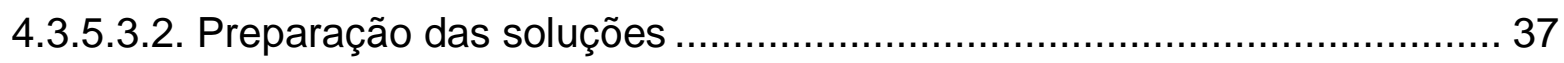

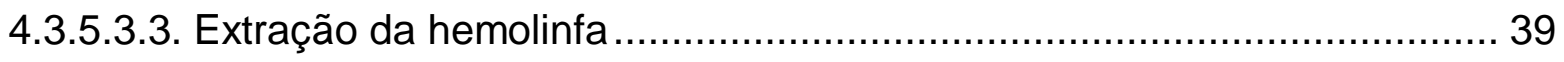

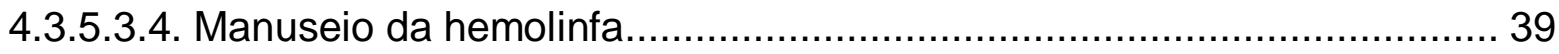




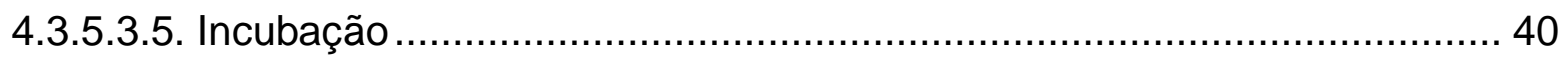

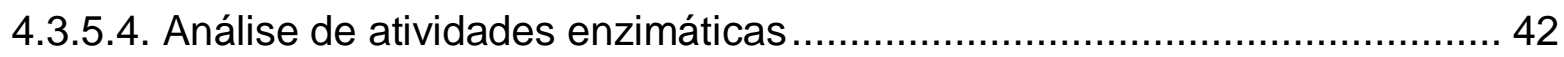

4.3.5.4.1. Etoxiresorufina-O-deetilase (EROD) ….......................................... 43

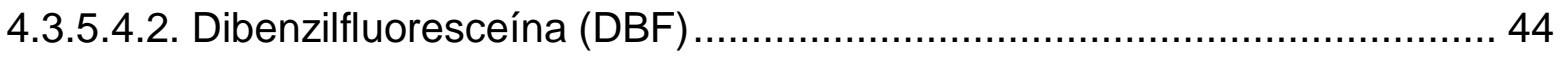

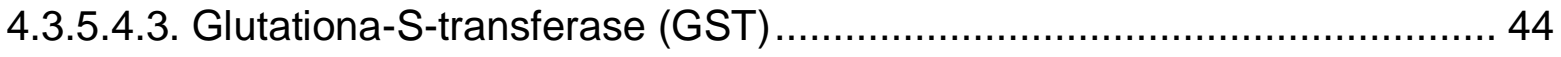

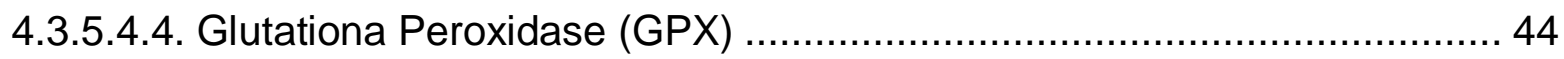

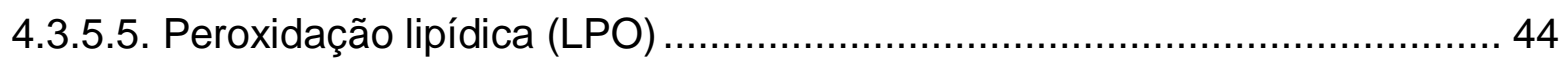

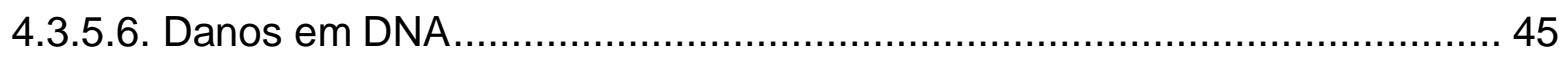

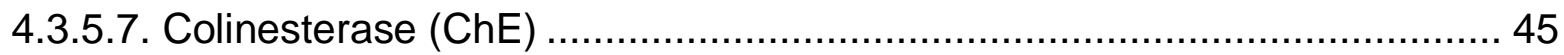

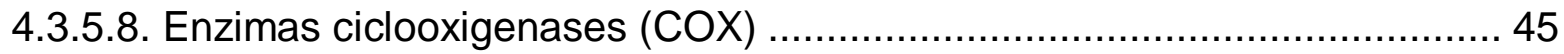

4.3.6. Avaliação dos resultados dos ensaios de toxicidade .................................. 45

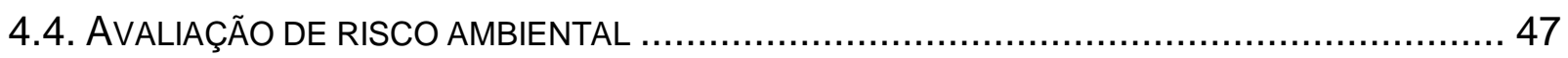

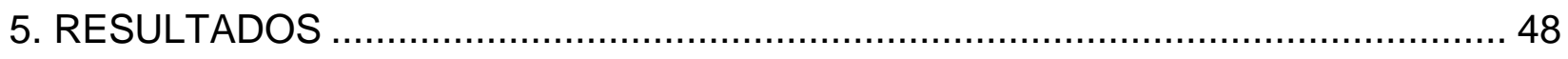

5.1. AVALIAÇÃO ECOTOXICOLÓGICA DOS SEDIMENTOS .............................................. 48

5.1.1. Caracterização sedimentológica............................................................... 48

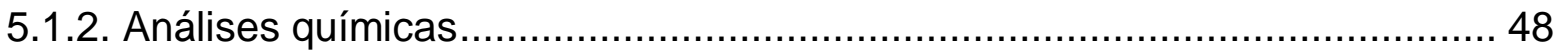

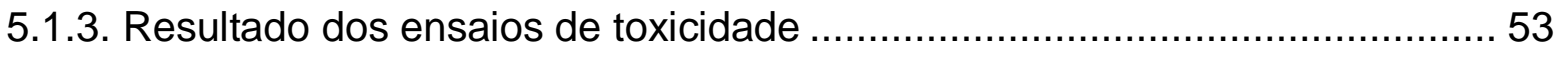

5.1.3.1. Resultado dos ensaios de toxicidade com Perna perna............................ 53

5.1.3.2. Resultado dos ensaios de toxicidade com Lytechinus variegatus............. 60

5.1.3.3. Resultado dos ensaios de citotoxicidade com Mytella charruana.............. 67

5.1.4. Análise de atividades enzimáticas ........................................................ 71

5.1.5. Avaliação de risco ambiental .................................................................. 79

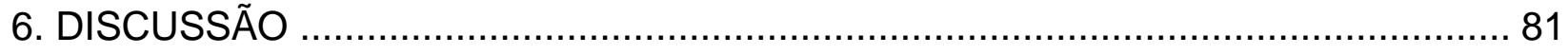

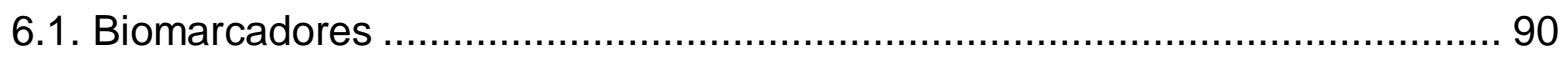

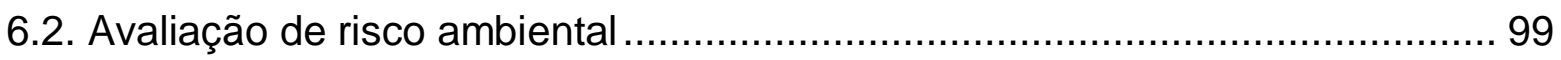

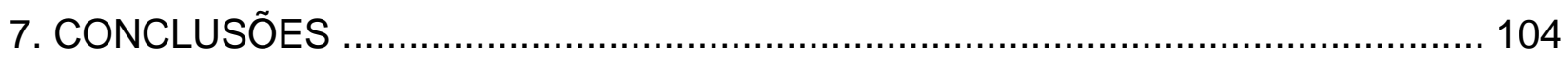

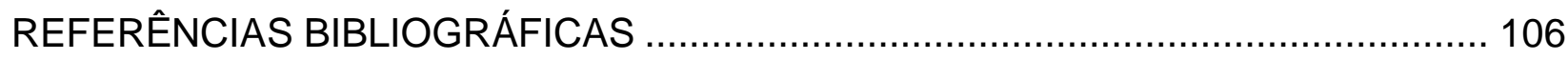




\section{LISTA DE TABELAS}

Tabela 1 - Coordenadas geográficas dos pontos de coleta........................ 25

Tabela 2 - Condições cromatográficas................................................... 30

Tabela 3 - Condições para realização e critérios de aceitabilidade dos ensaios de toxicidade crônica com mexilhão P. perna............................... 32

Tabela 4 - Condições para realização e critérios de aceitabilidade dos ensaios de toxicidade crônica com ouriço-do-mar Lytechinus variegatus... 36 Tabela 5 - Critérios para diferenciação de células saudáveis e estressadas.

Tabela 6 - Caracterização do sedimento (Toque Toque Grande, São Sebastião - SP) de acordo com a escala de Wentworth (1922)

Tabela 7 - Resultados de exatidão observada para os pontos considerados nas curvas analíticas para o triclosan no modo negativo.

Tabela 8 - Resultados de exatidão observada para os pontos considerados nas curvas analíticas para o ibuprofeno no modo negativo.

Tabela 9 - Resultados de exatidão observada para os pontos considerados nas curvas analíticas para o $17 \alpha$-etinilestradiol no modo negativo.

Tabela 10 - Parâmetros de operação MRM no modo de ionização negativo, Limites de detecção, limites de quantificação, tempo de retenção e concentração dos FPCP nas amostras de sedimentos do ESS (ng. $\mathrm{g}^{-1}$ peso seco).

Tabela 11 - Concentrações onde não são previstos efeitos (PNECs) obtidas a partir dos ensaios com ISA (Interface sedimento-água), ELU (Elutriato) e SI (Sedimento integral), e os quocientes de risco (QR) dos compostos detectados no entorno do ESS.

Tabela 12 - Concentrações ambientais do TCS, IBU e EE2 em sedimentos reportadas na literatura. 


\section{LISTA DE FIGURAS}

FIGURA 1 - Origens e rotas dos FPCP (adaptado).

FIGURA 2 - Fluxograma de avaliação de risco ambiental elaborado a partir a da Diretiva da EMEA (2006)

FIGURA 3 - Fluxograma de avaliação de risco ambiental em sedimentos elaborado a partir a da Diretiva da EMEA (2006).

FIGURA 4 - Mexilhões Perna perna.

FIGURA 5 - Ouriço-do-mar L. variegatus.

FIGURA 6 - Tanque com $L$. variegatus.

FIGURA 7 - Mexilhões Mytella charruana.

FIGURA 8 - Triclosan $\left(\mathrm{C}_{12} \mathrm{H}_{7} \mathrm{Cl}_{3} \mathrm{O}_{2}\right)$

FIGURA 9 - Ibuprofeno $\left(\mathrm{C}_{13} \mathrm{H}_{18} \mathrm{O}_{2}\right)$

FIGURA 10 - 17 $\alpha$-Etinilestradiol $\left(\mathrm{C}_{20} \mathrm{H}_{24} \mathrm{O}_{2}\right)$

FIGURA 11 - Localização dos pontos de coleta de sedimentos: A) Posição na América do Sul; B) Ponto controle localizado na praia de Toque Toque Grande/São Sebastião; C) Emissário Submarino de Santos (ESS).

FIGURA 12 - Homogeneizador mecânico de sedimentos do tipo Jarrolling de duas rotações desenvolvido para realização deste estudo.

FIGURA 13 - Sistema de preparação dos testes com interface sedimento-água

FIGURA 14 - Preparo do elutriato com agitador mecânico

FIGURA 15 - Liberação de gametas fêmea.

FIGURA 16 - Coleta de espermatozoides 34

FIGURA 17 - Células saudáveis.

FIGURA 18 - Células estressadas.

FIGURA 19 - Fluxograma com as etapas para o cálculo da CENO e CEO..

FIGURA 20 - Caracterização do risco ambiental elaborado a partir da Diretiva da EMEA. 
FIGURA 21 - Cromatogramas obtidos para TCS, IBU e EE2 no modo negativo.

FIGURA 22 - Representações gráficas da linearidade para os compostos analisados.

FIGURA 23 - Cromatograma obtido no modo de aquisição negativo para a amostra de sedimento do emissário submarino (TCS).

FIGURA 24 - Cromatograma obtido no modo de aquisição negativo para a amostra de sedimento do emissário submarino (IBU)

FIGURA 25 - Resultado dos ensaios de toxicidade do TCS (interface sedimento-água) para o mexilhão $P$. perna após 48 horas de exposição... FIGURA 26 - Resultado dos ensaios de toxicidade do TCS (elutriato) para o mexilhão P. perna após 48 horas de exposição................................ 55

FIGURA 27 - Resultado dos ensaios de toxicidade do IBU (interface sedimento-água) para o mexilhão $P$. perna após 48 horas de exposição... 56 FIGURA 28 - Resultado dos ensaios de toxicidade do IBU (elutriato) para o mexilhão $P$. perna após 48 horas de exposição.

FIGURA 29 - Resultado dos ensaios de toxicidade do EE2 (interface sedimento-água) para o mexilhão $P$. perna após 48 horas de exposição... 58 FIGURA 30 - Resultado dos ensaios de toxicidade do EE2 (elutriato) para o mexilhão $P$. perna após 48 horas de exposição

FIGURA 31 - Resultado dos ensaios de toxicidade do TCS (interface sedimento-água) para $L$. variegatus após 24 horas de exposição.

FIGURA 32 - Resultado dos ensaios de toxicidade do TCS (elutriato) para $L$. variegatus após 24 horas de exposição.

FIGURA 33 - Resultado dos ensaios de toxicidade do IBU (interface sedimento-água) para $L$. variegatus após 24 horas de exposição.

FIGURA 34 - Resultado dos ensaios de toxicidade do IBU (elutriato) para L. variegatus após 24 horas de exposição FIGURA 35 - Resultado dos ensaios de toxicidade do EE2 (interface sedimento-água) para L. variegatus após 24 horas de exposição. 
FIGURA 36 - Resultado dos ensaios de toxicidade do EE2 (elutriato) para L. variegatus após 24 horas de exposição.

FIGURA 37 - Toxicidade do TCS em hemócitos do molusco bivalve Mytella falcata após 24 horas de exposição.

FIGURA 38 - Toxicidade do IBU em hemócitos do molusco bivalve Mytella falcata após 24 horas de exposição.

FIGURA 39 - Toxicidade do EE2 em hemócitos do molusco bivalve Mytella falcata após 24 horas de exposição.

FIGURA 40 - Média e desvio padrão da EROD, DBF, GST, GPX, LPO, ChE, Danos em DNA e COX de brânquias de M. falcata após $24 \mathrm{~h}$ de exposição.

FIGURA 41 - Média e desvio padrão da EROD, DBF, GST, GPX, LPO, ChE, Danos em DNA e COX de glândulas digestivas de M. falcata após 24h de exposição.

FIGURA 42 - Média e desvio padrão da EROD, DBF, GST, GPX, LPO, ChE, Danos em DNA e COX de brânquias de M. falcata após $24 \mathrm{~h}$ de exposição

FIGURA 43 - Média e desvio padrão da EROD, DBF, GST, GPX, LPO, ChE, Danos em DNA e COX de glândulas digestivas de M. falcata após 24h de exposição...

FIGURA 44 - Média e desvio padrão da EROD, DBF, GST, GPX, LPO, ChE, Danos em DNA e COX de brânquias de M. falcata após $24 \mathrm{~h}$ de exposição

FIGURA 45 - Média e desvio padrão da EROD, DBF, GST, GPX, LPO, ChE, Danos em DNA e COX de glândulas digestivas de M. falcata após 24h de exposição. 


\title{
LISTA DE ABREVIATURAS
}

\author{
AINE - Antiinflamatório não-esteroidal \\ CE50 - Concentração de efeito a $50 \%$ dos organismos expostos \\ CEO - Concentração de efeito observado \\ CENO - Concentração de efeito não observado \\ Cl50 - Concentração de inibição a $50 \%$ dos organismos expostos \\ ChE - Colinesterase \\ COX - Ciclooxigenases \\ DBF - Dibenzilfluoresceína \\ DSS - Dodecil Sulfato de Sódio \\ EE2 - 17a-etinilestradiol \\ EFS - Extração em fase sólida \\ ELU - Elutriato \\ ERA - Environmental risk assessment \\ ERO - Espécie reativa de oxigênio \\ EROD - Etoxiresorufina O-deetilase \\ ESS - Emissário submarino de Santos \\ ETE - Estação de tratamento de esgoto \\ ETA - Estação de tratamento de água \\ FPCP - Fármacos e produtos de cuidados pessoais \\ GPx - Glutationa peroxidase \\ GST - Glutationa S-transferase \\ IBU - Ibuprofeno \\ ISA - Interface sedimento-água \\ LPO - Peroxidação lipídica \\ MEC - Mensured environmental concentration \\ MRM - Multiple reaction monitoring \\ PEC - Predicted environment concentration \\ PNEC - Predicted no effect concentration \\ QR - Quociente de risco
}


SI - Sedimento integral

TCS - Triclosan

TRCVN - Tempo de retenção do corante Vermelho Neutro

USEPA - United States Environmental Protect Agency 


\section{INTRODUÇÃO}

Um grande número de xenobióticos potencialmente tóxicos está presente nos ecossistemas dulcícolas e marinhos, muitas vezes em concentrações que por si só não causam efeitos adversos, mas a partir de interações com outras substâncias, podem acarretar danos significativos ao meio ambiente.

Nas últimas décadas há uma crescente preocupação com a presença de compostos químicos emergentes, ou micropoluentes, como fármacos e produtos de cuidados pessoais (FPCP), em ambientes aquáticos e seus possíveis impactos ambientais, pois pouco é conhecido sobre o efeito dessas substâncias no meio ambiente. Nos últimos anos, grande ênfase tem sido dada à avaliação de impactos no meio ambiente a partir de respostas ecotoxicológicas associadas a esses compostos químicos emergentes.

A presença de FPCP no ambiente tem se configurado como um importante tópico das ciências ambientais em fóruns internacionais, pois algumas toneladas de medicamentos e cosméticos são produzidas por ano e aplicadas na medicina humana, veterinária e cuidados pessoais. Estes micropoluentes são desenvolvidos para serem persistentes, mantendo suas propriedades químicas o bastante para servirem a um propósito terapêutico (Mulroy, 2001), o que acarreta em um maior tempo de degradação destes no ambiente. Estudos demonstram que cerca de 50\% a 90\% de uma dosagem de fármaco é excretada de forma inalterada no meio ambiente (Mulroy, 2001) e nele persiste. Estes compostos estão presentes nos ecossistemas aquáticos, sendo os esgotos domésticos, tratados ou não, uma das principais vias de entrada destes compostos.

Até o final do século $X X$, os fármacos e produtos de cuidados pessoais (FPCP) não eram considerados poluentes e não faziam parte dos programas de monitoramento ambiental, devido ao fato destes compostos ocorrerem em concentrações relativamente baixas no ambiente (comparados aos compostos tradicionalmente monitorados), não sendo detectados pelos métodos analíticos disponíveis na época. Porém, o 
desenvolvimento de métodos analíticos mais sensíveis propiciou um aumento significativo do número de estudos ambientais envolvendo fármacos na última década.

A preocupação com a contaminação ambiental por FPCP passou a fazer parte da agenda de governos, especialmente na América do Norte e Europa Ocidental, a partir de estudos demonstrando a feminização de peixes em rios do Reino Unido e Estados Unidos, devido à exposição a substâncias estrogênicas (Harries et al., 1997; Jobling et al., 1998; Hinck et al., 2009), além da demonstração da relação entre eventos de mortalidade em massa de abutres no subcontinente indiano e a ingestão de alimentos com altas concentrações de diclofenaco, uma droga anti-inflamatória (Green et al., 2004). A partir destas e outras evidências de efeitos ambientais importantes associados aos FPCP, especialmente (mas não exclusivamente) sobre a biota aquática, uma vez que corpos aquáticos são destino direto ou indireto destes compostos no ambiente (Arnold et al., 2014), passou a haver uma grande preocupação com o potencial tóxico de compostos antimicrobianos, anti-inflamatórios, anticoncepcionais, antidepressivos e antiepiléticos à biota (USEPA, 2015).

O triclosan (TCS) é uma substância mundialmente utilizada pelo seu mecanismo de efeito antimicrobiano, sendo encontrado em diversos produtos de higiene e cuidados pessoais, como pastas de dente, antissépticos bucais, sabonetes, shampoos, entre outros (USEPA, 2008a). Como consequência, vem sendo encontrado frequentemente em matrizes ambientais como água superficial e sedimentos em concentrações que

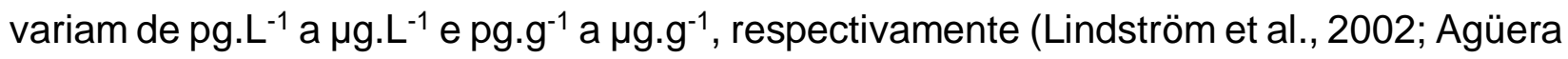
et al., 2003; Xie et al., 2008; Zhao et al., 2010). Além disso, também é encontrado em efluentes industriais e de estações de tratamento de esgoto (ETE), e inclusive em leite materno (Allmyr et al., 2006). Além disso, a fotodegradação do TCS gera como subproduto o dichlorodibenzo-p-dioxin (DCDD) (Lores et al., 2005; Sanchez-Prado et al., 2006), o que aumenta ainda mais a preocupação em relação ao uso intensivo e indiscriminado desta substância.

O ibuprofeno (IBU) é um dos medicamentos mais utilizados no mundo e pertence à classe dos antiinflamatórios não-esteroidais (AINE). A presença de IBU tem sido 
relatada em águas superficiais em uma faixa de concentrações que varia de ng. $\mathrm{L}^{-1}$ a $\mu \mathrm{g} . \mathrm{L}^{-}$ ${ }^{1}$ (Kolpin et al., 2002; Thomas \& Hilton, 2004; Weigel et al., 2004). Carmona et al. (2014), detectaram este composto em sedimentos dulcícolas em concentrações de $30 \mathrm{ng}^{-1} \mathrm{~g}^{-1}$, enquanto Pintado-Herrera e colaboradores (2013), encontraram concentrações de até 100 ng.g ${ }^{-1}$ em sedimentos marinhos na Baía de Cádiz, na Espanha.

Com relação à classe dos hormônios sintéticos, o 17a-etinilestradiol (EE2) é um hormônio estrogênio muito usado em pílulas anticoncepcionais. Sua função se destaca em aumentar o nível da mucosa uterina, construindo um ambiente desconfortável aos espermatozoides e inibindo a síntese dos hormônios ovulátorios. Além do uso contraceptivo, o EE2 é utilizado para tratamento da menopausa e síndrome pósmenopausa, tratamento de câncer de próstata e de mama na pós-menopausa e osteoporose, entre outras doenças (Kuster et al., 2004; Moriyama et al., 2004). O EE2 também é utilizado na aquicultura com o intuito de otimizar o crescimento e desenvolver populações do mesmo sexo, uma vez que a determinação do sexo em peixes pode ser influenciada pela exposição a compostos estrógenos (Kim \& Takemura, 2003; Kuster et al., 2004).

Estudos apontam a presença deste hormônio em concentrações que variam de 3,0 a 34 ng.L-1 em águas superficiais (Zuo et al., 2006; Pojana et al., 2007), e de 9,26 a

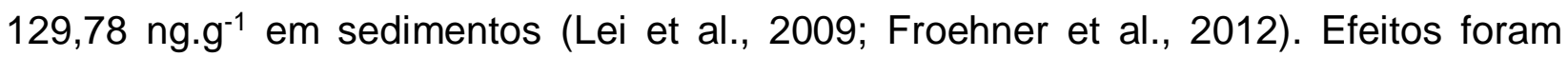
reportados na diminuição da produção de ovos de peixes em concentrações de $10 \mathrm{ng} . \mathrm{L}^{-}$ ${ }^{1}$ (Scholz \& Gutzeit, 2000), estresse oxidativo (LPO) e mortalidade em poliquetas da espécie Hediste diversicolor em concentrações de 0,01 e 10,0 ng.g ${ }^{-1}$ (Maranho et al., 2014).

O triclosan, o ibuprofeno, e 17a-etinilestradiol pertencem às classes de compostos emergentes de maior preocupação das agências de proteção ambiental, como a USEPA e a Environment Canada (USEPA, 2015; Environment Canada, 2011). Estes compostos são constantemente encontrados no ambiente aquático, inclusive em águas superficiais no Brasil (Stumpf et al., 1999; Ghiselli, 2006; Sodré et al., 2007; Moreira et al., 2009;2011; Montagner \& Jardim, 2011, Montagner et al., 2014). 
Apesar de o conhecimento ter avançado sensivelmente no entendimento dos efeitos sobre organismos de água doce (Fent et al., 2006; Arnold et al., 2014; Overturf et al., 2015), atualmente existem relativamente poucos dados sobre os efeitos e o risco ambiental de FPCP em organismos marinhos (Gaw et al., 2014), especialmente organismos bentônicos (Brausch \& Rand, 2011; Aris et al., 2014). Além disso, estudos recentes demonstram a necessidade de estudos sobre a toxicidade crônica e de enzimas envolvidas no sistema antioxidante de invertebrados bentônicos marinhos, a fim de se compreender melhor os mecanismos de estresse oxidativo causado por FPCP (Maranho et al., 2014; Pereira et al., 2016).

Diante deste contexto, e com a tendência de aumento expressivo da população humana em metrópoles costeiras, bem como o aumento da importância da indústria de maricultura com amplo uso de substâncias farmacêuticas, aliado às evidências já existentes da presença destes compostos em sedimentos marinhos costeiros ao redor do mundo (Arpin-Pont et al., 2016), considera-se que há uma eminente necessidade de investigar o risco ambiental de FPCP em ambientes costeiros em geral, especialmente em organismos expostos a sedimentos contaminados, visto que trata-se do destino, direta ou indiretamente, dessas substâncias no ambiente.

Nesse sentido, o presente estudo partiu das seguintes hipóteses: 1) A ocorrência dos FPCP triclosan (TCS), ibuprofeno (IBU) e 17a-etinilestradiol (EE2) em sedimentos pode causar efeitos em diferentes níveis de organização biológica de invertebrados marinhos; 2) A presença de FPCP em sedimentos representa risco para invertebrados marinhos bentônicos.

O presente estudo avaliou o risco ambiental de substâncias farmacêuticas amplamente utilizadas (TCS, IBU e EE2), empregando invertebrados marinhos expostos a sedimentos contaminados. Para tal, foi inicialmente estimada a exposição da biota a estas substâncias, a partir de concentrações ambientais obtidas de sedimentos provenientes das imediações do emissário submarino de esgoto da Baía de Santos, litoral de São Paulo, Brasil. Em seguida, foram avaliados os efeitos destes compostos em diferentes níveis de organização biológica com diferentes organismos marinhos por meio 
de uma bateria de bioensaios. Por último, seguindo a avaliação de risco ambiental da EMEA (2006), foi estimado o quociente de risco para cada um dos compostos estudados. Este estudo representa a primeira avaliação de risco de FPCP em sedimentos de ambientes costeiros brasileiros, e busca contribuir para o conhecimento dos riscos ambientais destes compostos em ecossistemas marinhos tropicais, uma vez que estudos desta natureza são escassos nestes ambientes. 


\section{OBJETIVOS}

O presente estudo avaliou o risco ambiental do triclosan, ibuprofeno e 17aetinilestradiol em sedimentos, por meio da identificação das concentrações ambientais destes compostos na baía de Santos, e de ensaios de toxicidade e uso de biomarcadores para avaliação de efeitos em diferentes níveis de organização biológica de invertebrados marinhos.

\subsection{Objetivos específicos}

> Avaliar as concentrações ambientais do TCS, IBU e EE2 em amostras de sedimentos da área de influência do Emissário Submarino de Santos (ESS);

> Avaliar os efeitos crônicos de sedimentos contaminados com TCS, IBU e EE2 no desenvolvimento embriolarval de mexilhões (Perna perna) e ouriços-do-mar (Lytechinus variegatus);

> Elucidar as vias metabólicas de biotransformação (Fases I e II) e de enzimas antioxidantes de mexilhões Mytella charruana expostos a sedimentos marcados com TCS, IBU e EE2, assim como avaliar os efeitos cito-genotóxicos a partir da estabilidade da membrana lisossômica, peroxidação lipídica, danos em DNA (strand break), de efeitos neurotóxicos (colinesterase), e enzimas cicloxigenases;

$>$ Avaliar o risco ambiental de sedimentos marinhos contaminados com TCS, IBU e EE2. 


\section{REVISÃO BIBLIOGRÁFICA}

\subsection{Baixada Santista}

As regiões costeiras, de uma maneira geral, tendem a apresentar uma intensa ocupação humana, ocasionando forte pressão sobre os ecossistemas que aí se encontram. No Brasil, das 25 regiões metropolitanas, 14 encontram-se em estuários onde se localizam os principais polos petroquímicos e sistemas portuários do país, responsáveis por uma significativa degradação destes ecossistemas.

O Sistema Estuarino de Santos e de São Vicente, inserido na Região Metropolitana da Baixada Santista, Estado de São Paulo $\left(23^{\circ} 30^{\prime}\right.$ S- $24^{\circ} \mathrm{S}$ e $46^{\circ} 5^{\prime} \mathrm{W}$ $\left.46^{\circ} 30^{\prime} \mathrm{W}\right)$, representa um dos mais importantes exemplos brasileiros de degradação ambiental por poluição hídrica e atmosférica de origem industrial e portuária em ambientes costeiros. A região abriga o maior porto da América Latina (o Porto de Santos) e um dos maiores polos industriais do país, situado em Cubatão (Lamparelli et al., 2001).

Essas atividades, de alto potencial poluidor, fizeram dos estuários de Santos e São Vicente grandes receptores de resíduos tóxicos e efluentes líquidos contaminados. Os poluentes industriais, juntamente com os resíduos de esgoto do Porto de Santos e das cidades da região, provocaram um grave quadro de degradação ambiental, com significativos reflexos na área social e de saúde pública. Este cenário foi agravado, ainda, pela disposição de resíduos sólidos industriais e domésticos em locais impróprios, além dos frequentes acidentes com derramamentos de óleo e outras substâncias tóxicas nos cursos d'água, tendo sido o estuário de Santos considerado como um dos mais poluídos do mundo nas décadas de 1970 e 1980 (TOMMASI, 1979).

Diante deste cenário, a Companhia Ambiental do Estado de São Paulo (CETESB), entre outros pesquisadores realizaram diversos estudos para avaliação da qualidade ambiental e para se minimizar os impactos na região. Como consequência, o sistema estuarino de Santos já está relativamente bem estudado quanto a vários aspectos, principalmente relacionados à presença de poluentes orgânicos e metais, e estudos ecotoxicológicos com amostras de água e sedimentos com diferentes organismos-teste 
(Tommasi, 1979; Abessa 1996; 2002; Lamparelli et al., 2001; Rachid, 2002; Cesar et al., 2006; 2007; Pusceddu et al., 2007; Souza et al., 2007; Ferraz, 2013; Choueri et al., 2009).

Em 2014, Souza e colaboradores realizaram uma revisão de todos os estudos ecotoxicológicos realizados na região no período entre 1996 e 2011, num total de 51 estudos (Souza et al., 2014), mas a questão da contaminação ambiental por FPCP foi pouco estudada, principalmente no que se refere à contaminação de sedimentos.

\subsection{Fármacos no ambiente}

A presença de PPCP nos ecossistemas brasileiros têm se configurado como importante tópico nos fóruns de pesquisa nacionais e vêm sendo reportado em um número cada vez maior de estudos ambientais. Dentre as principais causas do aumento dos FPCP no ambiente estão a automedicação, desinformação, falta de regulamentação, medicamentos fracionados, aumento no número de farmácias e drogarias, crescimento da população idosa devido aos avanços da medicina e a implantação de remédios genéricos. A Figura 1 apresenta as principais rotas dos fármacos no ambiente aquático. 


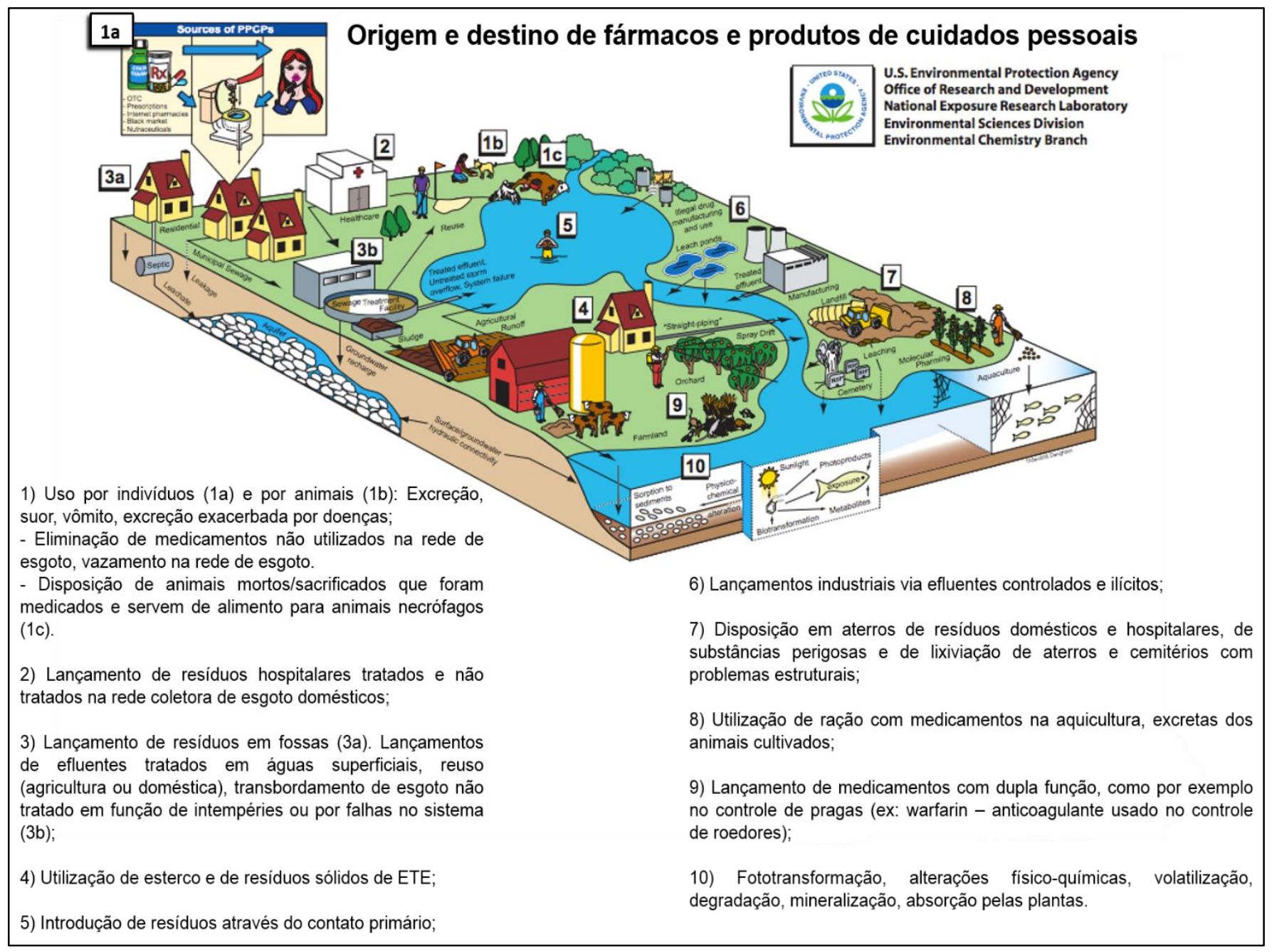

FIGURA 1 - Origens e rotas dos FPCP (adaptado). Fonte: USEPA

De acordo com Petrie et al. (2015), a principal via de entrada dos FPCP no ambiente aquático são os esgotos domésticos. Stumpf e colaboradores (1999), encontraram diversos anti-inflamatórios em quantidades que variaram de 0,1 a $1 \mu \mathrm{g} . \mathrm{L}^{-1}$ no efluente de ETE lançado no rio Paraíba do Sul, Rio de Janeiro. Em estudo realizado nas águas superficiais da Região Metropolitana de Campinas, na bacia do rio Atibaia, Ghiselli (2006) observou a presença de diversos FPCP e interferentes endócrinos como, por exemplo, diclofenaco $\left(2,0-6,0 \mu \mathrm{g} \cdot \mathrm{L}^{-1}\right)$, estradiol $\left(1,9-6,0 \mu \mathrm{g} \cdot \mathrm{L}^{-1}\right)$, etinilestradiol $(1,2$ $\left.-3,5 \mu \mathrm{g} \cdot \mathrm{L}^{-1}\right)$ e bisfenol $\mathrm{A}\left(2,2-64,2 \mu \mathrm{g} \cdot \mathrm{L}^{-1}\right)$. Além disso, foi detectada a presença destes compostos inclusive nas águas de abastecimento público da região. 
Gerolin (2008) analisou a eficiência da estação de tratamento de água (ETA) de Campinas para a remoção de alguns desruptores endócrinos, e observou aproximadamente $60 \%$ de redução nas concentrações de $17 \alpha$-etinilestradiol, onde a ocorrência foi de $444 \mathrm{ng} \cdot \mathrm{L}^{-1}$ em água bruta e $275 \mathrm{ng} \cdot \mathrm{L}^{-1}$ após o tratamento. Ainda na Região Metropolitana de Campinas, Sodré et al. (2007) detectou 17ß-estradiol (0,038 $\left.2,5 \mu \mathrm{g} \cdot \mathrm{L}^{-1}\right)$ e $17 \alpha$-etinilestradiol $\left(0,006-0,3 \mu \mathrm{g} \cdot \mathrm{L}^{-1}\right)$, entre outros compostos, enquanto Montagner e Jardim (2011) determinaram diclofenaco (106 ng.. $\left.{ }^{-1}\right)$, paracetamol $(13,4$ $\left.\mu g \cdot L^{-1}\right)$ e $17 a$-etinilestradiol $\left(4,3 \mu g \cdot L^{-1}\right)$.

Ainda no Estado de São Paulo, Montagner e colaboradores (2014) detectaram triclosan em águas superficiais em concentrações que variaram de 2,2 a $66 \mathrm{ng} . \mathrm{L}^{-1}$. Já em Minas Gerais, foram detectados hormônios naturais (17ß-estradiol) e sintéticos (17aetinilestradiol) em águas superficiais, em concentrações que variam de 1,5 a 62,6 ng. L-1 e 3,0 a 63,8 ng.L-1 , respectivamente (Moreira et al., 2009; 2011).

Recentemente em um estudo paralelo a este, Pereira e colaboradores (2016) analisaram águas superficiais e de fundo no entorno do lançamento de esgoto pelo emissário submarino de Santos, SP, e evidenciaram pela primeira vez a presença fármacos e drogas ilícitas em águas marinhas no litoral do Brasil. Foram detectadas a presença de acetaminofeno (34,6 ng. L-1 $)$, losartan $\left(32,0 \mathrm{ng} \cdot \mathrm{L}^{-1}\right)$, valsartan $\left(75,0 \mathrm{ng} \cdot \mathrm{L}^{-1}\right) \mathrm{e}$ diclofenaco (19,4 ng. $\left.\mathrm{L}^{-1}\right)$, além de cocaína $\left(537,0 \mathrm{ng} \cdot \mathrm{L}^{-1}\right)$. O ibuprofeno foi detectado em todas as amostras analisadas em concentrações que variaram de 326,1 até 2094,4 ng.L' 1.

No que se refere à contaminação de sedimentos no Brasil, Beretta e colaboradores (2014) detectaram compostos como ibuprofeno (18,8 $\left.\mathrm{ng} \cdot \mathrm{g}^{-1}\right)$, carbamazepina $\left(4,81 \mathrm{ng} \cdot \mathrm{g}^{-}\right.$ $\left.{ }^{1}\right)$ e diclofenaco $\left(1,06 \mathrm{ng} \cdot \mathrm{g}^{-1}\right)$ nos sedimentos da Baia de Todos os Santos, na Bahia. Froehner e colaboradores (2012) encontraram 17a-etinilestradiol em sedimentos de manguezais em altas concentrações, que variaram de 0,11 a $129,78 \mathrm{ng} \cdot \mathrm{g}^{-1}$.

O aumento da ocorrência de FPCP no ambiente aquático pode causar efeitos adversos à saúde humana e às comunidades aquáticas. O risco ambiental dos FPCP 
juntamente com a proliferação do uso de compostos orgânicos sintéticos desencadeou uma grande preocupação com o potencial tóxico para a biota aquática.

Embora os FPCP venham sendo reportados em um número cada vez maior de estudos no Brasil, pouco se conhece sobre as concentrações ambientais destes compostos em ecossistemas marinhos, bem como nos sedimentos e seus efeitos sobre invertebrados bentônicos.

\subsection{Ecotoxicologia e meio ambiente}

A necessidade de se conhecer os efeitos causados pelos xenobióticos nos ecossistemas marinhos tem levado ao desenvolvimento de diversos métodos destinados à avaliação dos efeitos biológicos da poluição. Estes métodos, em conjunto com análises químicas, têm sido utilizados em um número cada vez maior de estudos ambientais. Esses estudos surgiram para complementar a abordagem da contaminação química nos programas de monitoramento ambiental, realizadas pelas análises químicas, com 0 desenvolvimento de uma avaliação da poluição com ênfase nos efeitos biológicos (Moore et al., 1987; Bayne et al., 1988).

Nesse sentido, a Ecotoxicologia, ciência que estuda os contaminantes e seus efeitos nos constituintes da biosfera, tem sido utilizada com o propósito de se conhecer e avaliar os impactos das atividades humanas no ambiente, uma vez que aborda efeitos tóxicos em níveis celulares (bioquímico e fisiológico), individual, e até níveis mais elevados de organização, como populacional, de comunidade, ecossistemas e biosfera (Newman \& Unger, 2003).

Dentro da Ecotoxicologia, os ensaios de toxicidade são consagrados como importantes métodos de controle ambiental, fornecendo dados qualitativos e quantitativos sobre os efeitos adversos de contaminantes (Cooney, 1995), proporcionando uma evidência direta das consequências da contaminação, podendo ser utilizada para estimar a toxicidade de misturas complexas em diferentes matrizes ambientais (Cesar et al., 2002). Vale ressaltar que alguns parâmetros analisados nos ensaios de toxicidade, como efeito agudo e crônico, estão contemplados na legislação brasileira, por meio da 
Resolução CONAMA № 430/11 (BRASIL, 2011) que complementa e altera a Resolução CONAMA no 357/05 (BRASIL, 2005a), e também em diversos protocolos para avaliação de risco ambiental e regulação de concentrações de compostos no ambiente aquático.

Os ensaios de toxicidade são procedimentos nos quais as respostas de organismos vivos são utilizadas para avaliar a capacidade de substâncias químicas e amostras ambientais de causar efeitos deletérios sobre os organismos expostos (Rand et al., 1995), podendo estimar, por meio de relações matemáticas, os efeitos da poluição em níveis de organização biológica elevados, como populações e comunidades.

A avaliação de efeitos em níveis menores de organização biológica, como efeitos crônicos ou sub-crônicos, causados pela exposição de organismos a baixas concentrações de poluentes no ambiente aquático, tem sido realizada com o uso de biomarcadores. A utilização de biomarcadores bioquímicos e moleculares é de grande importância no monitoramento e prognóstico de impacto ambiental, uma vez que as alterações detectadas indicam distúrbios ambientais antes que os mesmos atinjam níveis de organização biológica elevados e irreversíveis (Moore, 1988).

Walker et al. (1996) define biomarcadores como indicadores bioquímicos, fisiológicos ou histológicos de exposição ou efeito de xenobióticos presentes no ambiente, em nível de organismo ou de "sub-organismo". Suas respostas podem ser utilizadas como sinal prévio de efeitos tóxicos, uma vez que o ponto de partida de todos os danos causados por xenobióticos envolve perturbações de processos bioquímicos e moleculares no interior das células, posteriormente dando origem aos efeitos em níveis maiores de organização (Cheung et al., 1997).

Dentre os diferentes biomarcadores usados, o ensaio de avaliação do tempo de retenção do corante Vermelho Neutro em hemócitos de moluscos e crustáceos tem sido utilizado a fim de se detectar alterações na permeabilidade de membranas lisossômicas, que podem ocorrer em função da exposição a contaminantes. Os lisossomos são organelas que desempenham importante função em uma grande variedade de processos fisiológicos que incluem: digestão intracelular, reparo celular e respostas imunológicas, entre outras. Devido sua capacidade de acumular uma grande variedade de substâncias 
orgânicas e inorgânicas, essas organelas têm sido identificadas como "alvos" dos efeitos deletérios causados por diferentes contaminantes (Hwang et al., 2002). Assim, devido à sua alta sensibilidade a diversos grupos de contaminantes e provável extrapolação dos danos lisossomais para níveis maiores de organização biológica (indivíduo/população), a integridade da membrana lisossômica tem sido amplamente utilizada como biomarcador de estresse químico.

Enzimas envolvidas nos processos de biotransformação de fase I e I| de xenobióticos também vêm sendo amplamente utilizadas como biomarcadores em diversos estudos ambientais, uma vez que desempenham um papel crucial na manutenção da homeostase celular, e sua utilização tem sido proposta como indicadores de exposição a contaminantes em uma grande variedade de organismos marinhos (Winston, 1991).

A atividade da EROD pode ser induzida pela presença de vários compostos orgânicos e tem sido empregada como um indicativo de detoxificação por enzimas relacionadas a famílias do Citocromo P450 (CYP 450), uma vez que é responsável pela fase I de biotransformação de compostos lipofílicos, como os FPCP. Além do processo de biotransformação dos compostos pela EROD, cinco classes de CYP 450 (P4501A2, 2C9, 2C19, 2D6, e 3A4) participam do metabolismo de fármacos em mamíferos (Crespi et al., 1997) e duas delas (2C9 e 3A4) representam as principais isoenzimas no metabolismo desses compostos (Stresser et al., 2000). Gagné et al. (2007) utilizaram a Dibenzilfluoresceína (DBF) como substrato para determinação da atividade de CYP 450 3A-like em bivalves como indicador de exposição a fármacos.

A eliminação de moléculas polares, algumas das quais ocorrem a partir da fase I de biotransformação, é seguida por conjugação pela família de enzimas Glutationa-STransferase (GST). A atividade da enzima GST vem sendo amplamente utilizada como indicadora de exposição à FPCP em organismos aquáticos. A GST faz parte da segunda fase de reações do metabolismo de detoxificação e tem como função promover a conjugação de compostos endógenos e xenobióticos biotransformados com o tripeptídeo glutationa, tornando-os mais hidrossolúveis e, portanto, mais facilmente excretados. Sua 
distribuição tem sido reportada para todas as espécies de animais, encontrando-se preferencialmente solubilizada no citosol (Dauterman, 1994).

Já as alterações no sistema de defesa antioxidante dos organismos aquáticos podem ser reflexo de um aumento na síntese de espécies reativas de oxigênio (ERO) induzido pela exposição à contaminantes, associado a uma situação de estresse oxidativo, quando os mecanismos de defesa são sobrepostos pelas forças pró-oxidantes (Bainy,1995). Alterações no sistema de defesa antioxidantes podem ser mensuradas por meio da Glutationa Peroxidase (GPX), que possui reconhecida função na prevenção de efeito oxidativo. Se esses mecanismos forem sobrepostos, podem ocorrer efeitos adversos como peroxidação lipídica (LPO), degradação de proteínas e danos em DNA, entre outros (Cheung et al., 2001). O processo de lipoperoxidação, ou oxidação de lipídios, ocorre por uma cadeia de reações, iniciada pela abstração de um átomo de hidrogênio de um grupo metil (- $\mathrm{CH} 2$ ) de um ácido graxo poli-insaturado e, neste sentido, possui grande potencial como biomarcador de efeito oxidativo.

A exposição a compostos genotóxicos pode ser avaliado por meio dos níveis de danos em DNA, uma vez que alteram diretamente a integridade da estrutura do DNA, ou de seus metabólitos (Shugart, 1995). Os danos incluem quebras de cadeias simples e dupla, bases modificadas, ligações cruzadas de DNA-DNA, e ligações cruzadas de DNAproteína. As quebras de cadeia também podem ser induzidas indiretamente pela interação com radicais livres, pela ação de enzimas de reparação por excisão, e como consequência de processos de apoptose ou necrose (Speit \& Hartmann, 1995).

Estudos demonstram a necessidade do uso de diferentes biomarcadores de forma concomitante para avaliação dos primeiros sinais de efeito. A integração dos diferentes resultados de biomarcadores pode esclarecer os mecanismos tóxicos e a biodisponibilidade dos contaminantes sobre a biota aquática (Aguirre-Martínez et al., 2013a; Maranho et al., 2014; Pereira et al., 2014). 


\subsection{Legislação}

A legislação brasileira tem tido grande avanço nas questões ambientais nos últimos anos, principalmente no que se refere ao ambiente aquático, no qual os instrumentos legais tornaram-se explícitos quanto ao controle ecotoxicológico de efluentes industriais, por meio da Resolução CONAMA no 430/2011, que complementa e altera a Resolução CONAMA no 357/2005 (Brasil, 2005a; 2011).

No que diz respeito à qualidade dos sedimentos, o único documento legal no Brasil que se refere à contaminação de sedimentos é a Resolução CONAMA № 454/2012 (Brasil, 2012), que instituiu a complementação de análises ecotoxicológicas na avaliação do material dragado de corpos d'água doce, salina e salobra.

Com relação aos FPCP, a Resolução CONAMA 358/2005 (Brasil, 2005b) e a Resolução RDC 306/2004 (Anvisa, 2004) dispõe sobre o descarte de resíduos dos serviços de saúde, incluído a destinação adequada dos produtos farmacêuticos, a qual não é específica, ficando a critério de quem produz qual o tratamento e descarte adequado. Uma vez comercializados, os produtos são descartados sem controle. $\mathrm{Na}$ Baixada Santista, a Lei complementar ํㅡ 840, da Prefeitura Municipal de Santos, trata do descarte de medicamentos em hospitais, postos de saúde, farmácias e estabelecimentos similares, os quais deverão prover uma urna para recolhimento de medicamentos inservíveis (CMS, 2014).

$\mathrm{Na}$ União Europeia, os testes de toxicidade para registro de fármacos foram inicialmente requeridos pela Diretiva 92/18 EEC e pela correspondente Note for Guidance (EMEA, 1998). De acordo com a Diretiva 2001/83/EC do Parlamento Europeu, posteriormente alterada pela diretiva 2004/27/CE, a solicitação para autorização de registro de um novo produto medicinal deve ser acompanhada da avaliação de risco ambiental (EMEA, 2006). 


\subsection{Avaliação de risco}

O estabelecimento do risco ambiental relativo aos FPCP em sistemas aquáticos constitui uma tarefa complexa, uma vez que são escassas ou ausentes informações importantes que permitam avaliar de forma robusta o comportamento e efeito destes compostos no ambiente aquático em geral e, principalmente, no ambiente marinho.

Os procedimentos para a avaliação de risco ambiental de produtos farmacêuticos são empregados para fins reguladores na União Europeia, e requerem dados adequados sobre a exposição ambiental e os efeitos ecotoxicológicos dos compostos farmacêuticos ativos.

Instrumentos reguladores Europeus, tais como o "Note for Guidance" (NfG) (EMEA/CHMP/SWP/4447/00) publicado pela Agência Europeia de Medicamentos (EMEA, 2006), o Documento Guia Técnico (TGD) na Diretiva de Apoio de Comissões 93/67/EEC de Avaliação de Risco Ambiental para as Novas Substâncias Notificadas, e as Comissões Reguladoras (EC) No. 1488/94 sobre a Avaliação de Risco de Substâncias Existentes (EC, 2003), descrevem um processo de avaliação de risco ambiental escalonado em diferentes etapas, que inicia com estimações preliminares e avança até métodos mais refinados se o risco potencial não puder ser excluído. Importante salientar que tal avaliação pode finalizar tanto quando exista suficiente informação disponível que indique que o produto/composto não represente um risco ambiental, como quando o risco seja identificado e suficientemente caracterizado.

A EMEA (European Medicines Agency), responsável pela proteção da saúde animal e pública através da investigação científica e supervisão de medicamentos, publicou a diretiva EMEA/CHMP/SWP/4447/00 que descreve recomendações para a avaliação de risco ambiental de medicamentos de uso humano (EMEA, 2006). Esse guia leva em consideração diferentes dados, como concentrações ambientais mensuradas ou estimadas, resultados de ensaios de toxicidade com diferentes organismos, características químicas dos compostos analisados e fatores de avaliação, que são expressões do grau de incerteza na extrapolação dos dados dos ensaios de toxicidade com um número relativamente limitado de espécies quando comparado ao ambiente 
natural. Além disso, o fator de avaliação considera variações nas diferenças de sensibilidade interespécies, na variabilidade intraespécies, e a extrapolação de dados gerados em laboratório para o ambiente natural.

A avaliação de risco proposta pela EMEA (2006) é dividida basicamente em duas fases. A Fase I, considerada "pre-screening", consiste na determinação (Mensured environmental concentration - MEC) ou estimativa (Predicted enviromental concentration - PEC) das concentrações ambientais dos compostos estudados. Quando a concentração do composto no ambiente for maior que 0,01 $\mu \mathrm{g} / \mathrm{L}$, deve ser realizada avaliação de risco ambiental - Fase II. Em alguns casos, esse limite não precisa ser aplicado, pois alguns fármacos podem afetar a reprodução de vertebrados ou invertebrados em concentrações mais baixas do que 0,01 $\mu \mathrm{g} / \mathrm{L}$. Neste caso, estas substâncias devem entrar diretamente na Fase II da estratégia de avaliação de risco. Vale ressaltar que a avaliação de risco de compostos altamente lipofílicos e potenciais desreguladores endócrinos podem ser realizadas independentemente da quantidade liberada no ambiente.

A Fase ll é dividida em duas etapas, denominadas TIER A e B. No TIER A, é feito o levantamento de um conjunto de dados, que prevê informações sobre as propriedades físico-químicas, o destino da substância no ambiente, e os efeitos em organismos aquáticos. Nesta avaliação, são propostos ensaios de toxicidade crônica para se determinar concentrações onde não são previstos efeitos (Predicted no effect concentration - PNEC), com o objetivo de prever a concentração da substância para a qual não se espera que ocorram efeitos adversos.

Se a relação entre a concentração ambiental e a concentração onde não são previstos efeitos (PEC ou MEC / PNEC) do fármaco apresentar quociente de risco (índice para o estabelecimento do risco ambiental) inferior a 1, pode-se concluir que a substância não é susceptível de representar risco para o ambiente aquático. Se a relação for superior a 1, serão necessárias avaliações mais robustas no TIER B. 
O TIER B trata-se de uma avaliação de risco detalhada, com avaliações mais aprofundadas, e pode ser realizada por meio de um PEC mais preciso ou da concentração ambiental mensurada (MEC), da PNEC do composto de origem, e de outros dados relevantes, como efeitos biológicos específicos por meio do uso, por exemplo, de biomarcadores. Um esquema da metodologia de avaliação de risco ambiental é apresentado na Figura 2.

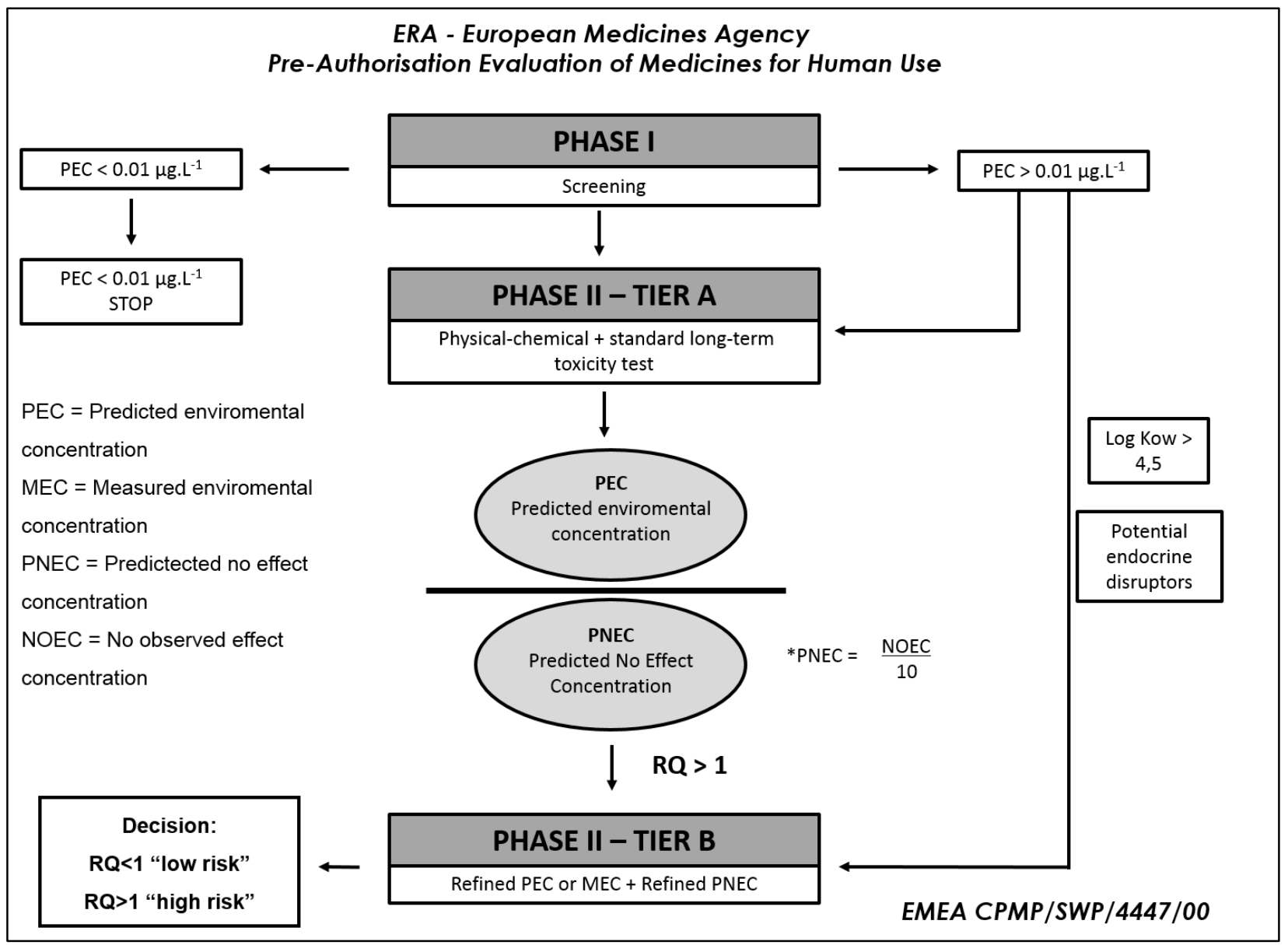

FIGURA 2 - Fluxograma de avaliação de risco ambiental elaborado a partir a da Diretiva da EMEA (2006).

O destino de substâncias que não são facilmente biodegradáveis deve ser investigado em estudos com sedimentos no TIER B, onde são considerados os efeitos em organismos que vivem associados a esse compartimento. O critério para estudos de sedimentos é atendido se mais que $10 \%$ da substância encontra-se presente no ambiente durante um período igual ou superior a 14 dias. Para avaliação de risco de sedimentos contaminados com fármacos, devem ser analisados efeitos sobre organismos bentônicos 
e posteriormente comparados com as concentrações ambientais no sedimento. De acordo com a EEA (2010), os dados obtidos a partir de avaliações de risco ambiental de produtos farmacêuticos, mostrou que $95 \%$ dos produtos farmacêuticos aplicados não são facilmente biodegradáveis. Dos medicamentos de uso humano avaliados, 15\% foram persistentes em água e 50\% no sedimento. Um esquema da metodologia de avaliação de risco ambiental em sedimentos é apresentado na Figura 3.

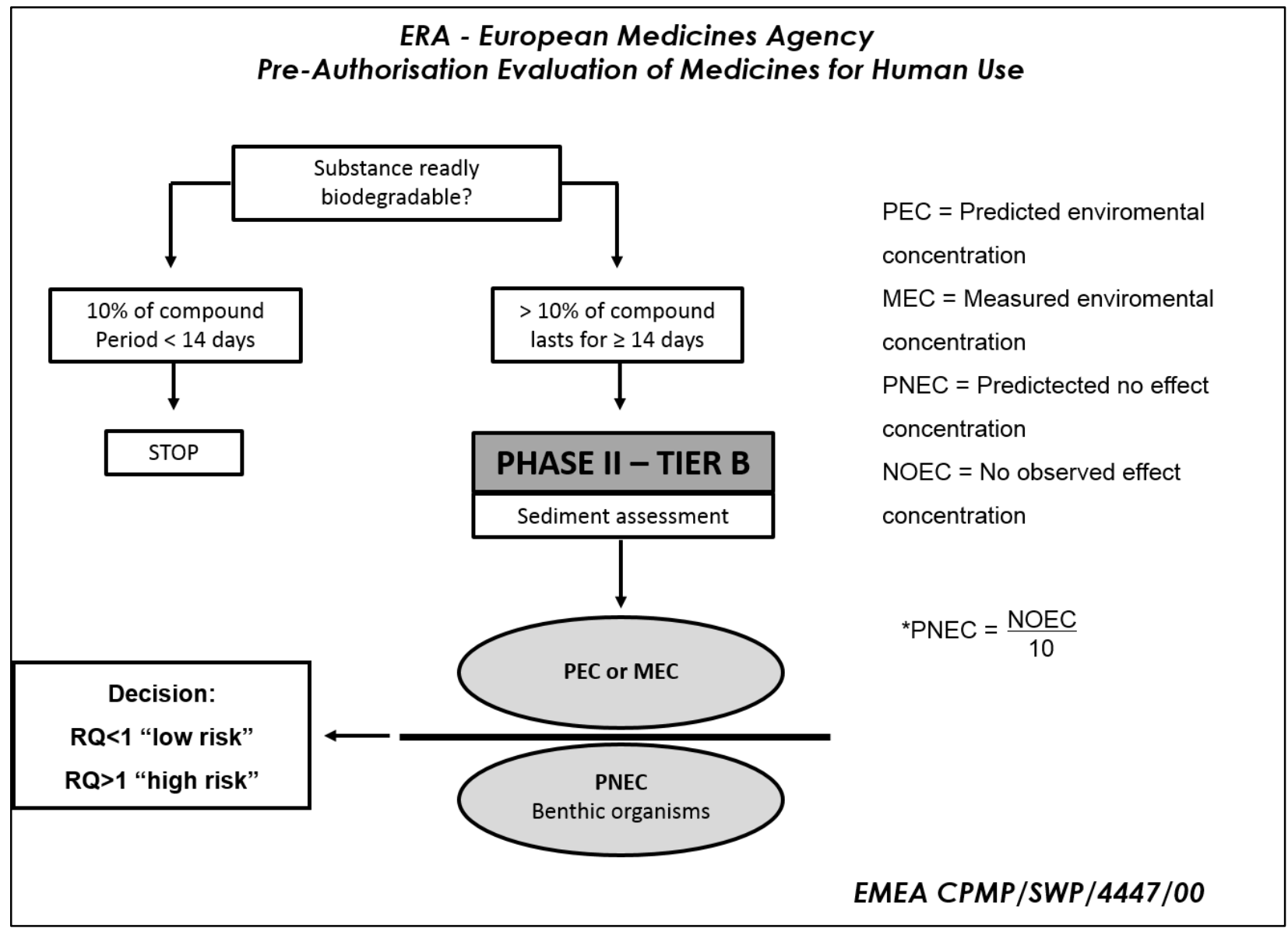

FIGURA 3 - Fluxograma de avaliação de risco ambiental em sedimentos elaborado a partir a da Diretiva da EMEA (2006).

A importância de avaliar os riscos ambientais de compostos químicos emergentes é refletida em um dos objetivos "top cinco" da estratégia da Agência de Proteção Ambiental Norte Americana (USEPA). A identificação precoce e a investigação de possíveis problemas de poluição ambiental relacionada aos FPCP são de suma importância para proteção da saúde humana e ambiental. 


\section{MATERIAIS E MÉTODOS}

\subsection{Coleta, manutenção e cultivo de organismos-teste}

\subsubsection{Mexilhão Perna perna}

Os mexilhões da espécie Perna perna (Figura 4) utilizados nos experimentos para avaliação de efeito crônico dos compostos foram adquiridos de cultivos na praia de Toque Toque Grande, localizada no município de São Sebastião, litoral de São Paulo. Os organismos foram mantidos em caixa térmica durante o transporte até o laboratório, onde foram mantidos em tanques com água do mar e aeração constante até o momento da realização dos ensaios. Antes de iniciar o estudo, todos os indivíduos coletados foram limpos de organismos incrustantes.

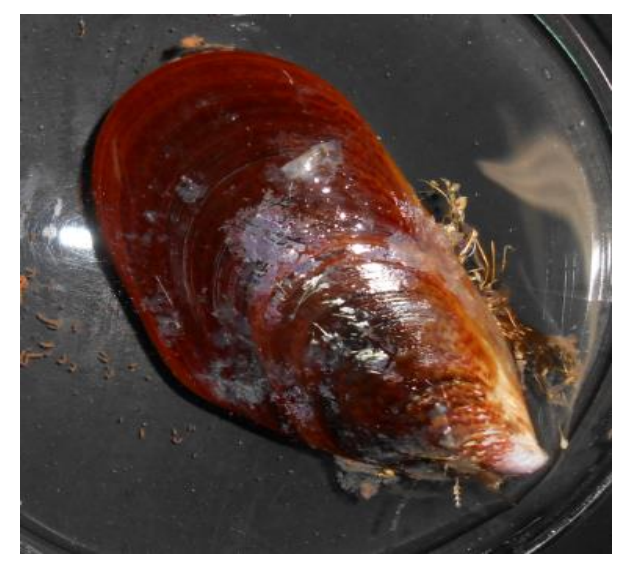

FIGURA 4 - Mexilhões Perna perna.

\subsubsection{Ouriço-do-mar Lytechinus variegatus}

Os ouriços-do-mar L. variegatus (Figura 5) utilizados nos ensaios de toxicidade para avaliação de efeito crônico foram coletados por meio de mergulho livre na costa de São Sebastião, SP. Os organismos foram transportados em caixa térmica, recobertos com algas coletadas no mesmo local, até a chegada ao laboratório. Em laboratório os organismos foram mantidos em tanques com água do mar e aeração até o momento da realização dos ensaios (Figura 6). 


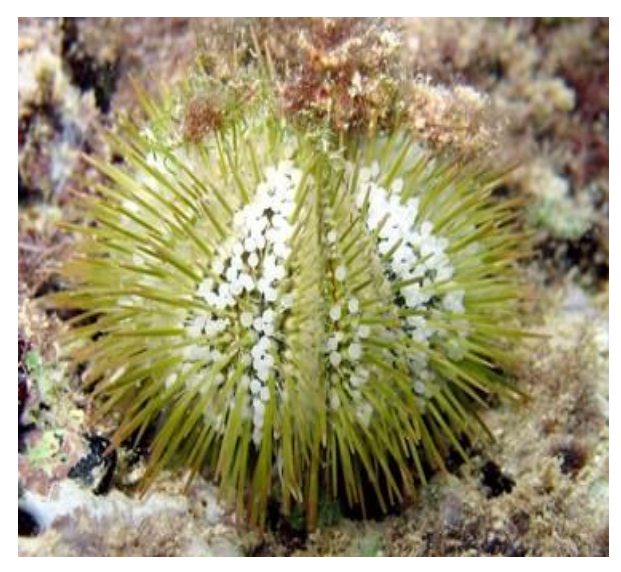

FIGURA 5 - Ouriço-do-mar L. variegatus.

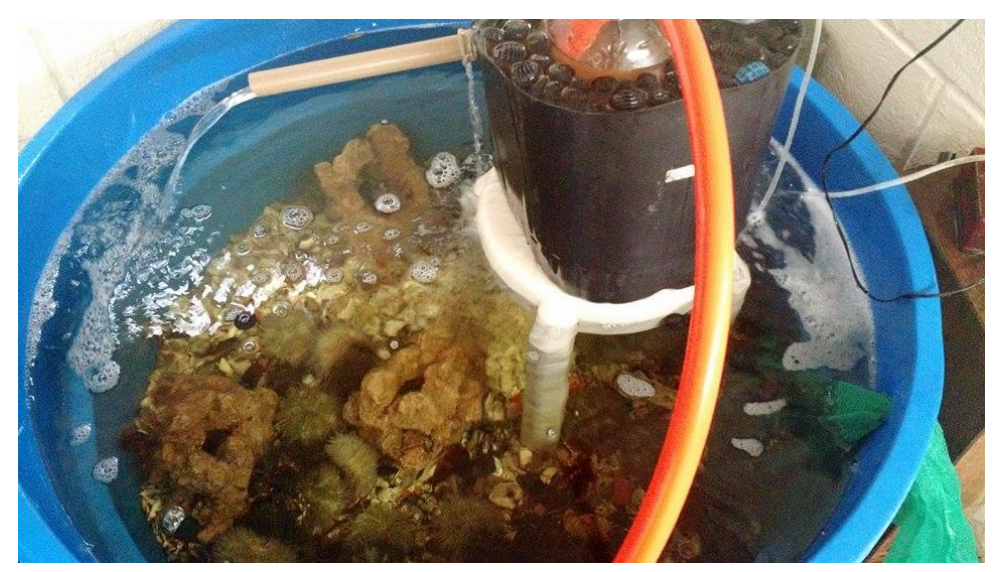

FIGURA 6 - Tanque com L. variegatus.

\subsubsection{Mexilhão Mytella charruana}

Os mexilhões da espécie Mytella charruana (Figura 7) utilizados no presente estudo foram coletados em Bertioga, litoral de São Paulo. Os organismos foram mantidos em caixa térmica durante o transporte até o laboratório, onde foram mantidos em tanques com água do mar e sob aeração constante até o momento da realização dos ensaios. Antes de iniciar o estudo, todos os indivíduos coletados foram limpos de organismos epibentônicos incrustantes. 


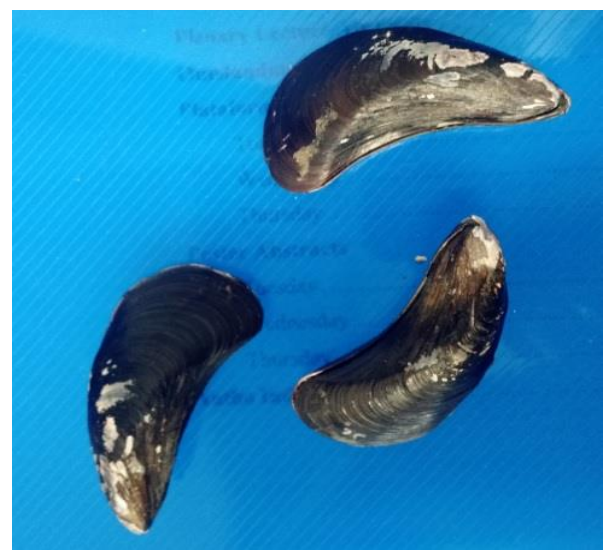

FIGURA 7 - Mexilhões Mytella charruana.

\subsection{Caracterização dos FPCP empregados no estudo}

\subsubsection{Triclosan}

O triclosan (5-CHLORO-2- (2,4-DICHLOROPHENOXY) PHENOL) (Figura 8), é um composto orgânico, de baixa volatilidade, lipofílico e possui massa molecular de 289,5 g.mol ${ }^{-1}$, com constante de dissociação pKa = 7,9 e coeficiente de partição octanol/água $\log \mathrm{K}_{\mathrm{ow}}=4,76$. Devido sua baixa solubilidade, o TCS possui forte ligação com sedimentos, apresentando tempo de meia-vida de mais de 40 dias (USEPA, 2008b; Walters et at., 2010; Huang et al., 2015). O composto utilizado no presente estudo é de procedência da Sigma-Aldrich com pureza $\geq 97 \%$.

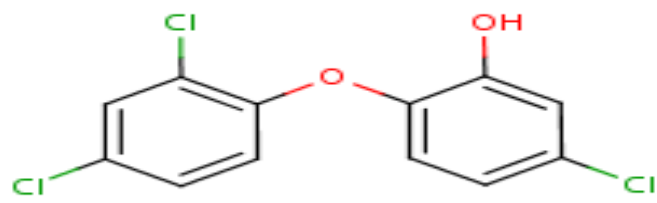

FIGURA 8 - Triclosan $\left(\mathrm{C}_{12} \mathrm{H}_{7} \mathrm{Cl}_{3} \mathrm{O}_{2}\right)$

\subsubsection{Ibuprofeno}

O ibuprofeno (ácido 2-(4-isobutilfenil)propanóico) (Figura 9), é um anti-inflamatório não-esteróide (AINE), possuindo também propriedade analgésica e antipirética. É uma 
substância com característica cristalina e incolor, solúvel em água a partir de $21 \mathrm{mg} \cdot \mathrm{L}^{-1}$, e possui peso molecular de $206.28 \mathrm{~g} \cdot \mathrm{mol}^{-1}$, constante de dissociação $\mathrm{pKa}=4,91 \mathrm{e}$ coeficiente de partição octanol/água log $\mathrm{K}_{\mathrm{ow}}=3,97$. O IBU apresenta tempo de meia-vida de aproximadamente 19 dias em condições aeróbicas, e tempo de meia-vida mais longa em condições anaeróbicas (Conkle et al., 2012). O composto é de procedência da SigmaAldrich com pureza $\geq 98 \%$.<smiles>CC(C)Cc1ccc([C@@H](C)C(=O)O)cc1</smiles>

FIGURA 9 - Ibuprofeno $\left(\mathrm{C}_{13} \mathrm{H}_{18} \mathrm{O}_{2}\right)$

\subsubsection{7 $\alpha$-Etinilestradiol}

O 17a-etinilestradiol (17a-Ethynyl-1,3,5(10)-estratriene-3,17ß-diol) (Figura 10) é um estrogênio sintético, peso molecular 296,40 g. mol${ }^{-1}$, constante de dissociação $\mathrm{pKa}=$ 10,33, e coeficiente de partição octanol/água log $\mathrm{K}_{\mathrm{ow}}=4,2$. De acordo com Zuo et al. (2013), o EE2 é persistente a degradação microbiológica, com tempo de meia-vida estimado em 108 dias em águas superficiais sob condições aeróbicas. O composto utilizado no presente estudo é de procedência da Sigma-Aldrich com pureza $\geq 98 \%$.

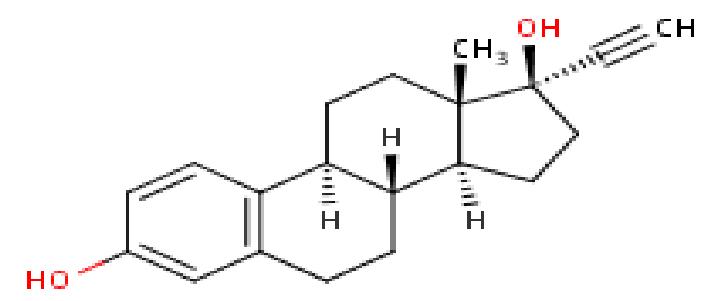

FIGURA 10 - 17a-Etinilestradiol $\left(\mathrm{C}_{20} \mathrm{H}_{24} \mathrm{O}_{2}\right)$ 


\subsection{Avaliação ecotoxicológica dos sedimentos}

\subsubsection{Coleta de sedimentos}

As amostras de sedimento utilizadas nos ensaios ecotoxicológicos foram coletadas em área de referência, distante de grandes centros e de áreas com atividades antrópicas, localizado na praia de Toque Toque Grande, no litoral de São Sebastião, SP. Em 2013, o monitoramento realizado pela CETESB, no que se refere a balneabilidade de praias no litoral de São Paulo, indicou a praia de Toque Toque Grande como "Qualificação Anual Ótima" (CETESB, 2014), o que evidencia pouca influência de esgotos domésticos na região, que é a principal via de entrada dos fármacos.

Para determinação das concentrações ambientais dos fármacos em estudo, foi realizada uma amostragem composta de sedimentos a partir de 5 pontos no entorno do lançamento do esgoto do Emissário Submarino de Santos (ESS), SP (Figura 11). As amostras foram coletadas em fevereiro de 2015 (verão) com auxílio de uma draga do tipo van Veen, acondicionadas em sacos plásticos, e mantidas em caixas térmicas com gelo durante o transporte até o laboratório. Em laboratório, as amostras foram mantidas a temperatura de $4^{\circ} \mathrm{C}$ até a realização das análises. As localizações dos pontos de coleta encontram-se na Figura 11 e as coordenadas geográficas estão descritas na Tabela 1. 


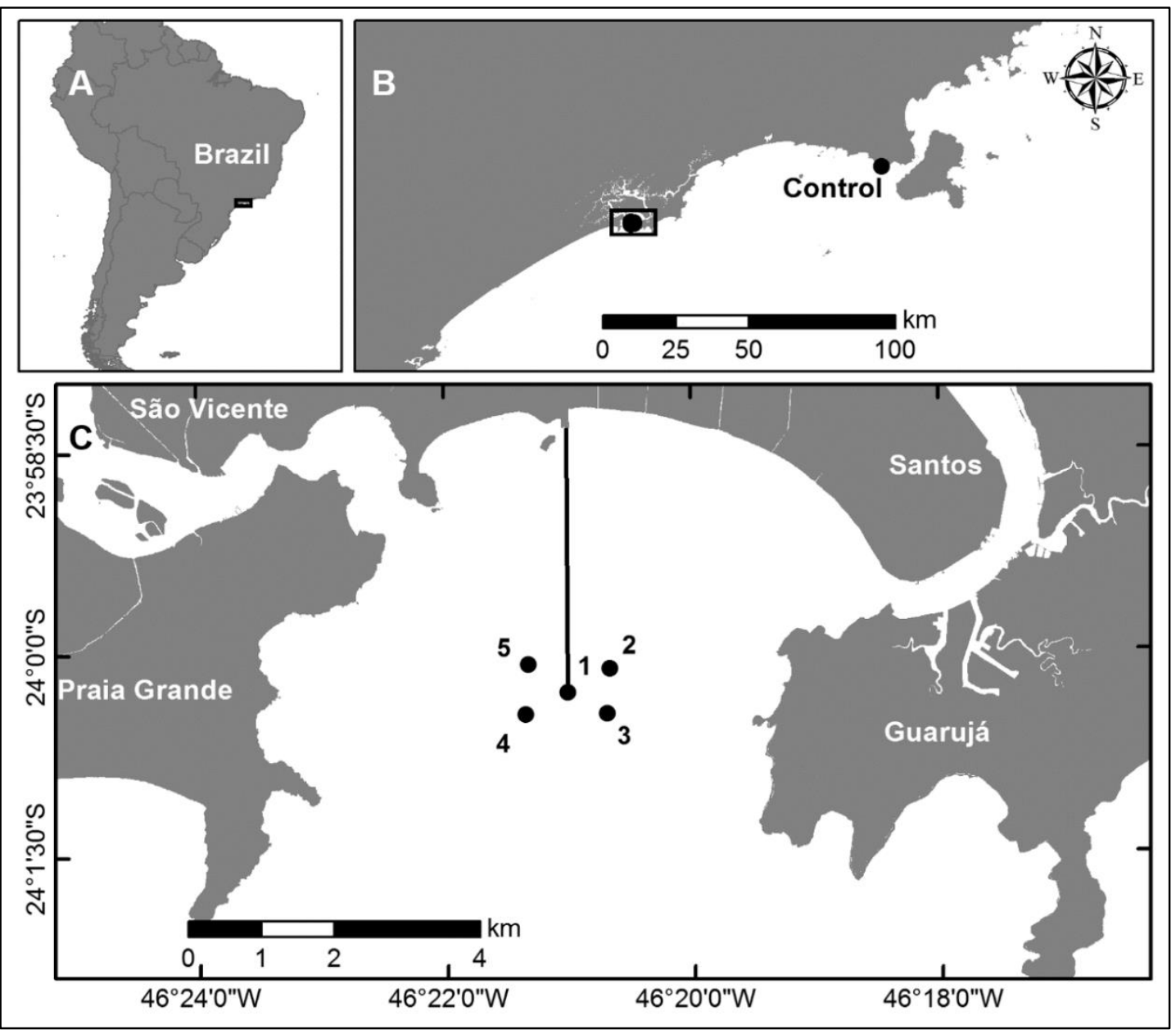

FIGURA 11 - Localização dos pontos de coleta de sedimentos: A) Posição na América do Sul; B) Ponto controle localizado na praia de Toque Toque Grande/São Sebastião; C) Emissário Submarino de Santos (ESS).

TABELA 1 - Coordenadas geográficas dos pontos de coleta.

\begin{tabular}{|c|c|c|}
\hline Locais de amostragem & Latitude & Longitude \\
\hline Ponto 1 & 240ㅇ041"S & 4621'048'W \\
\hline Ponto 2 & 2359'997"S & 4621'664”W \\
\hline Ponto 3 & $23^{\circ} 59^{\prime} 858^{\prime \prime S}$ & 4620'776”W \\
\hline Ponto 4 & $24^{\circ} 00^{\prime} 284^{\prime \prime} S$ & 4621'155”W \\
\hline Ponto 5 & 235'ㄷㄴ"S & 4619'227”W \\
\hline
\end{tabular}




\subsubsection{Caracterização sedimentológica}

O sedimento-marcado (spiked-sediment) empregado nos ensaios foi caracterizado quanto à umidade, granulometria, matéria orgânica e carbonatos. Estes parâmetros foram avaliados antes dos experimentos, seguindo os protocolos padronizados referenciados abaixo.

A determinação da umidade do sedimento controle e análise de distribuição granulométrica de massa, segundo intervalos definidos na escala de Wentworth (Wentworth, 1922), foram realizadas seguindo os procedimentos descritos na Norma Técnica da CETESB L6.160 (1995). Para medir o teor de matéria orgânica foi utilizado o protocolo descrito por Luczak et al., (1997), enquanto a avaliação do teor de carbonatos seguiu os procedimentos descritos por Hirota e Szyper (1975).

\subsubsection{Marcação do sedimento (Spiked-sediment)}

Este método envolve a adição de uma ou mais substâncias químicas em amostras de sedimento formulado para avaliação dos efeitos do composto testado sobre os organismos expostos. O protocolo empregado para o preparo, equilíbrio e mistura do sedimento com o composto foram embasados no manual técnico da USEPA (2001).

A marcação do sedimento foi realizada com auxílio de um equipamento denominado jar-rolling, que foi desenvolvido neste estudo e consiste em uma máquina que gira em dois eixos diferentes de forma simultânea (FIGURA 12). Esta técnica é considerada a mais eficaz para homogeneização dos compostos em grandes volumes do sedimento (USEPA, 2001). 


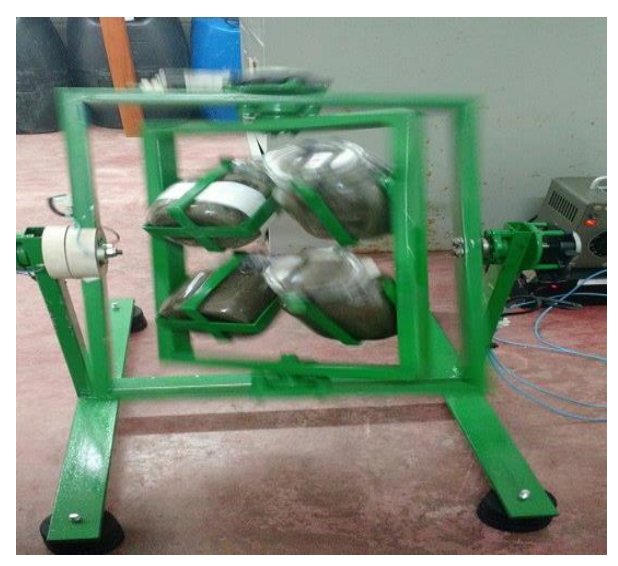

FIGURA 12 - Homogeneizador mecânico de sedimentos do tipo Jar-rolling de duas rotações desenvolvido para realização deste estudo.

A técnica utilizada consistiu na adição de $500 \mathrm{~g}$ de sedimento úmido nos frascos do jar-rolling $(1 \mathrm{~L})$, e em seguida foi adicionado ao sedimento $50 \mathrm{~mL}$ de solução dos compostos testados na concentração desejada. Em seguida, os frascos com a mistura de sedimento e solução dos compostos foram agitados por 30 minutos. Após o procedimento de mistura, os frascos foram mantidos por 7 dias em ambiente com temperatura controlada $\left(4 \pm 2^{\circ} \mathrm{C}\right)$ e sem iluminação para que se estabelecesse o equilíbrio químico entre as substâncias-teste, o sedimento e a água intersticial (Francis et al., 1984).

Após os procedimentos de mistura e equilíbrio, os sedimentos marcados foram utilizados em 3 tipos de exposição: sedimento integral, interface sedimento-água e elutriato.

A exposição ao sedimento integral (SI) visa a exposição direta dos organismos ao sedimento contaminado com FPCP. O sistema de interface sedimento-água (ISA) avalia a toxicidade do sedimento contaminado a partir da solubilização do composto testado, além de fluxos ascendentes de água intersticial contaminada à água de coluna imediatamente superior ao sedimento. Este sistema foi proposto por Anderson et al. (1996) e adaptado por Cesar et al. (2004), e consiste em tubos de ensaio contendo $2 \mathrm{~mL}$ de sedimento marcado e $8 \mathrm{~mL}$ de água de diluição, com uma rede de plâncton logo acima do sedimento para facilitar a recuperação das larvas no final do experimento (Figura 13). 
O sistema-teste foi montado com no mínimo $12 \mathrm{~h}$ de antecedência ao início dos experimentos para possibilitar o equilíbrio entre o sedimento e a água sobrejacente.

Sistema interface sedimento-água

(4 água: 1 sedimento)

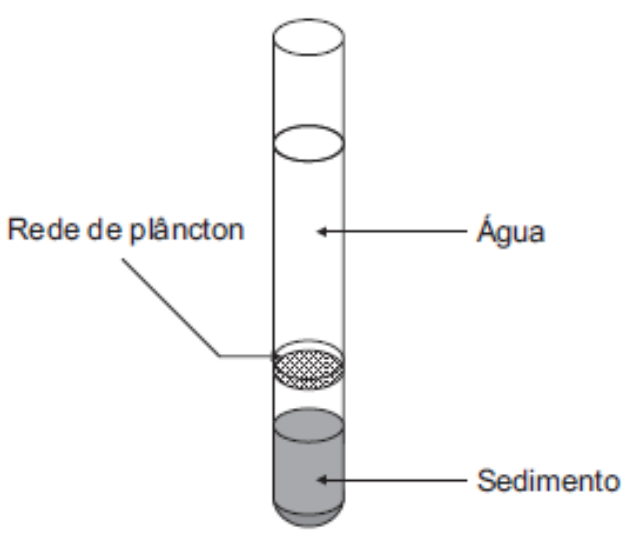

FIGURA 13 - Sistema de preparação dos testes com interface sedimento-água.

O elutriato do sedimento (ELU), que simula um processo de ressuspensão do sedimento e possível solubilização do composto testado, foi obtido por meio da mistura do sedimento marcado com água de diluição na proporção de 1:4 (sedimento-água). Essa mistura foi submetida a agitação com auxílio de um agitador mecânico durante 30 min (Figura 14). Após a sedimentação, o sobrenadante foi utilizado para o ensaio.

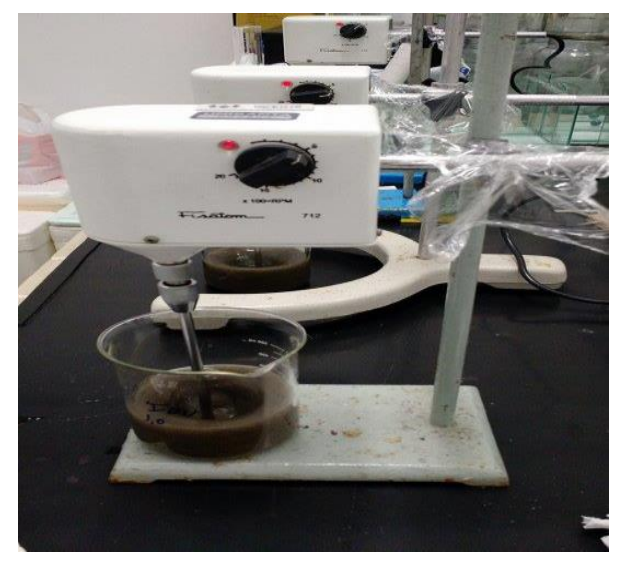

FIGURA 14 - Preparo do elutriato com agitador mecânico. 
A água de diluição utilizada nos experimentos foi preparada por meio da diluição de sal marinho (Redsea ${ }^{\circledR}$ ) em água destilada, com salinidade entre 30 e 36 ppm (de acordo com a espécie testada), e filtrada em membrana de celulose com porosidade de $0,22 \mu \mathrm{m}$.

A taxa de degradação de FPCP nos sedimentos varia de acordo com o tempo de meia-vida de cada composto. No presente estudo, não foram levados em consideração produtos de degradação, uma vez que o tempo de meia-vida do TCS (USEPA, 2008b; Huang et al., 2015), IBU (Conkle et al., 2012) e EE2 (Zuo et al., 2013) são todos acima de 14 dias.

\subsubsection{Método analítico}

Os procedimentos para as análises químicas dos sedimentos foram conduzidos no Laboratório do CEMSA (Centro de Espectrometria de Massas Aplicada) sob coordenação do Prof. MSc. Daniel Temponi Lebre. As análises químicas dos sedimentos foram realizadas com base no protocolo da USEPA (2007). As amostras de sedimento marcado $\mathrm{e}$ as provenientes do ESS ( $1 \mathrm{~g}$ peso/seco) foram homogeneizadas $\mathrm{e}$ processadas pelo método de extração ácida, por meio da adição de $10 \mathrm{~mL}$ de acetonitrila às amostras. Após este procedimento, as amostras foram levadas a um ultrassom por 30 minutos. Posteriormente, as amostras foram centrifugadas por $5 \mathrm{~min}$. (2500 rpm) e o sobrenadante separado. Os sólidos resultantes da centrifugação foram ressuspensos em $10 \mathrm{~mL}$ de tampão fosfato $(\mathrm{pH} 2,0)$. Novamente as amostras foram levadas a um ultrassom por 30 minutos e centrifugadas por $5 \mathrm{~min}(2500 \mathrm{rpm})$ e o sobrenadante separado. $\mathrm{O}$ processo extrativo foi repetido pela terceira vez, foi adicionado $10 \mathrm{~mL}$ de acetonitrila às amostras, as quais foram centrifugadas e o sobrenadante separado.

O sobrenadante acumulado foi misturado e centrifugado por 5 minutos a $2500 \mathrm{rpm}$. Após este procedimento, $25 \mathrm{~mL}$ do sobrenadante centrifugado foi adicionado a $250 \mathrm{~mL}$ de água Milli- ${ }^{\circledR}$ e em seguida foi realizada a etapa de clean-up (Extração em fase sólida - EFS). 
A EFS foi realizada utilizando cartucho Xtrata - X $33 \mu$ Polymeric Reversed Phase (200 mg / $3 \mathrm{~mL}$, Phenomenex). As colunas foram pré-condicionadas com $2 \mathrm{~mL}$ de acetonitrila; $2 \mathrm{~mL}$ de metanol:isopropanol:acetonitrila (1:1:1); $2 \mathrm{~mL}$ de água Milli- ${ }^{\circledR}$. Para etapa de percolação das amostras nos cartuchos foram utilizados $25 \mathrm{~mL}$ do extrato e 250 $\mathrm{mL}$ de água Milli- $\mathrm{Q}^{\circledR}$. Após este procedimento, os cartuchos foram mantidos por 5 minutos sob secagem a vácuo.

A eluição foi realizada utilizando $3 \mathrm{~mL}$ de metanol e $3 \mathrm{~mL}$ de acetona:metanol (1:1). Posteriormente o eluato foi levado a secura total sob fluxo suave de ar comprimido a fim de eliminar o solvente orgânico proveniente da etapa de EFS. Em seguida foi retomado com $500 \mu \mathrm{L}$ de Metanol: $\mathrm{H}_{2} \mathrm{O}$ (7:3) e injetado no sistema HPLC-MS/MS em modo de operação MRM (Multiple Reaction Monitoring), com fonte de íons ESI no modo negativo.

As condições utilizadas para separação estão descritas na Tabela 2. A linearidade e exatidão do método foram avaliadas utilizando amostras de sedimento não contaminados (brancos), aos quais foram adicionadas diferentes concentrações dos compostos analisados.

TABELA 2 - Condições cromatográficas.

\begin{tabular}{lc}
\hline & Condições Cromatográficas \\
\hline Coluna & Agilent Eclipse XDB-C18 3.0x75 mm, 3.5 $\mu \mathrm{m}$ \\
Fase móvel A & $5 \mathrm{mM}$ Acetato de Amônio \\
Fase móvel B & Metanol \\
Temp. da coluna & $25^{\circ} \mathrm{C}$ \\
Vazão & $0,4 \mathrm{~mL} \cdot \mathrm{min}^{-1}$ \\
Vol. de injeção & $10 \mu \mathrm{L}$ \\
Tempo de corrida & $2,5 \mathrm{~min}$ \\
Sol. lavagem de agulha & Acetonitrila:água $(60: 40)(\mathrm{v} / \mathrm{v})$ \\
\hline
\end{tabular}

\subsubsection{Avaliação da toxicidade}

Os efeitos crônicos dos compostos estudados foram avaliados, em nível de indivíduo, através da observação do desenvolvimento embriolarval de duas espécies 
marinhas (mexilhão Perna perna e ouriço-do-mar Lytechinus variegatus) e, em nível subindividual, por meio da avaliação do estresse celular (estabilidade da membrana lisossômica por meio do ensaio de vermelho neutro) e efeitos bioquímicos em mexilhões estuarinos (Mytella charruana).

\subsubsection{Ensaios de toxicidade com mexilhão Perna perna}

Os ensaios de toxicidade para avaliação de efeitos crônicos no desenvolvimento de embriões do mexilhão Perna perna foram realizados de acordo com o método descrito por Zaroni et al. (2005). Os experimentos foram realizados no Laboratório de Ecotoxicologia da Universidade Santa Cecília - Unisanta.

O princípio deste método foi de expor embriões de $P$. perna a diferentes concentrações dos compostos analisados, por meio de exposição a ISA e ELU, e analisar, após 48 horas de exposição, o desenvolvimento embriolarval.

A técnica utilizada para induzir a liberação dos gametas foi por estímulo físico, por meio da indução termal. Os gametas foram coletados com auxílio de uma pipeta de Pasteur. O líquido espermático coletado foi mantido no gelo até o momento da fecundação. Os ovócitos foram lavados com auxílio de peneira de $0,75 \mu \mathrm{m}$ e colocados em um béquer com cerca de 1,5 L de água do mar filtrada em membrana Millipore 0,22 $\mu \mathrm{m}$.

A fecundação foi obtida pela adição de $2 \mathrm{~mL}$ da solução espermática à solução de ovócitos, e a densidade de ovos foi estimada pela diluição da concentração de ovos em água do mar e contagens em câmara de Sedgwick-Rafter. Cerca de 500 ovos recémfertilizados foram inseridos nos frascos-teste, e os ensaios foram mantidos na temperatura de $25 \pm 1^{\circ} \mathrm{C}$, por 48 horas, tempo suficiente para o desenvolvimento dos embriões até larva-D.

Após o período de desenvolvimento dos embriões, as amostras foram fixadas com 0,5 $\mathrm{mL}$ de formol $40 \%$ (tamponado com Bórax em $\mathrm{pH} 7,0$ ) para posterior avaliação das 100 primeiras larvas encontradas em cada amostra. A porcentagem de larvas normais das amostras foi comparada com a porcentagem de larvas normais do grupo controle. 
Assim, um aumento da incidência de anomalias ou retardo no desenvolvimento das larvas foi observado e analisado, gerando informações sobre a capacidade de desenvolvimento das larvas de mexilhões expostas às diferentes concentrações dos compostos.

Em paralelo aos ensaios com sedimento, foram realizados ensaios de sensibilidade com a substância de referência Dodecil Sulfato de Sódio (DSS). A Tabela 3 apresenta um resumo da metodologia do ensaio.

TABELA 3 - Condições para realização e critérios de aceitabilidade dos ensaios de toxicidade crônica com mexilhão $P$. perna.

\begin{tabular}{ll}
\hline Parâmetros & Condições \\
\hline Sistema de ensaio & Estático \\
Concentrações & Controle e 4 concentrações \\
Substâncias & Triclosan/lbuprofeno/EE2 \\
Temperatura & $25 \pm 1 \stackrel{\text { oC }}{ }$ \\
Salinidade & 32 a 35 ppt. \\
Fotoperíodo & $16 \mathrm{~h}$ luz / 8h escuro \\
Água de diluição & Água marinha reconstituída \\
Câmera teste & Tubo de ensaio com capacidade para \\
Volume de água & $15 \mathrm{~mL}$ \\
Substrato & $8 \mathrm{~mL}$ \\
Idade do organismo-teste & $2 \mathrm{~g}$ de sedimento \\
№ de organismos por réplica & Ovos recém fecundados \\
№ de réplicas por tratamento & 50 organismos por mL \\
Alimentação & 4 \\
Duração do teste & Ausente \\
Efeito observado & 48 horas \\
Validade do ensaio & Retardo ou anormalidade no \\
\hline
\end{tabular}




\subsubsection{Ensaios de toxicidade com ouriço-do-mar Lytechinus variegatus}

Os ensaios de toxicidade para avaliação de efeitos crônicos no desenvolvimento embriolarval do ouriço-do-mar Lytechinus variegatus foram realizados de acordo com os procedimentos descritos pela USEPA (1995), com adaptações para a espécie pela NBR 15350, referentes ao tempo de exposição e temperatura (ABNT, 2012). Os experimentos foram realizados no Laboratório de Ecotoxicologia da Universidade Santa Cecília Unisanta, o qual possui acreditação pelo INMETRO na norma ISO/IEC 17025 para ensaios de avaliação de efeito crônico com Lytechinus variegatus.

O ensaio consistiu na exposição de embriões de ouriço-do-mar por um período de 24 a 28 horas às amostras recém-processadas (ISA e ELU) e, após o período de exposição, avaliou-se o número de larvas apresentando desenvolvimento normal e anômalo.

A água de diluição utilizada nos experimentos, tanto para a obtenção dos gametas como para o preparo dos controles e das amostras de sedimento marcado, foi preparada por meio da diluição de sal marinho (Redseaß) em água destilada, na concentração de 30 a $36 \%$, e filtrada em membrana de celulose com porosidade de 0,22 $\mu \mathrm{m}$.

A indução da liberação dos gametas foi realizada por meio da injeção de $\mathrm{KCl} 0,5$ mol. Para coleta dos óvulos, identificados por sua coloração amarelo-alaranjados, as fêmeas foram apoiadas com a superfície aboral voltada para baixo em um recipiente menor que o seu diâmetro, com água de diluição à temperatura do ensaio (Figura 15). Após a sedimentação dos óvulos, foi descartado o sobrenadante e as soluções foram filtradas em malha de $350 \mu \mathrm{m}$ para reter espinhos e fezes que podem ser liberados juntamente com os gametas. Após este procedimento foi acrescentada à solução de óvulos, água de diluição elevando o volume para $600 \mathrm{~mL}$. 


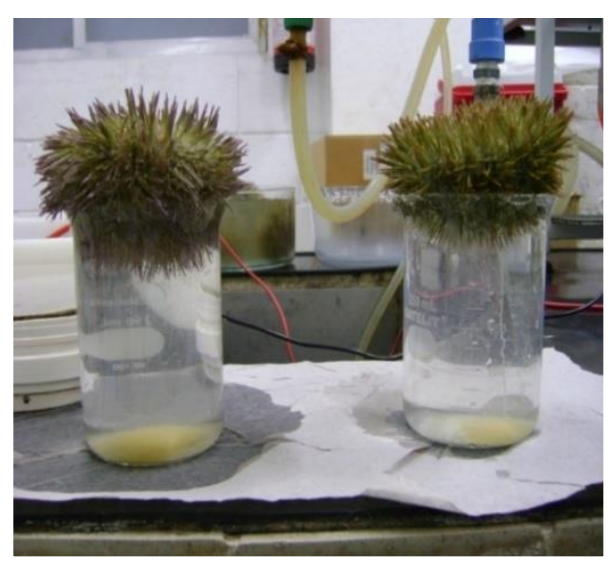

FIGURA 15 - Liberação de gametas fêmea, ovócitos no fundo do Becker.

Os espermatozoides, identificados pela sua cor branca, foram coletados com auxílio de uma pipeta de Pasteur de ponta fina diretamente dos gonóporos, e acondicionados em um béquer seco envolto com gelo, sem que os espermatozoides entrassem em contato com água de diluição até o início dos experimentos (Figura 16).

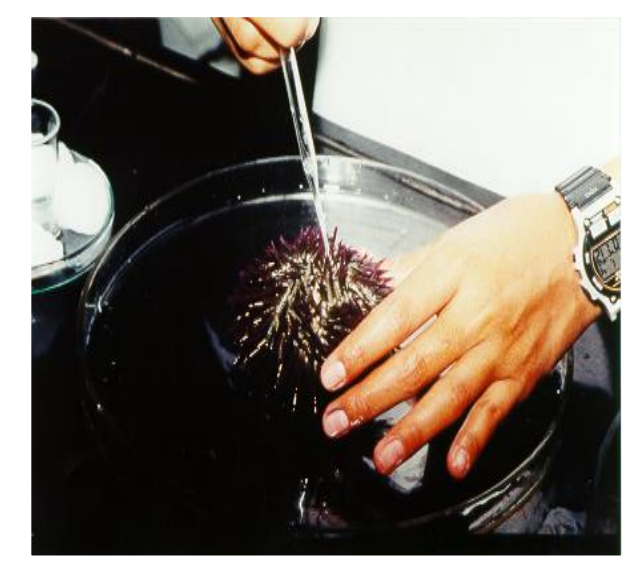

FIGURA 16 - Coleta de espermatozoides

No momento da fecundação foi preparada uma solução na proporção de $0,5 \mathrm{~mL}$ de espermatozoides para $25 \mathrm{~mL}$ de água de diluição. Esta solução foi misturada de modo a proporcionar a dissolução de possíveis grumos. Em seguida, foi acrescentado um volume de 1,2 a $2 \mathrm{~mL}$ da solução de esperma ao recipiente contendo os óvulos e aguardado 10 minutos com leve agitação. 
Após este período, três sub-amostras de $10 \mu \mathrm{L}$ da solução foram colocadas em câmara de Sedgwick-Rafter para contagem e cálculo da porcentagem de fecundação. $O$ critério de aceitabilidade para o ensaio é de no mínimo $80 \%$ de ovócitos fertilizados. 0 procedimento de contagem dos ovos nas três sub-amostras possibilita estimar a média do número de ovos $/ \mathrm{mL}$ e o cálculo do volume da solução a ser adicionada nas concentrações-teste contendo 300 ovos. Vale ressaltar que o volume adicionado nos recipientes-teste não pode ultrapassar $100 \mu \mathrm{L}$, critério a ser respeitado.

Para cada tratamento foram utilizadas 4 réplicas, onde foram inseridos cerca de 300 ovos, e o conjunto mantido de 24 a 28 horas em câmara incubadora com temperatura constante de $25 \pm 2^{\circ} \mathrm{C}$ e fotoperíodo $16 \mathrm{~h} / 8 \mathrm{~h}$ (luz-escuro). Após o período de exposição, o ensaio foi encerrado adicionando em todas as réplicas $0,5 \mathrm{~mL}$ de formol tamponado com bórax.

Posteriormente, o conteúdo de cada réplica foi observado em microscópio em lâmina de Sedgewick-Rafter. Os primeiros 100 embriões foram contados e seu grau de desenvolvimento analisado. Embriões que atingiram seu estágio de larva Pluteus bem desenvolvido foram considerados normais, enquanto aqueles apresentando alteração morfológica e/ou retardo no desenvolvimento foram considerados anômalos.

Em paralelo aos ensaios com sedimento, foram realizados ensaios de sensibilidade com a substância de referência Sulfato de Zinco. A Tabela 4 apresenta um resumo da metodologia do ensaio. 
TABELA 4 - Condições para realização e critérios de aceitabilidade dos ensaios de toxicidade crônica com ouriço-do-mar Lytechinus variegatus.

\begin{tabular}{ll}
\hline Parâmetros & Condições \\
\hline Sistema de ensaio & Estático \\
Concentrações & Controle e 4 concentrações \\
Substâncias & Triclosan/lbuprofeno/EE2 \\
Temperatura & $25 \pm 1^{\circ} \mathrm{C}$ \\
Salinidade & $30 \mathrm{a} 36 \mathrm{ppt}$ \\
Fotoperíodo & $16 \mathrm{~h}$ luz / 8h escuro \\
Água de diluição & Água marinha reconstituída \\
Câmera teste & Tubo de ensaio com capacidade para \\
Volume de água & $15 \mathrm{~mL}$ \\
Substrato & $8 \mathrm{~mL}$ \\
Idade do organismo-teste & $2 \mathrm{~g}$ de sedimento \\
№ de organismos por réplica & Ovos recém fecundados \\
№ de réplicas por tratamento & 30 organismos por mL \\
Alimentação & 4 \\
Duração do teste & Ausente \\
Efeito observado & 24 a 28 horas \\
Validade do ensaio & Retardo ou anormalidade no \\
& desenvolvimento embriolarval \\
\hline
\end{tabular}

\subsubsection{Ensaio de citotoxicidade com mexilhão Mytella charruana}

O método utilizado para avaliação da citotoxicidade foi o de análise do tempo de retenção do corante Vermelho Neutro (TRCVN) em lisossomos de hemócitos, que seguiu os procedimentos descritos por Lowe et al. (1995). Os experimentos foram realizados no Laboratório de Ecotoxicologia da Universidade Santa Cecília - Unisanta. 
O ensaio para avaliação do TRCVN baseia-se no princípio de que os lisossomos de células saudáveis conseguem reter o corante vermelho neutro por um certo período de tempo, enquanto que danos na integridade e estabilidade da membrana lisossomal causados pelo acumulo de xenobióticos diminuem o tempo de retenção do corante, induzindo o vazamento de componentes do lisossoma para o citosol mais rapidamente (Dailianis et al., 2003).

Para realização de cada experimento, organismos adultos da espécie Mytella charruana $(n=12)$ foram expostos ao sedimento integral com diferentes concentrações de TCS, IBU e EE2, por um período de 24 horas, sem alimentação, com fotoperíodo de 16 h luz, com temperatura controlada de $20^{\circ} \mathrm{C} \pm 2^{\circ} \mathrm{C}$ e salinidade de $30 \%$. Foram utilizadas 4 réplicas por concentração, incluindo o controle, com $300 \mathrm{~g}$ de sedimento marcado, na proporção de 1:4 (sedimento-água).

\subsection{Preparação das lâminas}

As lâminas foram preparadas imediatamente antes do experimento. Lâminas com tamanho $76 \times 26 \mathrm{~mm}$ foram pré-tratadas com solução de Poly-L-lisina para facilitar a adesão dos hemócitos na lâmina. A solução foi preparada pela diluição de Poly-L-lisina em água destilada na proporção de 1:10. Com o auxílio de uma micropipeta, foi transferido $10 \mu \mathrm{L}$ dessa solução de trabalho sobre cada lâmina, deslizando e espalhando o líquido sobre toda a superfície com auxílio de uma lamínula.

\subsection{Preparação das soluções}

\section{- Solução fisiológica}

A solução fisiológica foi preparada um dia antes do experimento. Esta solução salina foi utilizada para diluir a hemolinfa dos mexilhões.

Foram pesados 4,77 g de HEPES; $25,48 \mathrm{~g}$ de cloreto de sódio; $13,06 \mathrm{~g}$ de sulfato de magnésio; $0,75 \mathrm{~g}$ de cloreto de potássio; $1,47 \mathrm{~g}$ de cloreto de cálcio, e adicionado em $1 \mathrm{~L}$ de água destilada, em um balão de vidro volumétrico. 
$\mathrm{O}$ pH da solução salina foi ajustado para 7,36 usando um pH-metro e, quando necessário, ajustado utilizando $\mathrm{NaOH}$ ou $\mathrm{HCl}$. Isto foi feito imediatamente antes de cada uso da solução fisiológica.

\section{- Vermelho Neutro (NR)}

A solução de vermelho neutro pode ser preparada até 2 semanas antes do uso. Porém, para maior consistência, uma solução nova foi preparada imediatamente antes do uso, isto é, nos últimos 5 a 10 minutos de tempo em que as células estavam se aderindo nas lâminas.

\section{- Solução-estoque}

O NR foi preparado como uma solução-estoque no solvente DMSO. A solução de trabalho foi preparada a partir da solução-estoque, por diluição em solução fisiológica.

Foi pesado $28,8 \mathrm{mg}$ de NR (mantido em refrigerador) e colocado em um frasco de vidro âmbar, adicionando $1 \mathrm{~mL}$ de DMSO com auxílio de uma pipeta. O NR foi dissolvido no DMSO com uma suave agitação. Esta solução-estoque foi estocada em refrigerador dentro de um recipiente à prova de luz, pois o NR é fotossensível. O estoque é estável por um período de cerca de 2 a 3 semanas.

\section{- Solução de trabalho}

Para preparar a solução de trabalho, o estoque foi retirado da geladeira e deixado em temperatura ambiente, na qual ele derrete. Foi tomado o cuidado de manter as soluções ao abrigo da luz. Para se assegurar que nenhum cristal de NR estivesse presente no estoque antes da diluição em solução de trabalho, foi utilizado um agitador por 1-2 minutos para homogeneizar totalmente o estoque. Utilizando uma micropipeta, foi introduzido $5 \mathrm{~mL}$ de solução fisiológica em um frasco escuro. Então, com cuidado de inserir a ponteira de micropipeta logo abaixo do menisco da solução estoque dentro do frasco, foi pipetado $10 \mu \mathrm{L}$ de solução-estoque. Isto previne que algum cristal não 
dissolvido presente na solução-estoque contamine a solução de trabalho. Este volume foi adicionado na solução fisiológica previamente pipetada.

A solução de trabalho foi mantida em uma câmara úmida e à prova de luz, para prevenir a foto-oxidação. A solução é instável e por isso foi preparada a cada nova bateria de lâminas analisadas.

\subsection{Extração da hemolinfa}

Após a exposição dos organismos aos fármacos, foram retiradas amostras da hemolinfa de todos os mexilhões expostos.

Para extração da hemolinfa, as valvas do mexilhão foram separadas cuidadosamente por alguns milímetros, inserindo a lâmina de um bisturi ao longo da superfície ventral (o lado de onde partem os fios do bisso, que possui uma depressão natural que facilita este ato). $O$ bisturi foi mantido na posição em que as valvas ficam abertas.

A água de dentro das conchas foi drenada para assegurar que todo o líquido extraído fosse hemolinfa e não água do mar. Com o auxílio de uma seringa hipodérmica de $2 \mathrm{~mL}$ contendo $0,5 \mathrm{~mL}$ de solução fisiológica, coletou-se $0,5 \mathrm{~mL}$ de hemolinfa do músculo adutor posterior.

A localização do músculo adutor posterior é obtida inserindo suavemente a agulha entre a ponta das valvas, nos primeiros centímetros, e cuidadosamente movendo-a horizontalmente até encontrar certa resistência, dada pelo toque com o músculo. $A$ agulha foi inserida na superfície do músculo para extração da hemolinfa. Uma extração eficiente pode ser observada quando a seringa é colocada contra a luz e um líquido levemente leitoso (comparado com a solução salina transparente) pode ser observado dentro dela.

\subsection{Manuseio da hemolinfa}

Após obter uma amostra de hemolinfa, a agulha da seringa foi removida e o conteúdo da seringa transferido para os tubos de microcentrífuga com volume de $2 \mathrm{~mL}$, 
onde foram mantidos por no máximo 15 a 20 minutos. Este procedimento serve para minimizar as forças de adesão que podem romper as células e facilitar a coagulação. Foi necessário usar tubos siliconados para prevenir os hemócitos de aderirem nas paredes do tubo.

O conteúdo dos tubos foi suavemente misturado antes de aplicá-lo sobre a superfície das lâminas. Isto foi feito invertendo-se os tubos de modo suave, para minimizar a possibilidade de coagulação; e como os hemócitos rapidamente precipitam, a aplicação da solução de células foi imediatamente coletada após esta inversão.

Foi pipetado cerca de $40 \mu \mathrm{L}$ desta solução de células (hemolinfa + solução fisiológica) sobre a superfície de uma lâmina previamente tratada com Poly-L-lisina, usando uma ponteira de pipeta limpa para cada amostra.

As lâminas foram colocadas em uma câmara úmida à prova de luz e incubadas por 15 minutos, permitindo que as células ficassem aderidas nas lâminas. Após a incubação, foi retirado o excesso em suspensão e limpa a área ao redor de onde estão as células para remover o excesso de fluido.

Isto foi necessário para que os hemócitos aderidos na lâmina estivessem totalmente expostos ao vermelho neutro no próximo estágio, e também eliminou o efeito de flutuar que eventualmente ocorre com a lamínula quando há excesso de líquido. Uma monocamada de hemócitos pôde ser observada como pequenos pontos na lâmina quando esta é colocada contra a luz.

\subsection{Incubação}

Foi pipetado $40 \mu \mathrm{L}$ de solução de trabalho de vermelho neutro sobre a camada de hemócitos de cada lâmina, dentro da câmara úmida e à prova de luz. Isto foi feito de modo suave, tocando a superfície da lâmina com a ponta da pipeta e lentamente derramando o corante sobre as células. 
Após 15 minutos de incubação na câmara o corante penetra nas células. Ao final deste período, a lâmina foi coberta com uma lamínula, com cuidado de evitar bolhas de ar.

As lâminas foram sistematicamente examinadas em microscópio a cada 15 minutos na primeira hora e a cada 30 minutos na segunda hora, até 120 min. A observação final foi feita após 180 minutos de exposição.

As células foram examinadas com lentes com 400X ou 500X de aumento. Cada lâmina foi examinada e reposta em 1 minuto. Como o NR é muito sensível à luz, é recomendável que todas as lâminas recebam a mesma exposição à luz durante os exames.

A luz do microscópio foi mantida a mais baixa possível para permitir uma boa visualização das células. As células foram examinadas tanto para anormalidades estruturais como para o tempo de retenção do vermelho neutro. A cada contagem as condições foram anotadas em uma tabela. O tempo de retenção do NR pelos lisossomos foi obtido pela estimativa da proporção de células exibindo "vazamento" dos lisossomos para o citosol e/ou exibindo anormalidades no tamanho e cor dos lisossomos. A forma das células pode também modificar-se como consequência do impacto causado por contaminantes. A Tabela 5 apresenta os critérios seguidos para diferenciação de células saudáveis e estressadas.

TABELA 5 - Critérios para diferenciação de células saudáveis e estressadas

\begin{tabular}{lll}
\hline Critério & Células saudáveis & Células estressadas \\
\hline Formato das células & Irregular & Arredondado \\
Tamanho das células & Aumentado & Diminuído \\
Número de lisossomos & Aumentado & Diminuído \\
Tamanho dos lisossomos & Menores & Alargados/Aumentados \\
Cor dos lisossomos & Vermelho pálido/rosado & Vermelho ou rosa escuro \\
Pseudópodes & Não visíveis & Visíveis \\
Corante extravasado no citosol & Não visíveis & Visíveis \\
\hline
\end{tabular}


O "end point" foi tomado quando $50 \%$ ou mais das células exibiram anomalias estruturais ou perda de material (Fig. 17 e 18). O valor usado para o cálculo do tempo de retenção corresponde ao último período anotado em que não houve evidência de estresse.
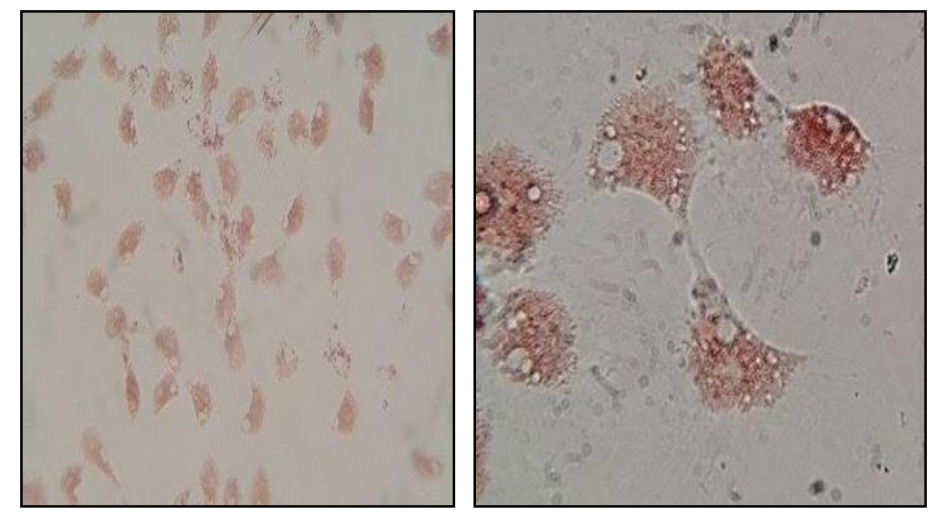

FIGURA 17 - Células saudáveis
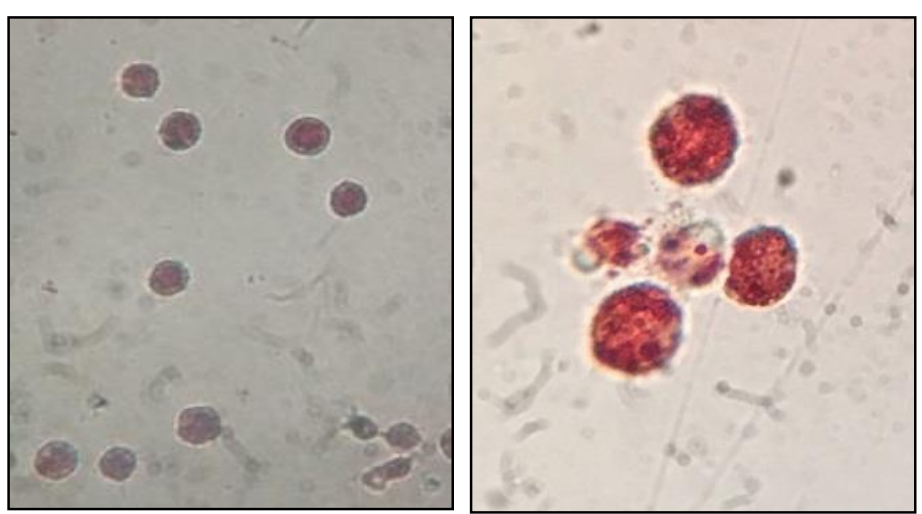

FIGURA 18 - Células estressadas

\subsubsection{Análise de atividades enzimáticas}

A análise de atividades de CYP450 (EROD e DBF) foram conduzidas no Departamento de Biociências da Universidade Federal de São Paulo - Unifesp (Campus Baixada Santista), sob coordenação do Prof. Dr. Marcos Leoni Gazarini Dutra, enquanto que as análises da Glutationa-S-transferase, Glutationa peroxidase, danos em DNA, peroxidação lipídica e colinesterase foram realizadas no Laboratório do Núcleo de Estudos em Poluição e Ecotoxicologia Aquática (NEPEA) da Universidade Estadual Paulista "Júlio de Mesquita Filho" - Unesp (Campus Litoral Paulista), sob coordenação do Prof. Dr. Denis Moledo de Souza Abessa e da Profa. Dra. Luciane Alves Maranho. 
Para as análises das atividades enzimáticas de $M$. charruana, foram utilizadas as brânquias e as glândulas digestivas dos organismos coletadas imediatamente após a exposição aos sedimentos contaminados com compostos farmacêuticos. Os tecidos foram dissecados com auxílio de um bisturi e mantidos congelados $\left(-80^{\circ} \mathrm{C}\right)$ até a realização das análises.

Os tecidos (brânquias e glândulas digestivas) foram homogeneizados para cada pool de organismos $(n=4)$. Este procedimento foi realizado em gelo, utilizando um aparelho triturador de tecidos, os quais foram homogeneizados com solução tampão $(\mathrm{pH}$ 7,5), contendo $100 \mathrm{mM} \mathrm{NaCl}, 25 \mathrm{mM}$ Hepes- $\mathrm{NaOH}, 1 \mathrm{mM}$ EDTA e $1 \mathrm{mM}$ dithiothreitol (DTT) (Gagné et al., 2007). O tecido homogeneizado foi utilizado para análises de peroxidação lipídica e danos em DNA. O restante do tecido homogeneizado foi centrifugado a $12000 \mathrm{~g}$ a $4^{\circ} \mathrm{C}$ durante 20 min para análise dos demais biomarcadores. $\mathrm{O}$ sobrenadante utilizado para as análises foi armazenado a $-80^{\circ} \mathrm{C}$ até a realização de cada biomarcador.

As respostas dos biomarcadores foram normalizadas pelo teor de proteínas totais de cada extrato correspondente aos tecidos das brânquias e glândulas digestivas. $O$ teor total de proteína $\left(\mathrm{mg} \cdot \mathrm{mL}^{-1}\right)$ foi determinado para cada extrato de acordo com o método de Bradford (1976), utilizando soro de bovino para a calibração. Todas as respostas de biomarcadores foram determinadas usando o software Infinite 200 reader and Tecan icontrol 1.7 .

\subsection{Etoxiresorufina-O-deetilase (EROD)}

A atividade da EROD foi avaliada pelo ensaio adaptado de Gagné \& Blaise (1993). Por este método, $50 \mu \mathrm{L}$ de $\mathrm{S} 10$ foi adicionado a $10 \mu \mathrm{M} 7$ - etoxiresorufina e $10 \mathrm{mM}$ NADPH reduzida em tampão 100 mM KH2PO4 (pH 7,4).

A reação foi iniciada pela adição de $\mathrm{NADPH}$, mantida por 60 min a $30^{\circ} \mathrm{C}$, e finalizada pela adição de $100 \mu \mathrm{L}$ de $0,1 \mathrm{M}$ de $\mathrm{NaOH}$. 7-hidroxiresorufina foi determinado fluorometricamente utilizando filtros de $520 \mathrm{~nm}$ (excitação) e $590 \mathrm{~nm}$ (emissão). A determinação de 7-hidroxiresorufina nas amostras foi realizada utilizando-se uma curva 
padrão de calibração de 7- hidroxiresorufina. Os resultados foram expressos em nmol. $\mathrm{min}^{-1} \cdot \mathrm{mg}^{-1}$ proteína total.

\subsection{Dibenzilfluoresceína (DBF)}

No presente estudo, a determinação da atividade da DBF foi realizada de acordo com método descrito por Gagné et al. (2007) utilizando como substrato dibenzilfluoresceína 10 uM e incubada com uma solução de $1 \mathrm{mM}$ de NADPH em uma solução de ensaio (50 mM NaCl contendo 10 mM HEPES-NaOH, pH 7,4). A fluorescência da amostra foi medida com um filtro de $485 \mathrm{~nm}$ de excitação e emissão de $516 \mathrm{~nm}$. Os resultados foram expressos em nmol. $\mathrm{min}^{-1} \cdot \mathrm{mg}^{-1}$ proteína total.

\subsection{Glutationa-S-transferase (GST)}

O procedimento de determinação da atividade da GST foi adaptado de McFarland et al. (1999). A atividade foi analisada utilizando $42 \mathrm{mM}$ 1-cloro-2,4-dinitrobenzeno (CDNB) e $1 \mathrm{mM}$ GSH como substrato e medido espectrofotometricamente a $340 \mathrm{~nm}$ a cada 5 min durante 30 minutos. Resultados foram expressos em nmol. $\mathrm{min}^{-1} . \mathrm{mg}^{-1}$ proteína total.

\subsection{Glutationa Peroxidase (GPX)}

A atividade de GPX foi determinada pela aplicação do método descrito por McFarland et al. (1999). A atividade de GPX foi medida utilizando $1 \mathrm{mM}$ de hidroperóxido de cumeno como substrato, incubado a $30^{\circ} \mathrm{C}$ por 2 minutos. A GPX foi mensurada pela absorbância a $340 \mathrm{~nm}$ a cada 50 segundos durante $5 \mathrm{~min}$. Os resultados foram expressos como pmol.min ${ }^{-1} \cdot \mathrm{mg}^{-1}$ de proteína total.

\subsubsection{Peroxidação lipídica (LPO)}

A análise de peroxidação lipídica foi realizada mediante o método do ácido tiobarbitúrico (Wills, 1987). Esta determinação foi realizada através da fluorescência empregando $516 \mathrm{~nm}$ (excitação) e $600 \mathrm{~nm}$ (emissão). Os brancos e os padrões de tetrametoxipropano foram preparados em solução de homogeneização. Os resultados foram expressos em $\mu \mathrm{M}$ TBARs. $\mathrm{mg}^{-1}$ de proteínas. 


\subsubsection{Danos em DNA}

Os danos no DNA (strand breaks) foram avaliados por meio do ensaio de precipitação alcalina, baseado na precipitação, por meio de solução K-SDS, de lise celular, da ligação cruzada DNA-proteína, seguido por detecção de cadeias de DNA (Gagné et al., 1995). Padrões de DNA de esperma de salmão foram utilizados para a calibração. As leituras de fluorescência foram tomadas a $360 \mathrm{~nm}$ (excitação) e $450 \mathrm{~nm}$ (emissão). Os resultados foram expressos como $\mu \mathrm{g}$ DNA.mg-1 de proteína total.

\subsubsection{Colinesterase (ChE)}

A atividade da ChE foi determinada utilizando o método descrito por Ellman et al. (1961) e adaptado por Guilhermino et al. (1996). As enzimas ChE foram degradadas por meio do ácido DTNB (5-5'-ditiobis-(2-nitrobenzóico)). A absorbância foi medida a 405 nm a cada 1 minuto durante 7 minutos. Os resultados foram expressos como $\mathrm{nmol}$ de DTNB. $\mathrm{min}^{-1} \cdot \mathrm{mg}^{-1}$ de proteína total.

\subsubsection{Enzimas ciclooxigenases (COX)}

A atividade de ciclooxigenase (COX) foi controlada por meio da medição da oxidação do substrato 2,7 - dichlorofluorescein na presença de araquidonato (Fujimoto et al., 2002), em um ensaio que consiste na mistura de $50 \mu \mathrm{M}$ de araquidonato, $2 \mu \mathrm{M}$ de dichlorofluorescein e $0,1 \mu \mathrm{g} \cdot \mathrm{mL}^{-1}$ de horseradish peroxidase, em tampão de $50 \mathrm{mM}$ de Tris- $\mathrm{HCl}(\mathrm{pH} 8)$ contendo $0,05 \%$ de Tween-20. A fluorescência foi medida a $485 \mathrm{~nm}$ (excitação) e $530 \mathrm{~nm}$ (emissão). Os dados foram expressos como RFU.min ${ }^{-1} \cdot \mathrm{mg}^{-1}$ de proteína.

\subsubsection{Avaliação dos resultados dos ensaios de toxicidade}

A análise dos resultados dos ensaios de toxicidade para avaliação de efeitos crônicos com o mexilhão Perna perna e com o ouriço-do-mar Lytechinus variegatus, e dos ensaios de citotoxicidade com Mytella charruana seguiram os procedimentos adotados pela USEPA (2002). 
As análises estatísticas para avaliação dos efeitos crônicos e citotóxicos foram realizadas a partir do software TOXSTAT 3.5 (WEST \& GULLEY, 1996) para determinação da CENO, que significa a maior concentração dos compostos onde não foram observados efeitos estatisticamente significativos, e também na determinação da CEO, que se refere a menor concentração dos compostos onde efeitos foram observados durante o período do ensaio.

Para o estabelecimento da CENO e da CEO, os dados foram analisados quanto à normalidade e homogeneidade de variância pelos métodos Chi-square e Barttlett, respectivamente. Posteriormente, os dados foram submetidos ao método de análise de variância (ANOVA $-\mathrm{p}<0,05)$ por meio do método de Dunnett. O fluxograma abaixo apresenta as etapas para determinação da CENO e CEO nos ensaios de toxicidade (Figura 19).

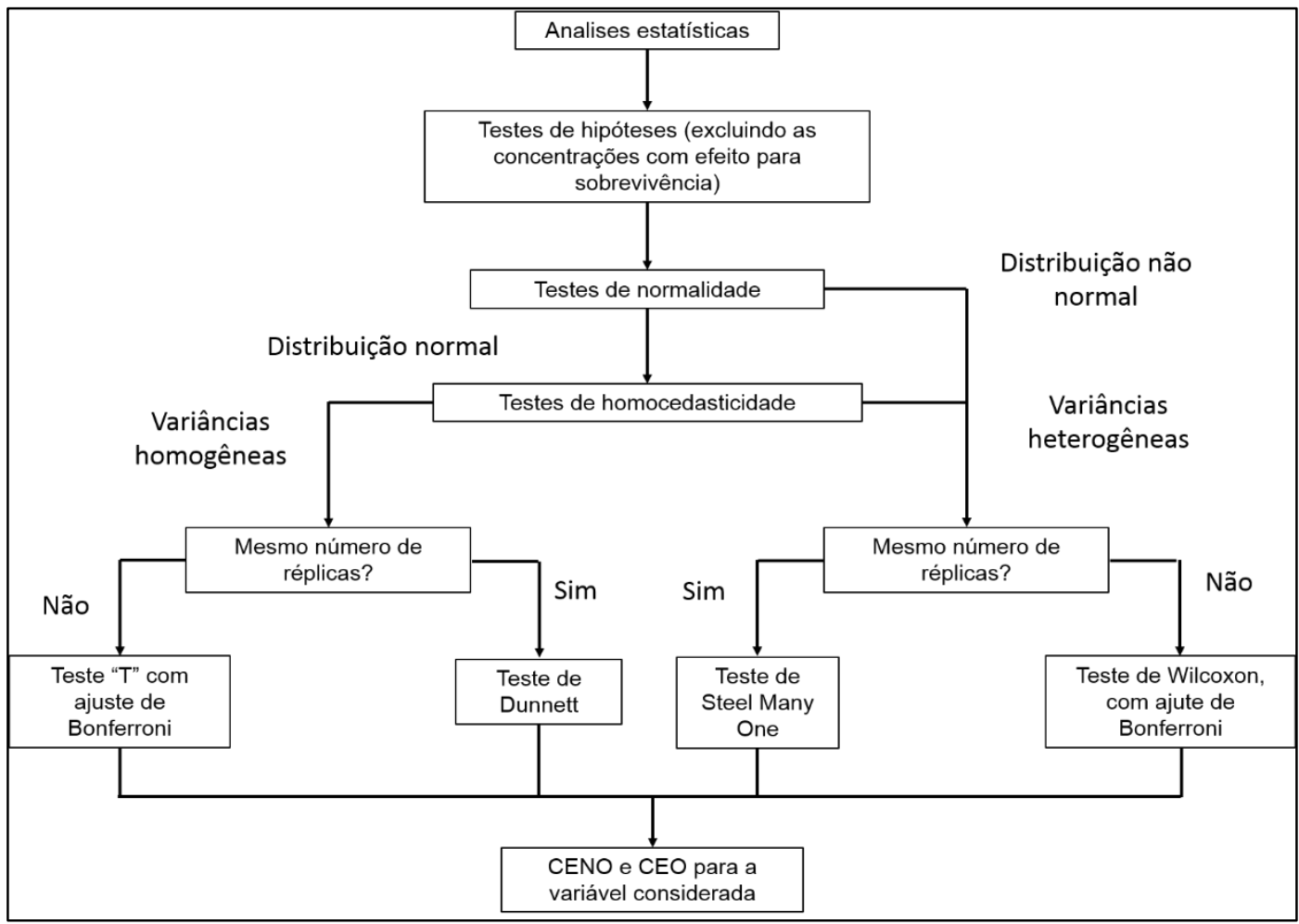

FIGURA 19 - Fluxograma com as etapas para o cálculo da CENO e CEO (USEPA, 2002). 


\subsection{Avaliação de risco ambiental}

O risco ambiental representado pelo triclosan, ibuprofeno e 17a-etinilestradiol nos ecossistemas aquáticos foram avaliados por meio do cálculo de quocientes de risco (QR), de acordo com protocolo da Comissão Europeia (EMEA, 2006). Os valores dos quocientes de risco para organismos aquáticos foram calculados a partir da razão entre as concentrações ambientais mensuradas em amostras de sedimentos coletadas no entorno do Emissário Submarino de Santos (MECs) e as concentrações onde não são previstos efeitos (PNECs) dos compostos farmacêuticos (Figura 20). Os PNECs foram calculados por meio da razão entre as menores concentrações de efeito não observado (CENO) nos ensaios, por um fator de avaliação correspondente a 10, que é uma expressão do grau de incerteza na extrapolação dos dados dos ensaios de toxicidade, considerando o princípio de prevenção e precaução. O critério de classificação aplicado foi: $Q R<1$ significa baixo risco, e $Q R \geq 1$ significa alto risco ambiental (EMEA, 2006).

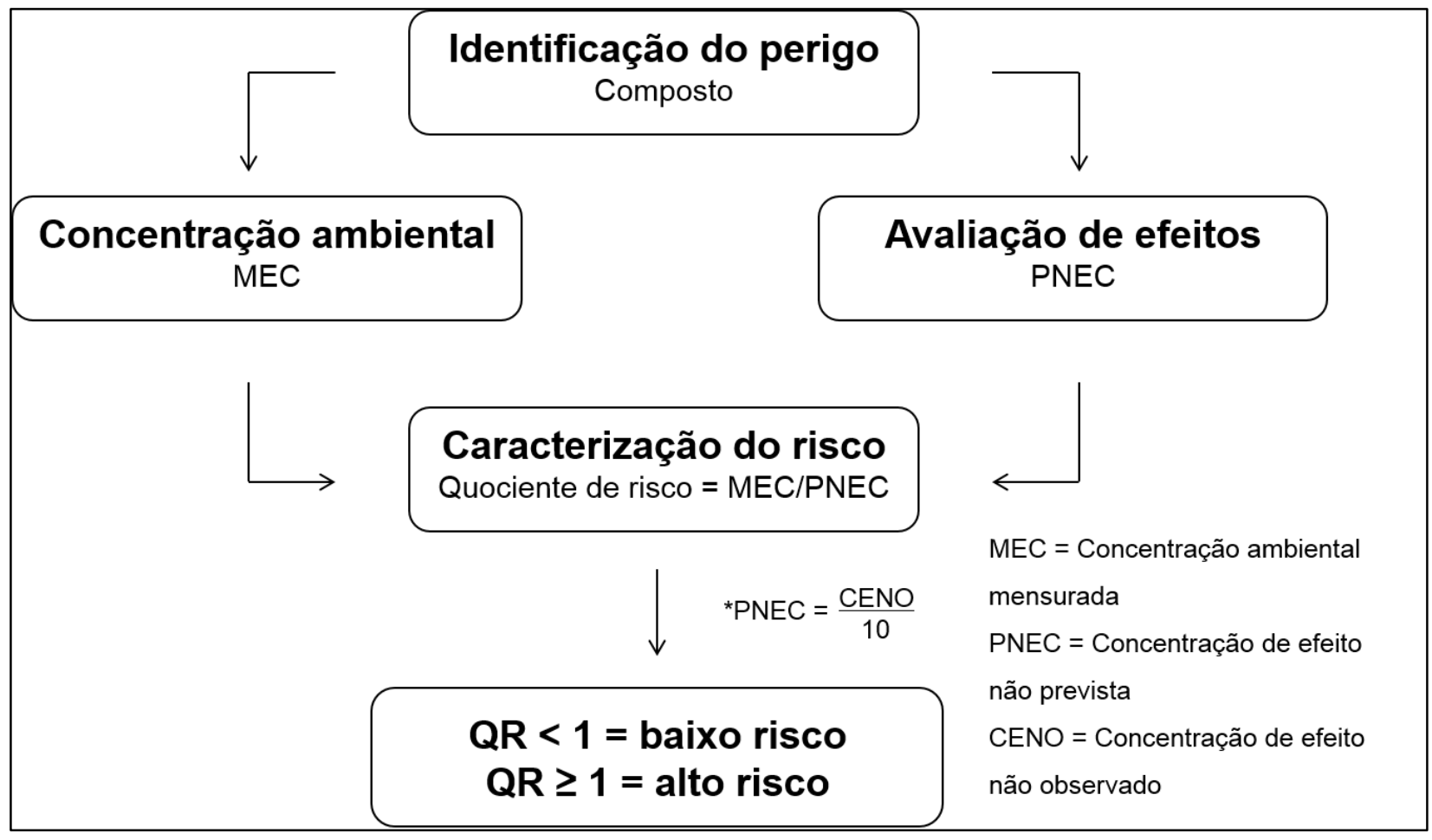

FIGURA 20 - Caracterização do risco ambiental elaborado a partir da Diretiva da EMEA (2006) 


\section{RESULTADOS}

\subsection{Avaliação ecotoxicológica dos sedimentos}

\subsubsection{Caracterização sedimentológica}

Os resultados da análise dos sedimentos da área controle (Toque Toque Grande) referentes à umidade, matéria orgânica e carbonatos, foram de $24,5 \%, 0,36 \%$ e $22,1 \%$, respectivamente. Além disso, foi evidenciada uma composição de $7,6 \%$ de areia grossa, $27,7 \%$ de areia média, $56,8 \%$ de areia fina e $7,2 \%$ de areia muito fina. Os resultados obtidos pelas análises encontram-se descritos na Tabela 6 .

TABELA 6 - Caracterização do sedimento (Toque Toque Grande, São Sebastião - SP) de acordo com a escala de Wentworth (1922).

\begin{tabular}{lccc}
\hline Granulometria (mm) & Massa $(\mathbf{g})$ & Porcentagem (\%) & Nome do Material \\
\hline Massa inicial & 100 & - & - \\
Maior que 2,0 & - & - & - \\
2,0 a 1,0 & - & - & - \\
1,0 a 0,5 & 7,65 & 7,6 & Areia grossa \\
0,5 a 0,25 & 27,63 & 27,7 & Areia média \\
0,25 a 0,125 & 56,75 & 56,8 & Areia fina \\
0,125 a 0,063 & 0,72 & 0,7 & Areia muito fina \\
Menor que 0,063 & 7,23 & 7,2 & Silte/Argila \\
Total & 99,98 & 100,0 & - \\
\hline
\end{tabular}

\subsubsection{Análises químicas}

A linearidade e a exatidão do método analítico foram avaliadas utilizando amostras de sedimentos não contaminados e enriquecidos com diferentes níveis de concentração de cada composto. Na Fig. 21 são apresentados os cromatogramas obtidos para os compostos analisados, e na Fig. 22 as representações gráficas da linearidade. Os 
resultados de exatidão observados nas curvas analíticas para o TCS, IBU e EE2 estão apresentados nas Tabelas 7, 8 e 9, respectivamente. Os dados de recuperação obtidos encontraram-se em uma faixa de variação de 34-100\% (triclosan - 100\%; ibuprofeno $88 \%$; 17a-etinilestradiol - 34\%), e podem ser considerados aceitáveis de acordo com os critérios adotados pela Comissão Europeia (EC, 2010) e a USEPA (2007).

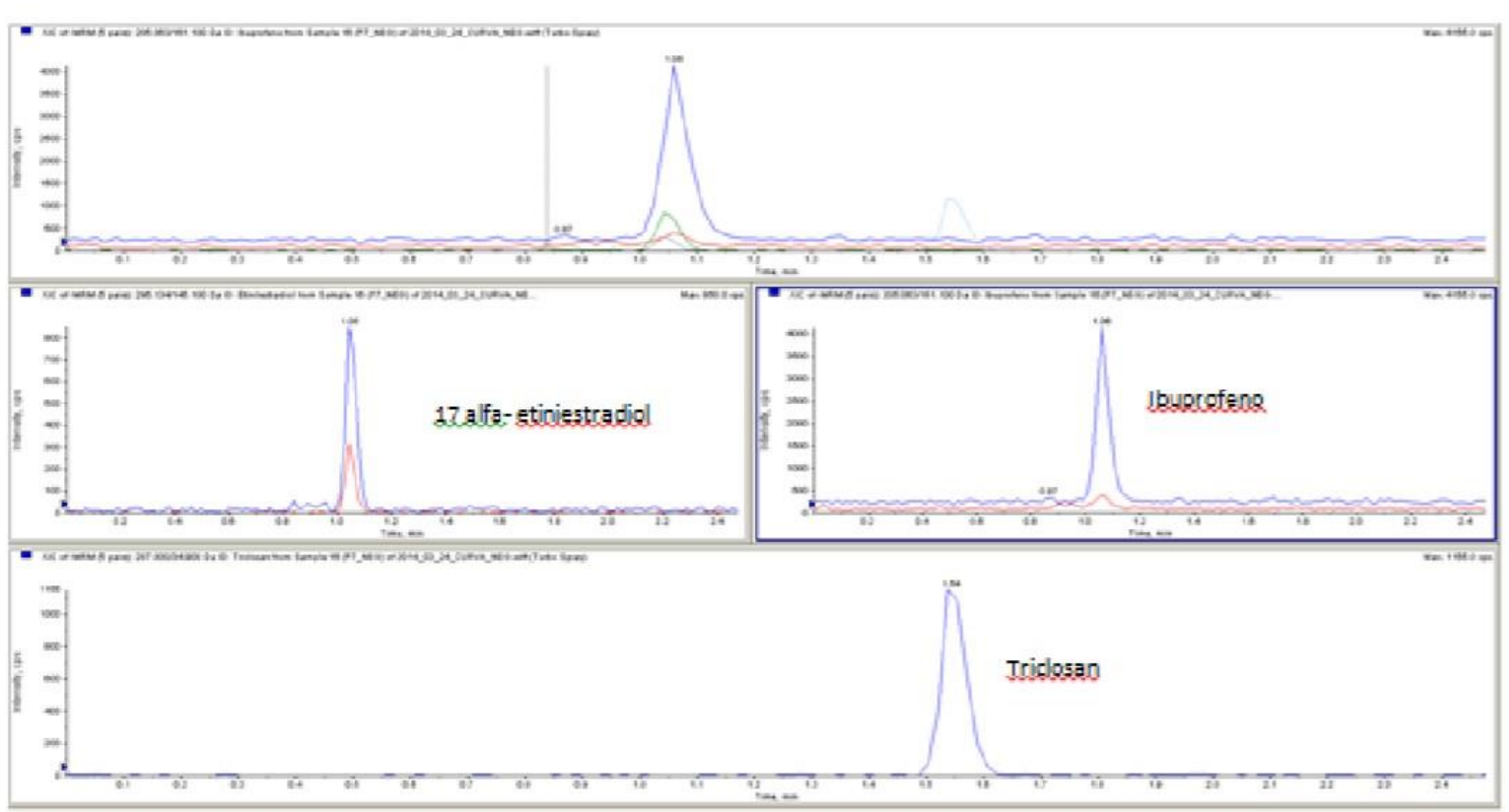

FIGURA 21 - Cromatogramas obtidos para TCS, IBU e EE2 no modo negativo 

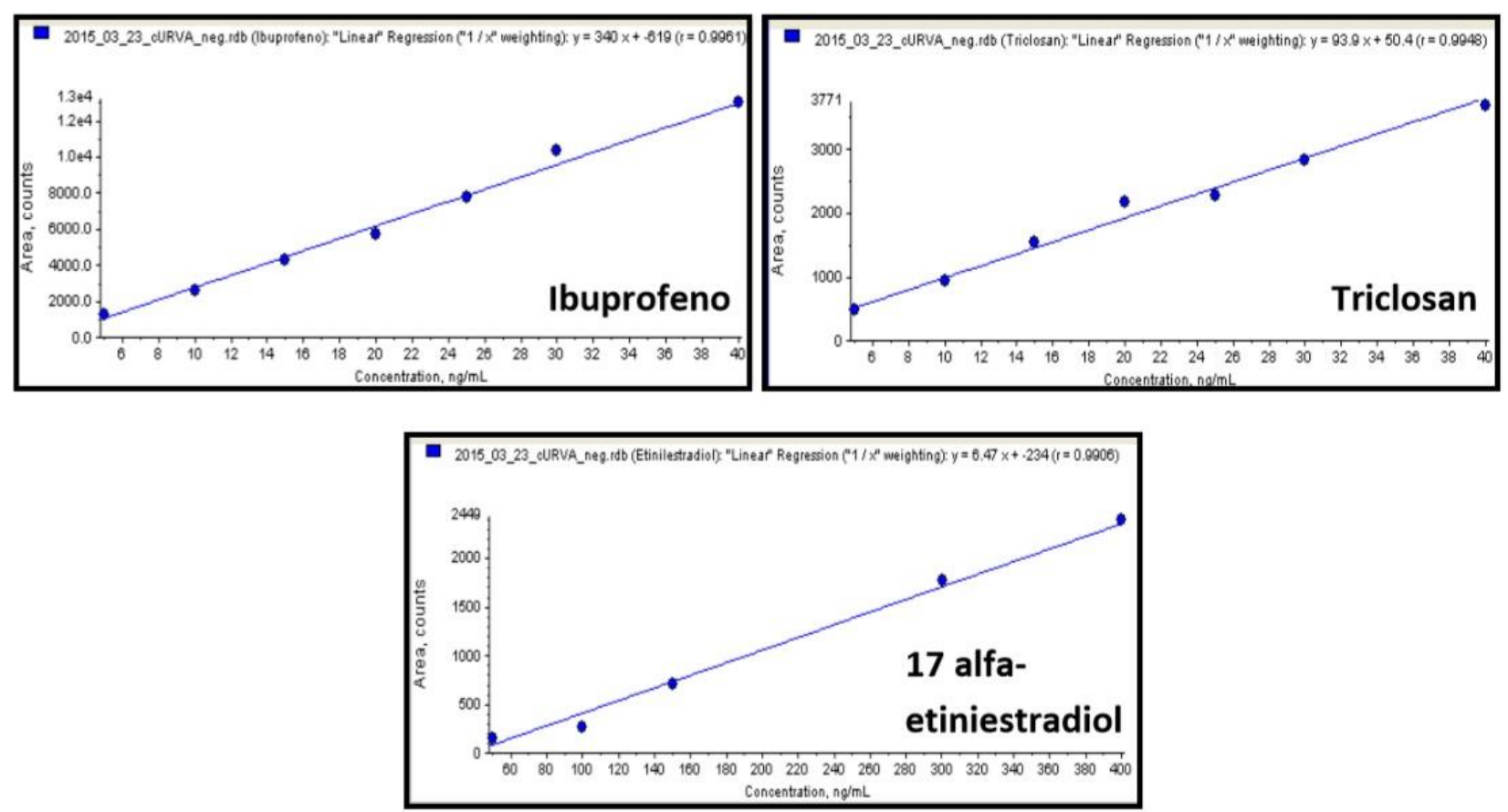

FIGURA 22 - Representações gráficas da linearidade para os compostos analisados

TABELA 7 - Resultados de exatidão observada para os pontos considerados nas curvas analíticas para o triclosan no modo negativo.

\begin{tabular}{cccccc}
\hline Área do pico & Altura do \\
Pontos & $\begin{array}{c}\text { Triclosan } \\
\text { (counts) }\end{array}$ & $\begin{array}{c}\text { Concentração do } \\
\text { analito (cps) }\end{array}$ & $\begin{array}{c}\text { Concentração } \\
\text { real }\left(\mathbf{n g} \cdot \mathbf{g}^{-1}\right)\end{array}$ & $\begin{array}{c}\text { experimental } \\
\left(\mathbf{n g} \cdot \mathbf{g}^{-1}\right)\end{array}$ & $\begin{array}{c}\text { Exatidão } \\
\text { (\%) }\end{array}$ \\
\hline P1 & $4,93 \mathrm{E}+02$ & $1,21 \mathrm{E}+02$ & 5 & 4,72 & 94,4 \\
P2 & $9,52 \mathrm{E}+02$ & $2,32 \mathrm{E}+02$ & 10 & 9,6 & 96 \\
P3 & $1,54 \mathrm{E}+03$ & $3,77 \mathrm{E}+02$ & 15 & 15,8 & 106 \\
P4 & $2,17 \mathrm{E}+03$ & $5,22 \mathrm{E}+02$ & 20 & 22,6 & 113 \\
P5 & $2,28 \mathrm{E}+03$ & $5,39 \mathrm{E}+02$ & 25 & 23,8 & 95,1 \\
P6 & $2,83 \mathrm{E}+03$ & $6,85 \mathrm{E}+02$ & 30 & 29,6 & 98,8 \\
P7 & $3,69 \mathrm{E}+03$ & $9,03 \mathrm{E}+02$ & 40 & 38,8 & 97,1 \\
\hline
\end{tabular}


TABELA 8 - Resultados de exatidão observada para os pontos considerados nas curvas analíticas para o ibuprofeno no modo negativo.

\begin{tabular}{cccccc}
\hline Área do pico & Altura do \\
Pontos & $\begin{array}{c}\text { Ibuprofeno } \\
\text { (counts) }\end{array}$ & $\begin{array}{c}\text { Concentração } \\
\text { analito }(\mathbf{c p s})\end{array}$ & $\begin{array}{c}\text { Concentração } \\
\text { real }\left(\mathbf{n g} \cdot \mathbf{g}^{-1}\right)\end{array}$ & $\begin{array}{c}\text { experimental } \\
\left(\mathbf{n g} \cdot \mathbf{g}^{-1}\right)\end{array}$ & $\begin{array}{c}\text { Exatidão } \\
\text { (\%) }\end{array}$ \\
\hline P1 & $1,26 \mathrm{E}+03$ & $3,18 \mathrm{E}+02$ & 5 & 5,53 & 111 \\
P2 & $2,57 \mathrm{E}+03$ & $6,61 \mathrm{E}+02$ & 10 & 9,39 & 93,9 \\
P3 & $4,27 \mathrm{E}+03$ & $9,89 \mathrm{E}+02$ & 15 & 14,4 & 95,8 \\
P4 & $5,70 \mathrm{E}+03$ & $1,25 \mathrm{E}+03$ & 20 & 18,6 & 92,9 \\
P5 & $7,79 \mathrm{E}+03$ & $1,48 \mathrm{E}+03$ & 25 & 24,7 & 99 \\
P6 & $1,03 \mathrm{E}+04$ & $2,02 \mathrm{E}+03$ & 30 & 32,2 & 107 \\
P7 & $1,30 \mathrm{E}+04$ & $2,87 \mathrm{E}+03$ & 40 & 40,2 & 100 \\
\hline
\end{tabular}

TABELA 9 - Resultados de exatidão observada para os pontos considerados nas curvas analíticas para o 17a-etinilestradiol no modo negativo.

\begin{tabular}{cccccc}
\hline \multicolumn{7}{c}{ 17a-etinilestradiol } \\
Pontos & $\begin{array}{c}\text { Área do pico } \\
\text { do analito } \\
\text { (counts) }\end{array}$ & $\begin{array}{c}\text { Altura do } \\
\text { pico do } \\
\text { analito (cps) }\end{array}$ & $\begin{array}{c}\text { Concentração } \\
\text { real }\left(\mathbf{n g} \cdot \mathbf{g}^{-1}\right)\end{array}$ & $\begin{array}{c}\text { Concentração } \\
\text { experimental } \\
\left(\mathbf{n g} \cdot \mathbf{g}^{-1}\right)\end{array}$ & $\begin{array}{c}\text { Exatidão } \\
\text { (\%) }\end{array}$ \\
\hline P1 & $1,56 \mathrm{E}+02$ & $3,50 \mathrm{E}+01$ & 50 & 63,7 & 127 \\
P2 & $2,66 \mathrm{E}+02$ & $6,12 \mathrm{E}+01$ & 100 & 82,4 & 82,4 \\
P3 & $7,10 \mathrm{E}+02$ & $1,25 \mathrm{E}+02$ & 150 & 158 & 105 \\
P4 & $1,77 \mathrm{E}+03$ & $4,02 \mathrm{E}+02$ & 300 & 338 & 113 \\
P5 & $2,40 \mathrm{E}+03$ & $6,15 \mathrm{E}+02$ & 400 & 444 & 111 \\
\hline
\end{tabular}

A TAB. 10 apresenta os limites de detecção (LD) e quantificação (LQ) do método, e os resultados das análises na amostra de sedimento coletada no entorno do ESS. 
TABELA 10 - Parâmetros de operação MRM no modo de ionização negativo, Limites de detecção, limites de quantificação, tempo de retenção e concentração dos FPCP nas amostras de sedimentos do ESS (ng.g ${ }^{-1}$ peso seco).

\begin{tabular}{|c|c|c|c|c|c|c|c|c|c|}
\hline \multirow{2}{*}{ Composto } & \multirow{2}{*}{ Q1 } & \multirow{2}{*}{ Q3 } & \multirow{2}{*}{$\begin{array}{l}\text { DP } \\
\text { (V) }\end{array}$} & \multirow{2}{*}{$\begin{array}{l}\text { CE } \\
\text { (V) }\end{array}$} & \multirow{2}{*}{$\operatorname{CXP}(\mathrm{V})$} & \multicolumn{2}{|c|}{ 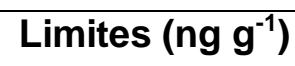 } & \multirow{2}{*}{$\begin{array}{c}\text { TR } \\
(\min )\end{array}$} & \multirow{2}{*}{$\begin{array}{c}\text { Concentração } \\
\left(\mathrm{ng} \mathrm{g}^{-1}\right)(\mathrm{n}=3)\end{array}$} \\
\hline & & & & & & LD & LQ & & \\
\hline \multirow[t]{2}{*}{ Triclosan } & 287,0 & 34,9 & -40 & -29 & -3 & 0,42 & 1,4 & 1,54 & 15,14 \\
\hline & & (MIM) & & & & & & & \\
\hline \multirow[t]{2}{*}{ Ibuprofeno } & 205,0 & 161,1 & -15 & -10 & -2 & 2,12 & 7,09 & 4,65 & 49,0 \\
\hline & & 159,0 & -15 & -10 & -2 & & & & \\
\hline \multirow[t]{2}{*}{ EE2 } & 295,1 & 145,1 & -65 & -54 & -2 & 33,3 & 111,1 & 1,05 & $<L D$ \\
\hline & & 199,1 & -65 & -52 & -2 & & & & \\
\hline
\end{tabular}

Q1 (first quadrupole); Q3 (last quadrupole); DP (Declustering Potential); CE (Collision Energy); CXP (Collision Exit Potential); LD (Limite de detecção: Sinal/ruído = 3); LQ (Limite de quantificação: Sinal/ruído = 10); TR (Tempo de retenção); MIM (Multiple lon Monitoring). Em Q3, a célula superior indica o íon quantificador e a inferior o íon qualificador.

As Figuras 23 e 24 apresentam os cromatogramas, operados no modo de aquisição negativo, com os picos para TCS e IBU obtidos na amostra de sedimento do ESS, respectivamente. O EE2 não foi detectado na amostra coletada.

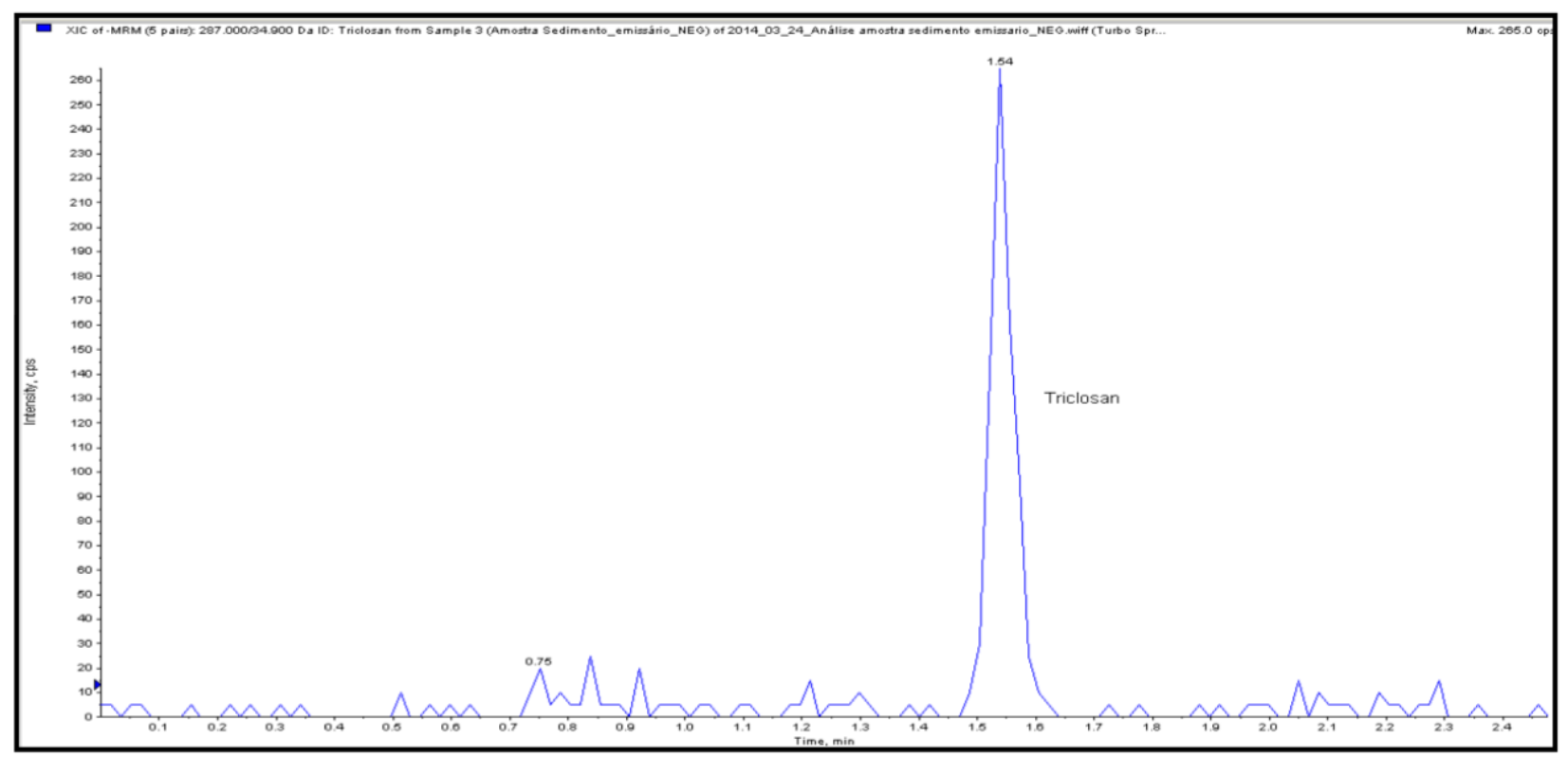

FIGURA 23 - Cromatograma obtido no modo de aquisição negativo para a amostra de sedimento do emissário submarino (TCS). 


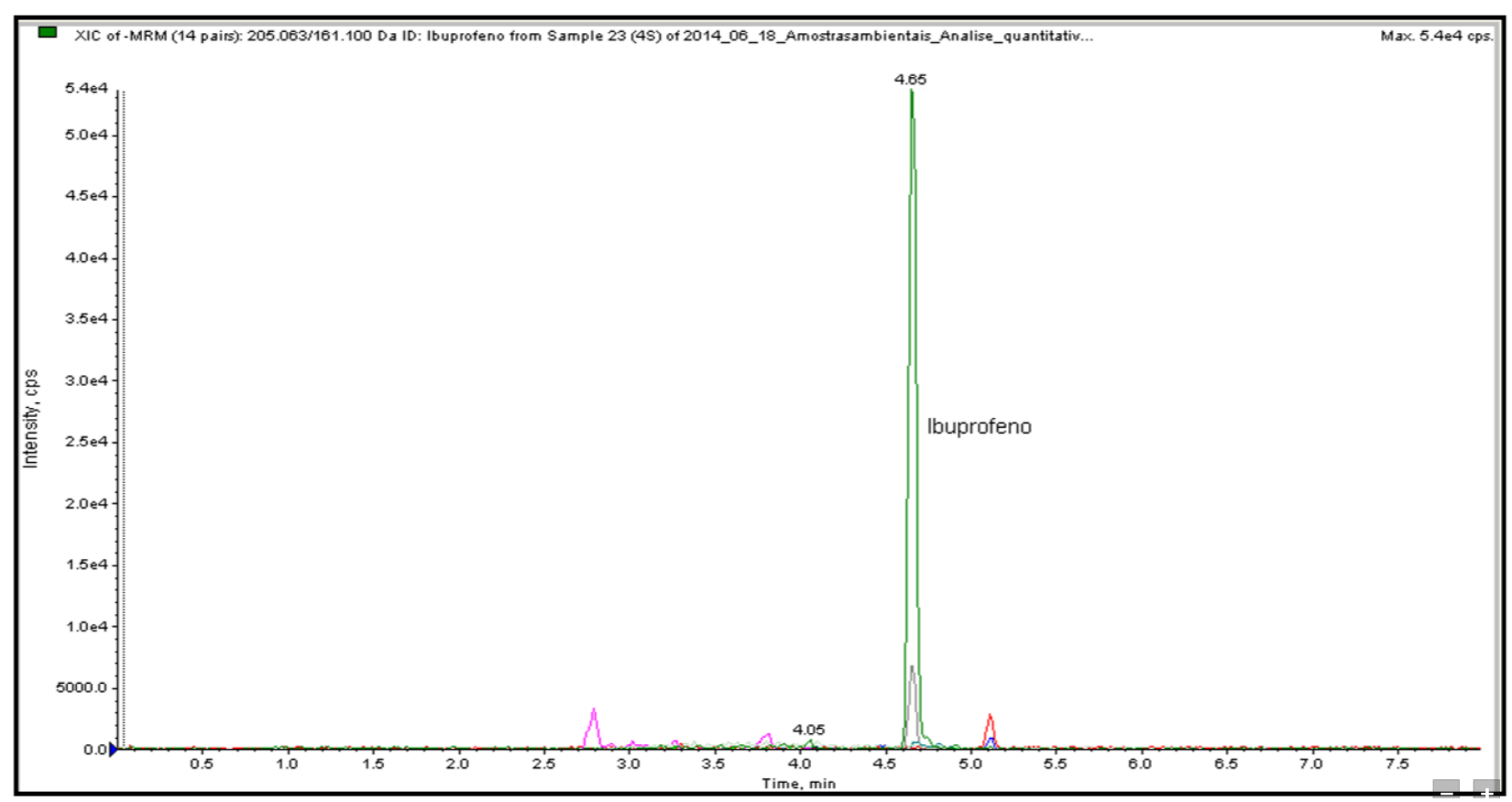

FIGURA 24 - Cromatograma obtido no modo de aquisição negativo para a amostra de sedimento do emissário submarino (IBU).

\subsubsection{Resultado dos ensaios de toxicidade}

\subsubsection{Resultado dos ensaios de toxicidade com Perna perna}

Em paralelo aos experimentos, foram realizados ensaios de sensibilidade $(n=2)$ com os mexilhões Perna perna para se verificar a viabilidade dos embriões utilizados nos ensaios. Os resultados da Cl50;48h foram de 1,01 mg.L-1 $\left(0,97-1,03 \mathrm{mg} \cdot \mathrm{L}^{-1}\right)$ e 1,09 $\left(1,07-1,11 \mathrm{mg} \cdot \mathrm{L}^{-1}\right)$ de DSS. Os resultados obtidos nos ensaios de sensibilidade ao DSS encontram-se dentro do intervalo de concentrações reportadas na literatura (Zaroni, 2005; Simm, 2009; Cortez, 2011).

Os resultados dos ensaios de toxicidade para avaliação dos efeitos crônicos de sedimentos contaminados com triclosan, em embriões do mexilhão Perna perna, apresentaram valores de CENO e CEO de 7,502 e 75,02 ng. f $^{-1}$, respectivamente, nos ensaios com interface sedimento-água ( $n=3$ ) (Fig. 25), e CENO e CEO de 75,02 e 750,2 ng. $g^{-1}$ com as amostras de elutriato ( $n=3$ ) (Fig. 26). 

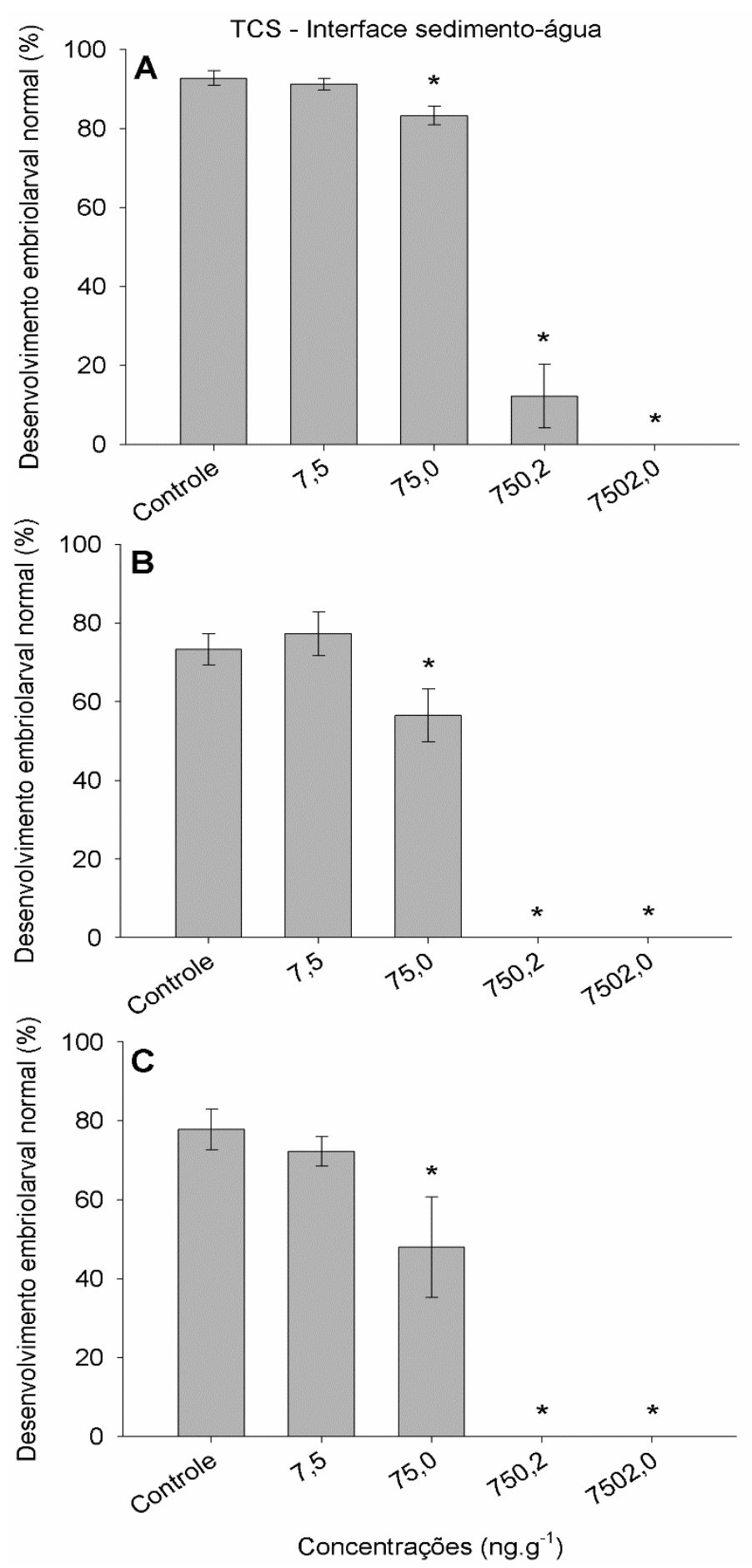

FIGURA 25 - Resultado dos ensaios de toxicidade do TCS (interface sedimento-água) para o mexilhão $P$. perna após 48 horas de exposição ao sedimento marcado (ng.g $\left.{ }^{-1}\right)$. A = Ensaio 1; $\mathrm{B}=$ Ensaio 2; $\mathrm{C}=$ Ensaio 3 . *Diferença significativa em relação ao controle (ANOVA $-p \leq 0,05)$. 

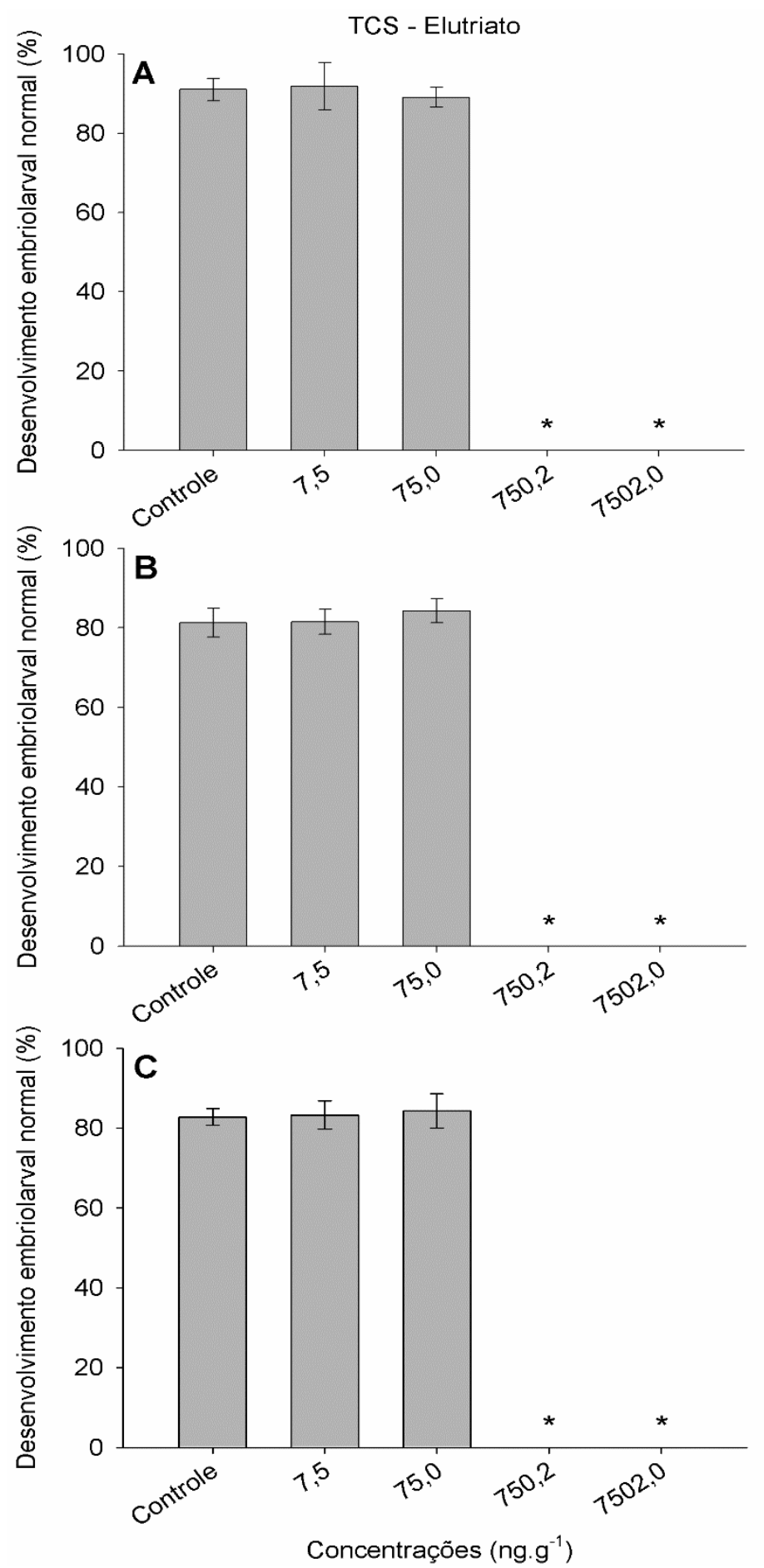

FIGURA 26 - Resultado dos ensaios de toxicidade do TCS (elutriato) para o mexilhão $P$. perna após 48 horas de exposição ao sedimento marcado $\left(\mathrm{ng} \cdot \mathrm{g}^{-1}\right) . \mathrm{A}=$ Ensaio $1 ; \mathrm{B}=$ Ensaio 2; $\mathrm{C}=$ Ensaio 3. ${ }^{*}$ Diferença significativa em relação ao controle (ANOVA $-p \leq$ $0,05)$. 
Os resultados dos ensaios com IBU apresentaram valores de CENO e CEO de 1,508 e 15,08 $\mathrm{ng} \cdot \mathrm{g}^{-1}$, respectivamente, nos ensaios com interface sedimento-água $(\mathrm{n}=2)$ (Fig. 27), e CENO e CEO de 15,08 e 150,8 ng. $\mathrm{g}^{-1}$ com as amostras de elutriato $(n=3)$ (Fig. 28).

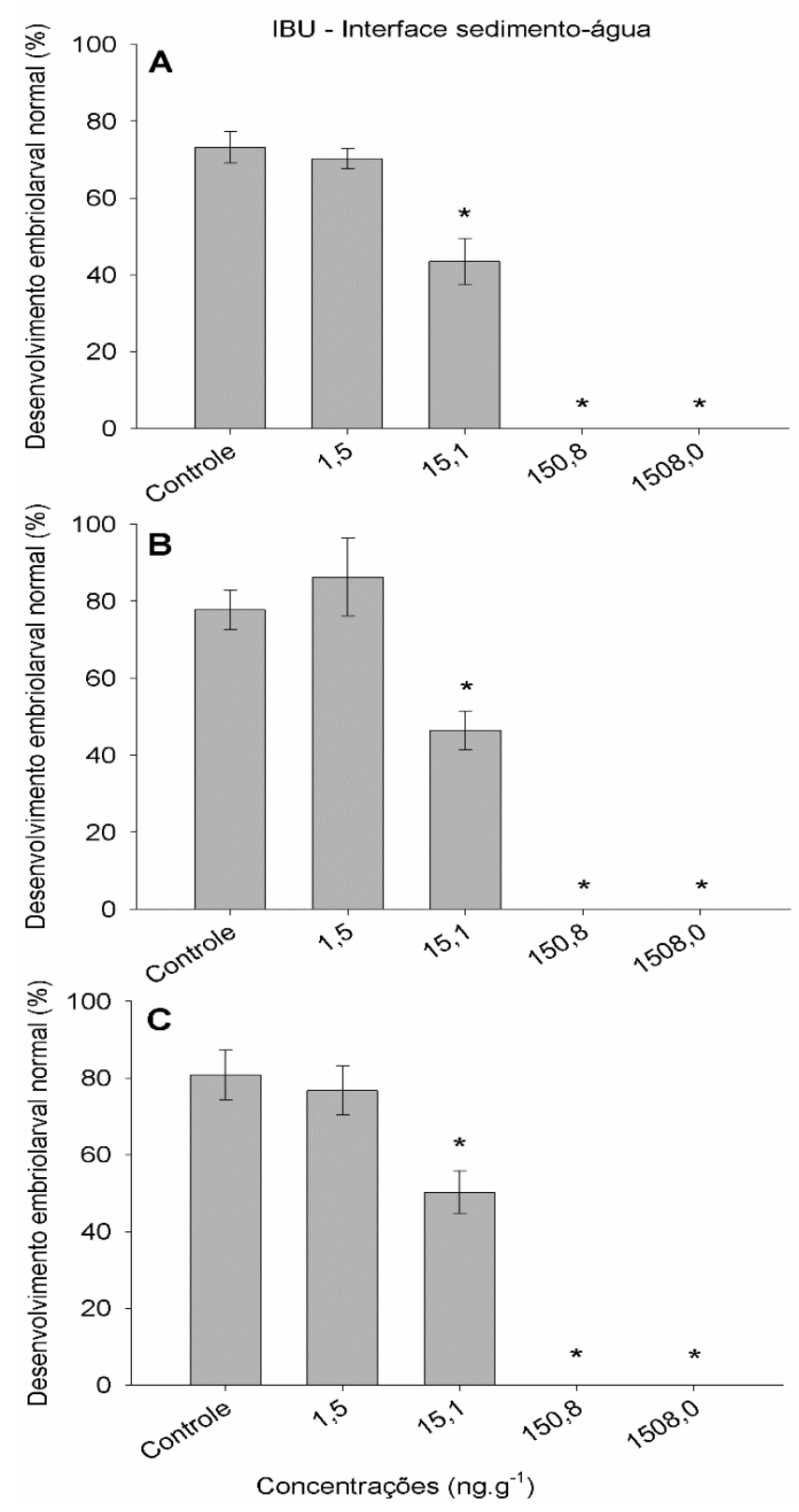

FIGURA 27 - Resultado dos ensaios de toxicidade do IBU (interface sedimento-água) para o mexilhão $P$. perna após 48 horas de exposição ao sedimento marcado (ng. $\left.\mathrm{g}^{-1}\right)$. A = Ensaio 1; $\mathrm{B}=$ Ensaio 2; $\mathrm{C}=$ Ensaio 3 . *Diferença significativa em relação ao controle (ANOVA - $p \leq 0,05$ ). 

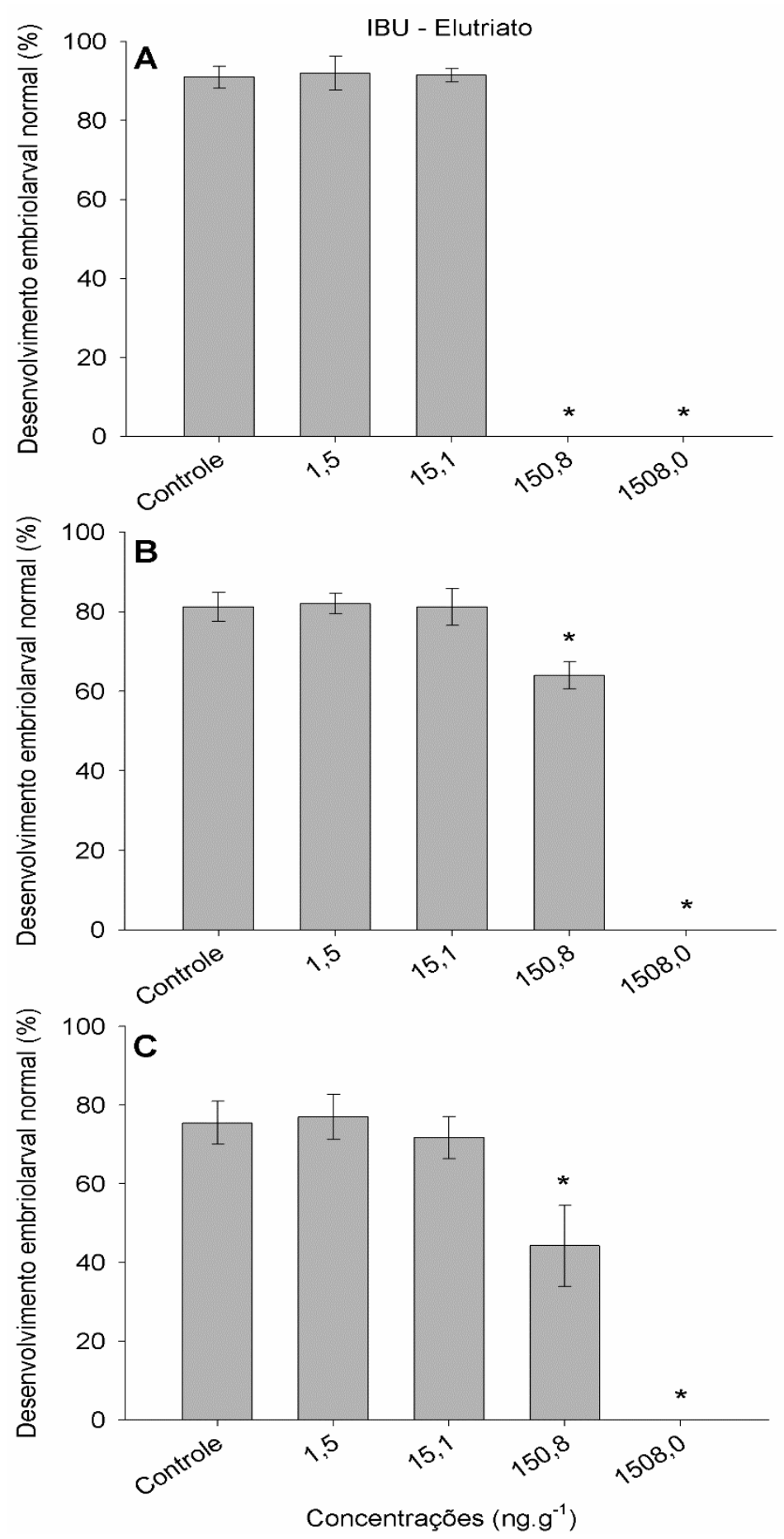

FIGURA 28 - Resultado dos ensaios de toxicidade do IBU (elutriato) para o mexilhão $P$. perna após 48 horas de exposição ao sedimento marcado $\left(\mathrm{ng} \cdot \mathrm{g}^{-1}\right) . \mathrm{A}=$ Ensaio $1 ; \mathrm{B}=$ Ensaio 2; $\mathrm{C}=$ Ensaio 3 . *Diferença significativa em relação ao controle (ANOVA $-p \leq$ $0,05)$. 
Com relação aos resultados dos ensaios com EE2, os valores de CENO e CEO foram de 0,237 e 2,37 $\mathrm{ng}^{-\mathrm{g}^{-1}}$, respectivamente, nos ensaios com interface sedimentoágua $(n=2)$ (Fig. 29). As amostras de elutriato $(n=3)$ apresentaram valores de CENO e CEO de 0,237 e 2,37 ng.g-1 , respectivamente (Fig. 30).

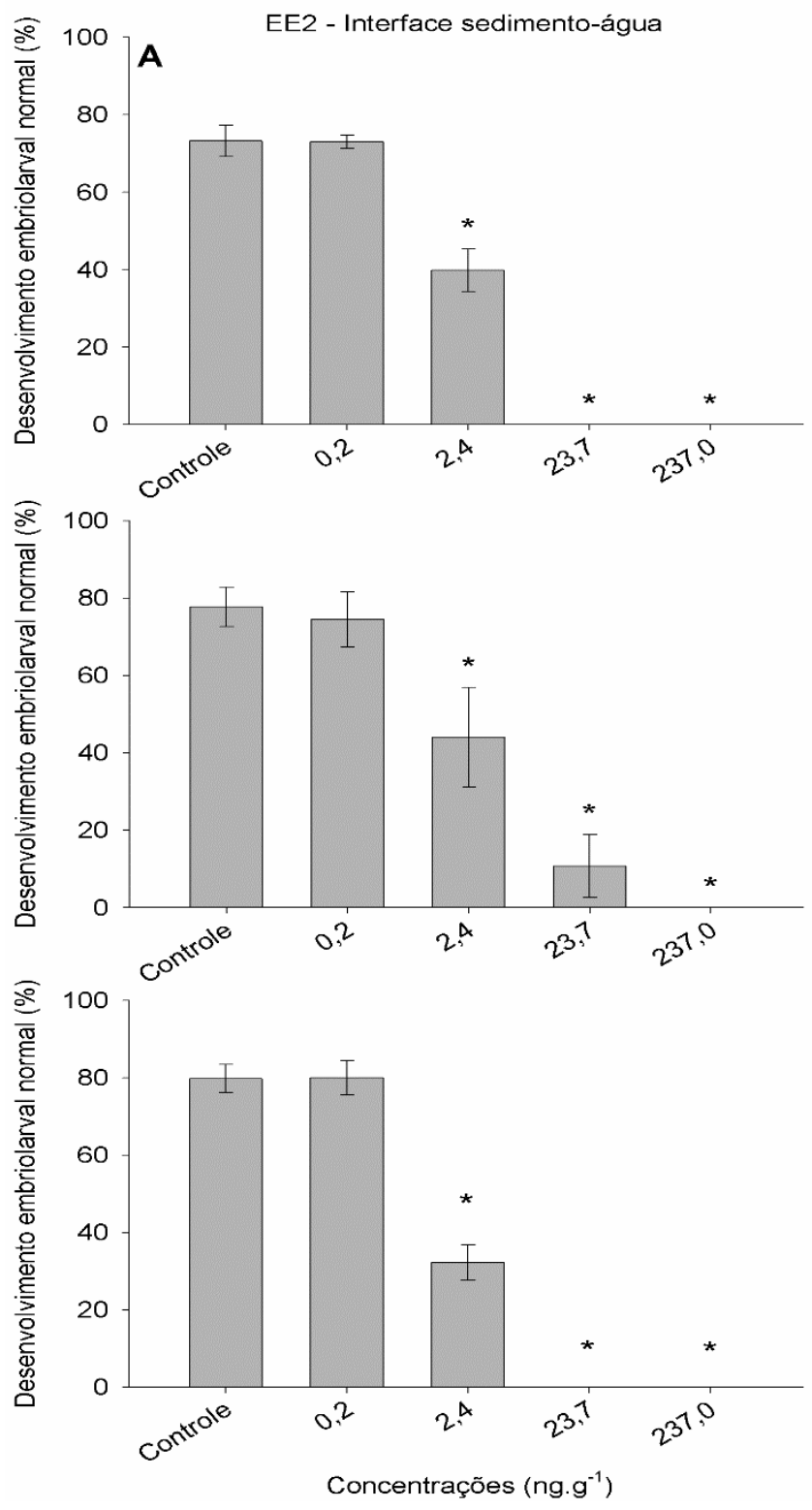

FIGURA 29 - Resultado dos ensaios de toxicidade do EE2 (interface sedimento-água) para o mexilhão $P$. perna após 48 horas de exposição ao sedimento marcado (ng. $\left.g^{-1}\right)$. A = Ensaio 1; $\mathrm{B}=$ Ensaio 2; $\mathrm{C}=$ Ensaio 3 . *Diferença significativa em relação ao controle (ANOVA - $p \leq 0,05)$. 


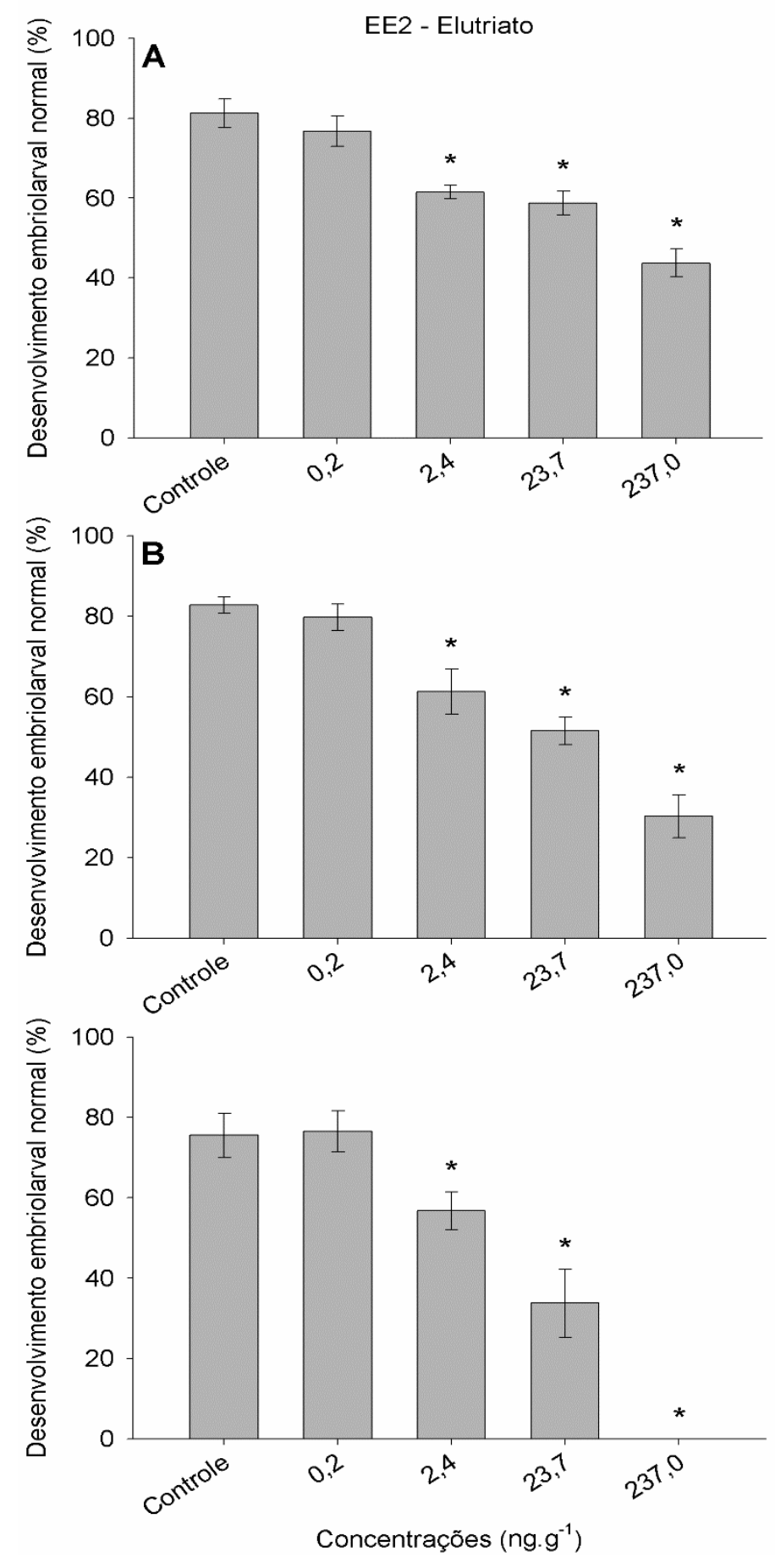

FIGURA 30 - Resultado dos ensaios de toxicidade do EE2 (elutriato) para o mexilhão $P$. perna após 48 horas de exposição ao sedimento marcado $\left(\mathrm{ng} \cdot \mathrm{g}^{-1}\right) . \mathrm{A}=$ Ensaio $1 ; \mathrm{B}=$ Ensaio 2; $\mathrm{C}=$ Ensaio 3. ${ }^{*}$ Diferença significativa em relação ao controle (ANOVA $-p \leq$ $0,05)$. 
Os resultados das análises físico-químicas (salinidade, $\mathrm{pH}$ e oxigênio dissolvido) dos ensaios com interface sedimento-água e elutriato estiveram dentro dos limites de tolerância para espécie.

\subsubsection{Resultado dos ensaios de toxicidade com Lytechinus variegatus}

Foram realizados ensaios de sensibilidade $(n=2)$ com os ouriços-do-mar, em paralelo aos experimentos, para se verificar a viabilidade dos embriões utilizados nos ensaios. Os resultados da Cl50;24h e os respectivos intervalos de confiança foram de $0,50 \mathrm{mg} \cdot \mathrm{L}^{-1}\left(0,50 \mathrm{mg} \cdot \mathrm{L}^{-1}-0,52 \mathrm{mg} \cdot \mathrm{L}^{-1}\right)$ e $0,54 \mathrm{mg} \cdot \mathrm{L}^{-1}\left(0,53 \mathrm{mg} \cdot \mathrm{L}^{-1}-0,56 \mathrm{mg} \cdot \mathrm{L}^{-1}\right)$ de Sulfato de Zinco $\left(\mathrm{ZnSO}_{4}\right)$. Estes valores encontraram-se dentro dos limites estabelecidos para espécie, de acordo com a carta-controle do Laboratório de Ecotoxicologia Prof. Caetano Belliboni - Universidade Santa Cecília.

Os resultados dos ensaios toxicidade para avaliação dos efeitos crônicos de sedimentos contaminados com TCS, em embriões do ouriço-do-mar Lytechinus variegatus, apresentaram valores de CENO e CEO de 7,502 e 75,02 ng.g-1, respectivamente, tanto nos ensaios com interface sedimento-água $(n=3)$ (Fig. 31), como nos ensaios com as amostras de elutriato ( $n=3$ ) (Fig. 32). 


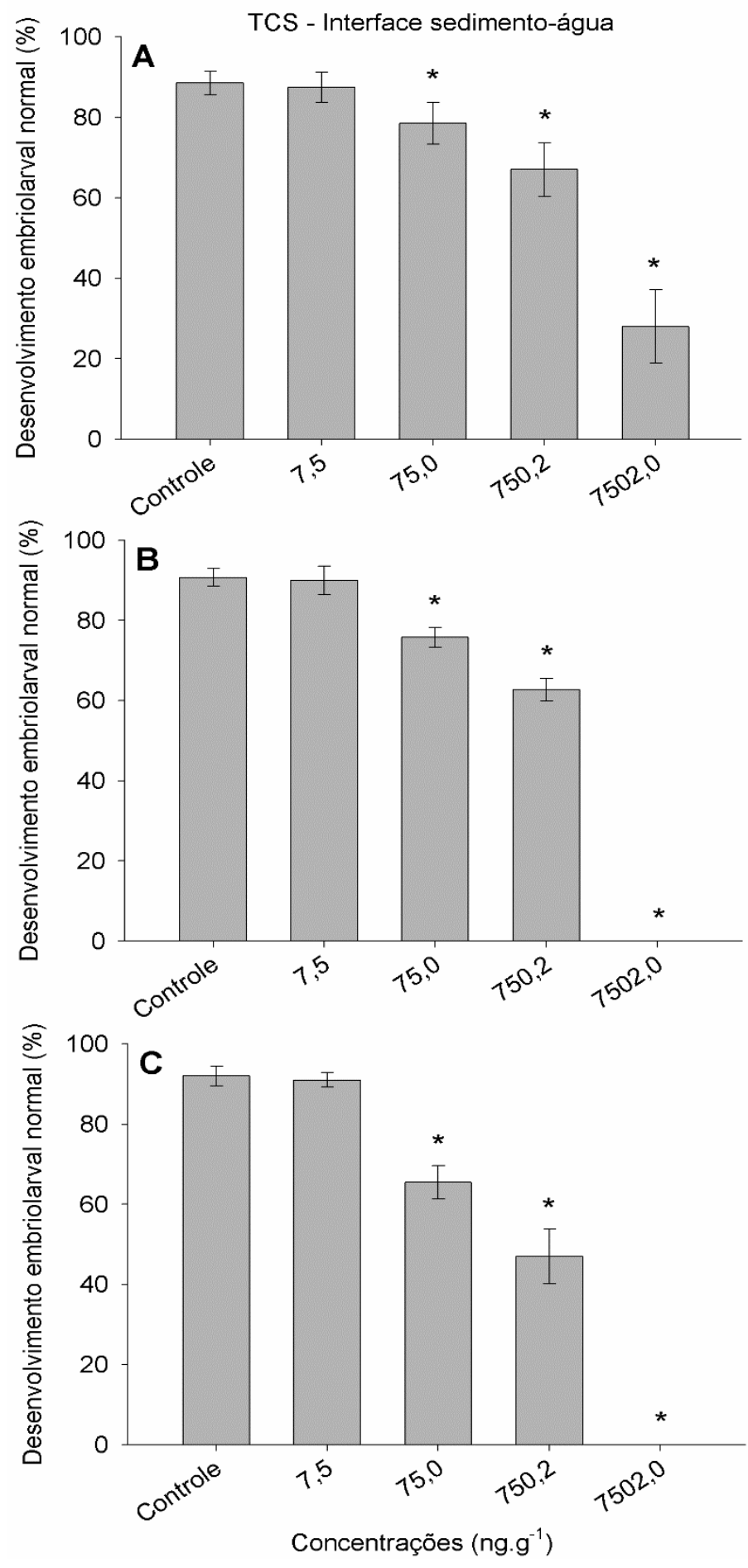

FIGURA 31 - Resultado dos ensaios de toxicidade do TCS (interface sedimentoágua) para $L$. variegatus após 24 horas de exposição ao sedimento marcado (ng. $\left.\mathrm{g}^{-1}\right)$. A = Ensaio 1; $\mathrm{B}=$ Ensaio 2; $\mathrm{C}=$ Ensaio 3 . ${ }^{*}$ Diferença significativa em relação ao controle (ANOVA $-p \leq 0,05)$. 

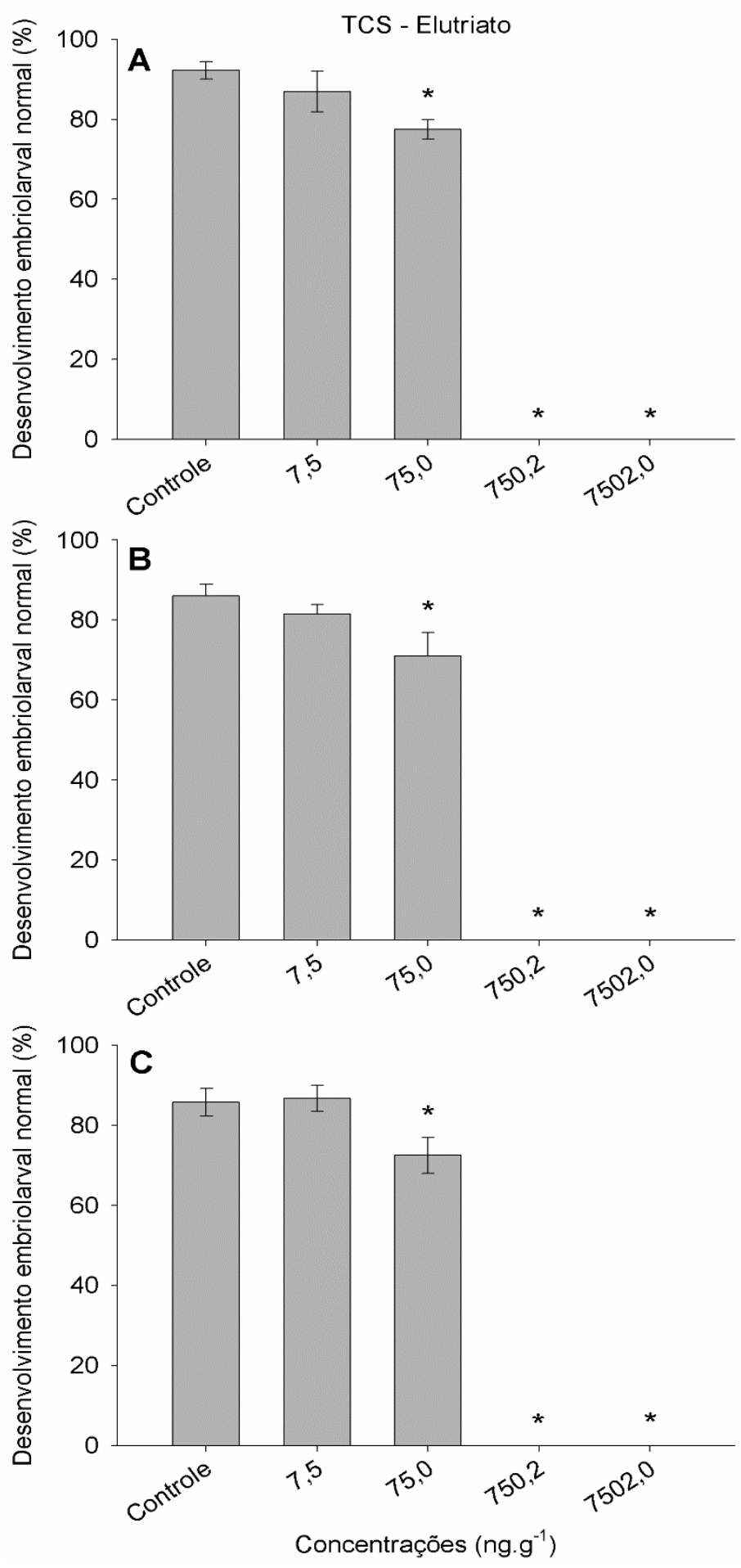

FIGURA 32 - Resultado dos ensaios de toxicidade do TCS (elutriato) para $L$. variegatus após 24 horas de exposição ao sedimento marcado (ng.g ${ }^{-1}$ ). $A=$ Ensaio 1 ; $B$ = Ensaio 2; $\mathrm{C}=$ Ensaio 3. *Diferença significativa em relação ao controle (ANOVA $-\mathrm{p} \leq$ 0,05). 
Os resultados dos ensaios com IBU apresentaram valores de CENO e CEO de 1,508 e 15,08 ng. $\mathrm{g}^{-1}$, respectivamente, nos ensaios com interface sedimento-água (Fig. 33) e com as amostras de elutriato (Fig. 34).
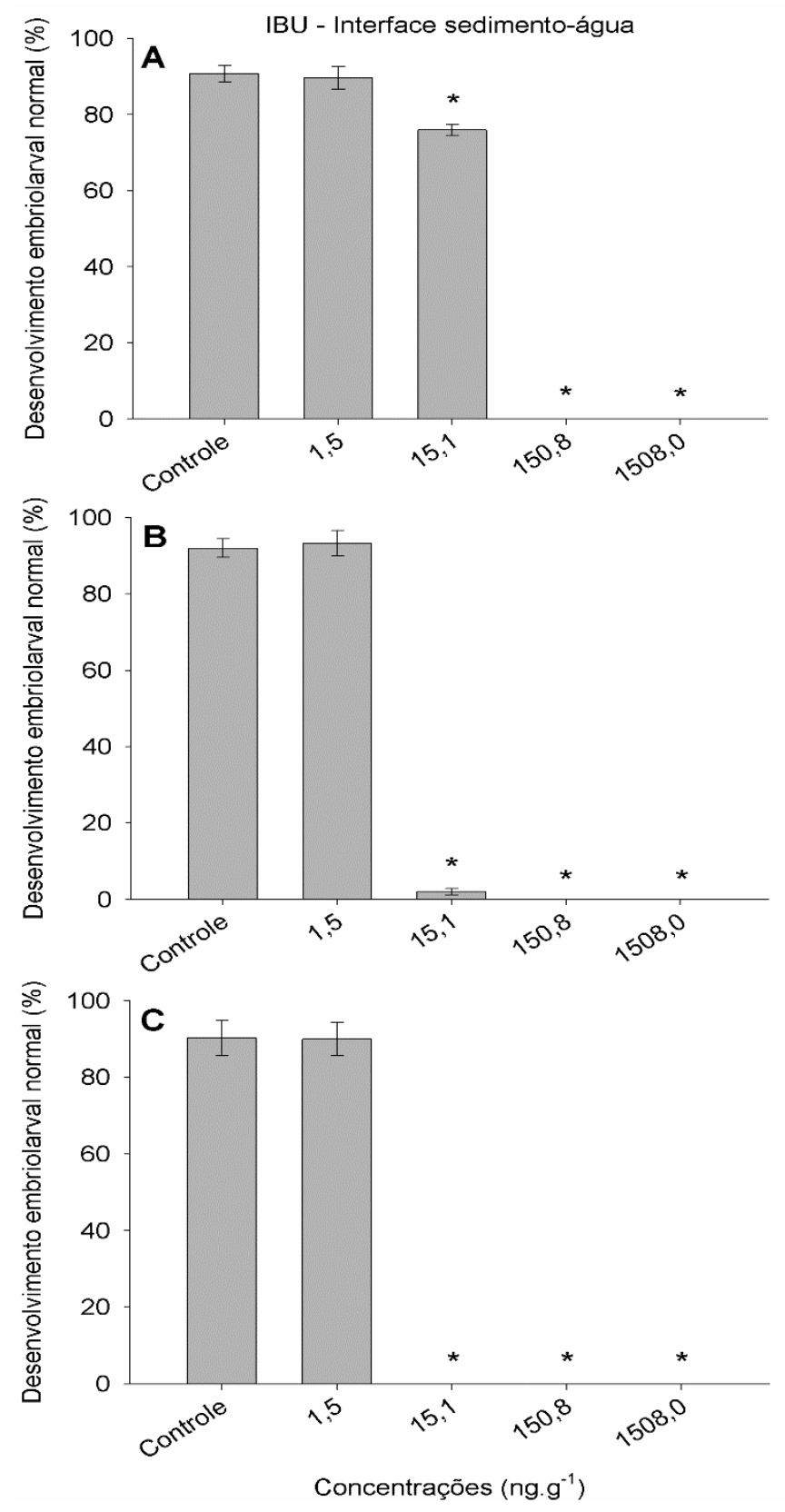

FIGURA 33 - Resultado dos ensaios de toxicidade do IBU (interface sedimentoágua) para $L$. variegatus após 24 horas de exposição ao sedimento marcado (ng.g $\left.{ }^{-1}\right)$. A = Ensaio 1; $\mathrm{B}=$ Ensaio 2; $\mathrm{C}=$ Ensaio 3. ${ }^{*}$ Diferença significativa em relação ao controle (ANOVA $-p \leq 0,05)$. 


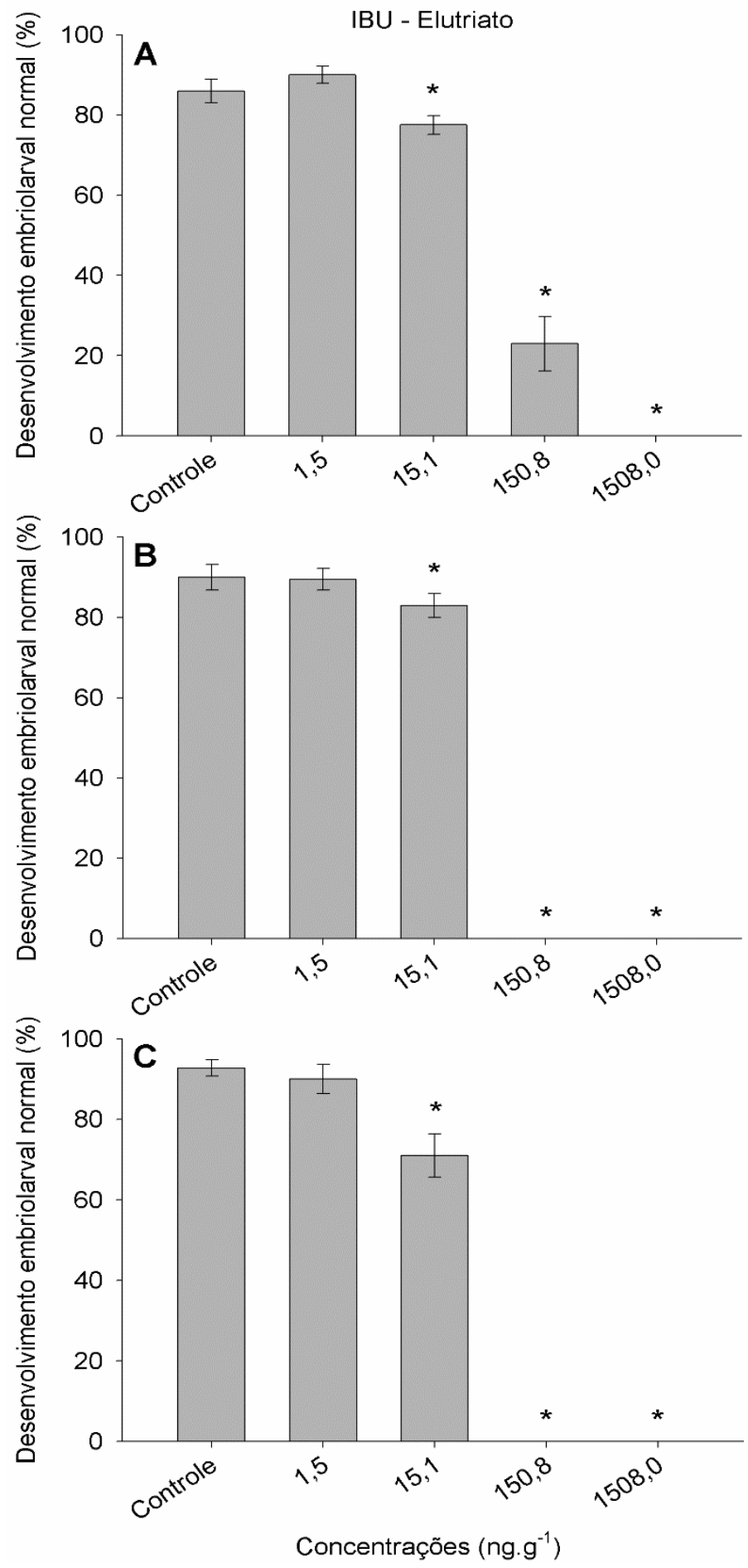

FIGURA 34 - Resultado dos ensaios de toxicidade do IBU (elutriato) para $L$. variegatus após 24 horas de exposição ao sedimento marcado $\left(\mathrm{ng} \cdot \mathrm{g}^{-1}\right) . \mathrm{A}=$ Ensaio 1 ; B $=$ Ensaio 2; $\mathrm{C}=$ Ensaio 3. * Diferença significativa em relação ao controle (ANOVA $-p \leq$ $0,05)$. 
Com relação aos resultados dos ensaios com EE2, os valores de CENO e CEO foram de 0,237 e 2,37 ng.g ${ }^{-1}$, tanto nos ensaios com interface sedimento-água ( $n=3$ ) (Fig. 35), quanto no ensaio com elutriato ( $n=3$ ) (Fig. 36).

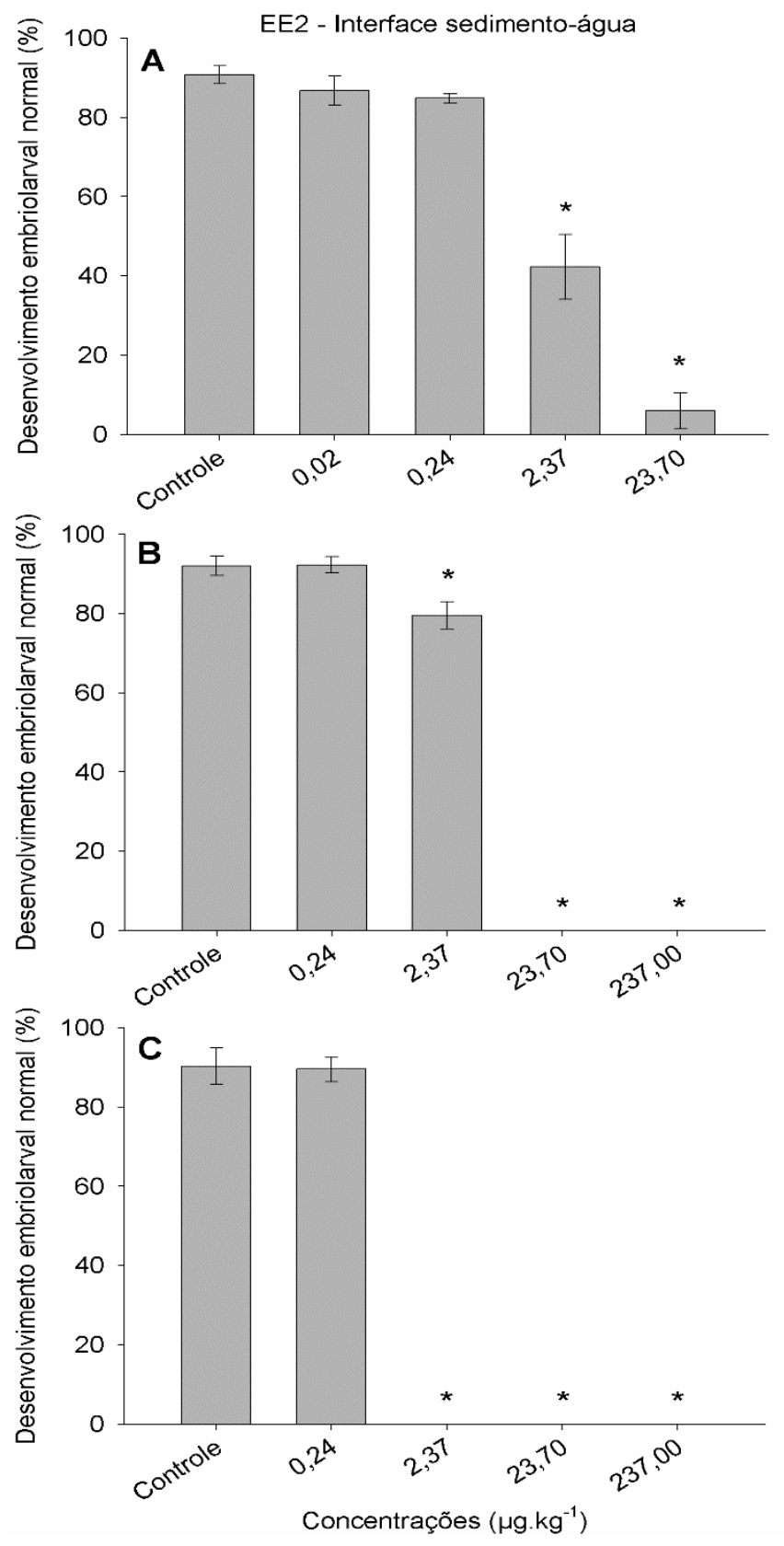

FIGURA 35 - Resultado dos ensaios de toxicidade do EE2 (interface sedimentoágua) para $L$. variegatus após 24 horas de exposição ao sedimento marcado (ng.g $\left.{ }^{-1}\right)$. A = Ensaio 1; $\mathrm{B}=$ Ensaio 2; $\mathrm{C}=$ Ensaio 3. *Diferença significativa em relação ao controle (ANOVA $-p \leq 0,05$ ). 

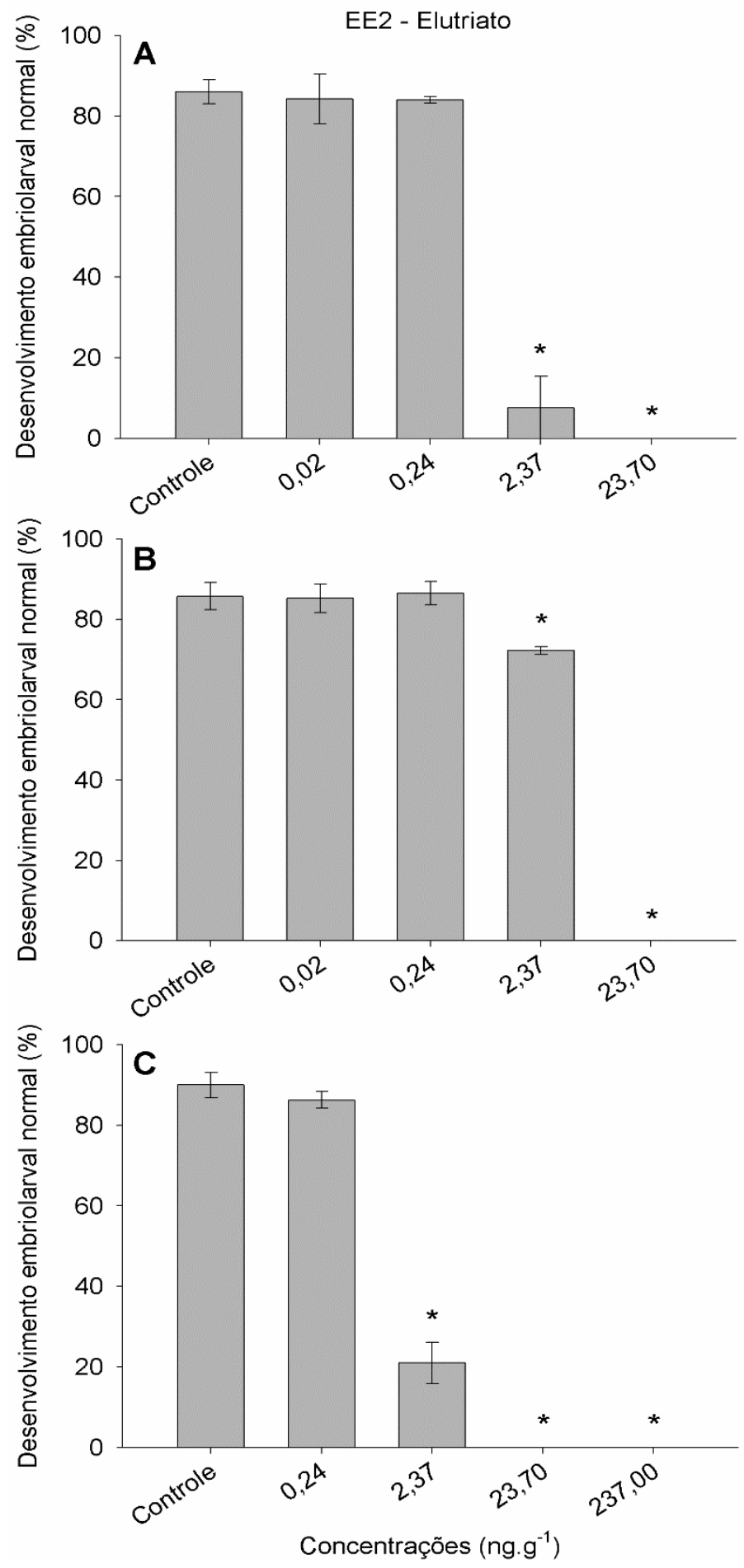

FIGURA 36 - Resultado dos ensaios de toxicidade do EE2 (elutriato) para $L$. variegatus após 24 horas de exposição ao sedimento marcado (ng.g ${ }^{-1}$ ). $A=$ Ensaio 1 ; $B$ = Ensaio 2; $\mathrm{C}=$ Ensaio 3. *Diferença significativa em relação ao controle (ANOVA $-\mathrm{p} \leq$ 0,05). 
Os resultados das análises físico-químicas (salinidade, $\mathrm{pH}$ e oxigênio dissolvido) dos ensaios com interface sedimento-água e elutriato estiveram dentro dos limites de tolerância para espécie.

\subsubsection{Resultado dos ensaios de citotoxicidade com Mytella charruana}

Os resultados dos ensaios de citotoxicidade com triclosan estão demonstrados na Figura 37. Após 24 horas de exposição, nos três ensaios realizados, o tempo de retenção do corante vermelho neutro nos lisossomos diminuiu significativamente nas concentrações de 0,08 e $0,75 \mathrm{ng} \cdot \mathrm{g}^{-1}$ quando comparado ao controle. 

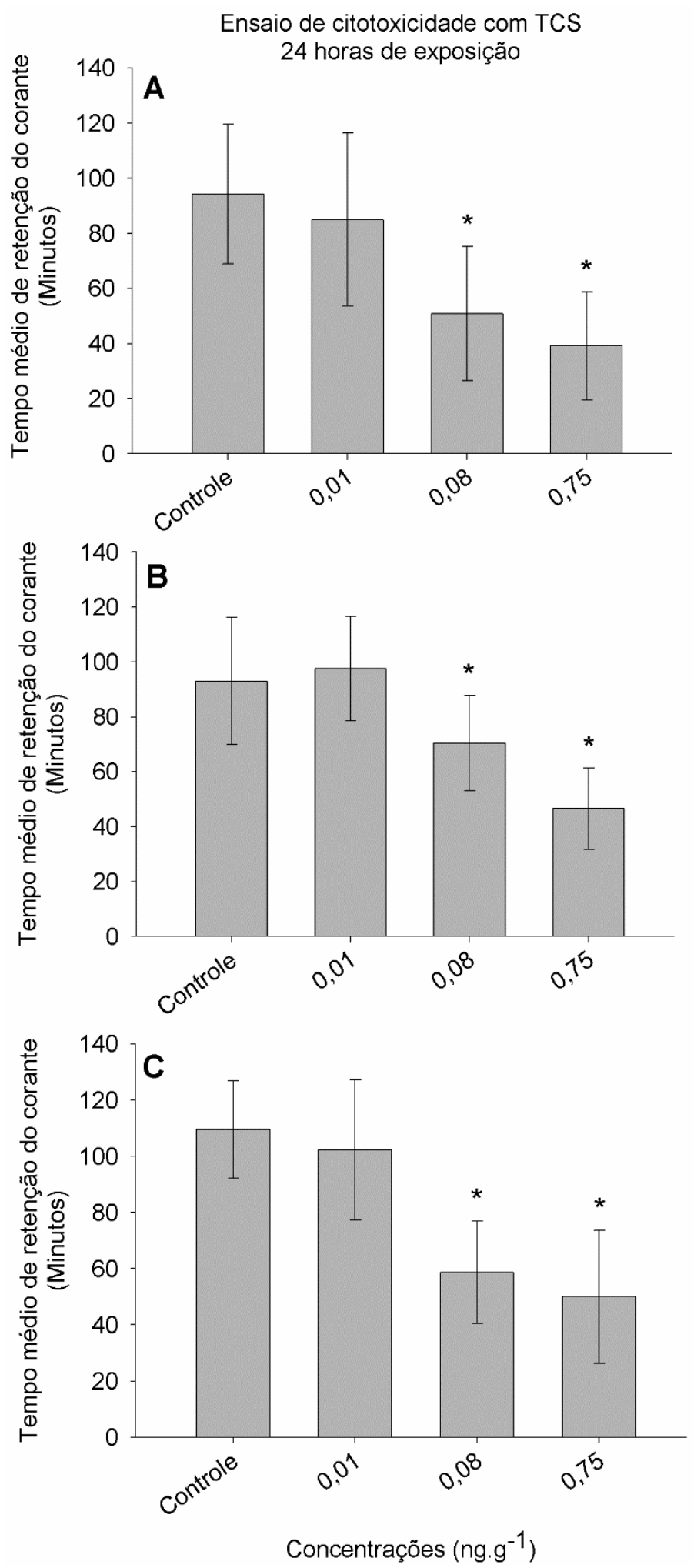

FIGURA 37 - Toxicidade do TCS em hemócitos do molusco bivalve Mytella charruana após 24 horas de exposição ao sedimento marcado $\left(n g \cdot g^{-1}\right)$. A = Ensaio 1; B = Ensaio 2; $C=$ Ensaio 3. *Diferença significativa em relação ao controle (ANOVA $-p \leq 0,05$ ). 
Os ensaios de citotoxicidade com ibuprofeno estão demonstrados na Fig. 38. Após 24 horas de exposição, nos três ensaios realizados, o tempo de retenção do corante vermelho neutro nos lisossomos diminuiu significativamente a partir da concentração de $0,15 \mathrm{ng} \cdot \mathrm{g}^{-1}$ quando comparado ao controle.
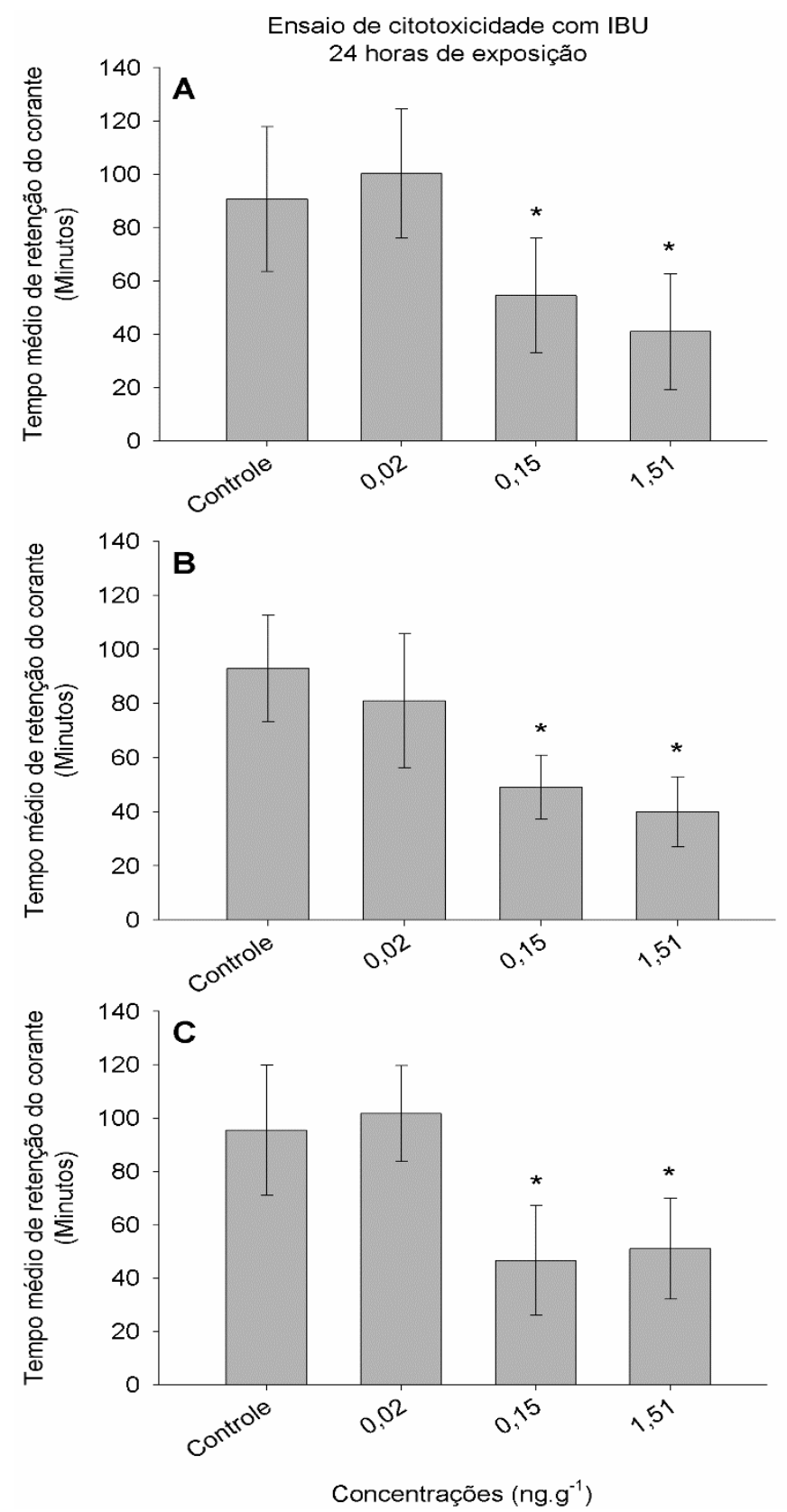

FIGURA 38 - Toxicidade do IBU em hemócitos do molusco bivalve Mytella charruana após 24 horas de exposição ao sedimento marcado $\left(n g \cdot g^{-1}\right)$. A = Ensaio 1; $B=$ Ensaio $2 ; \mathrm{C}=$ Ensaio 3. ${ }^{*}$ Diferença significativa em relação ao controle (ANOVA $-p \leq 0,05$ ). 
A Fig. 39 apresenta os resultados dos ensaios de citotoxicidade com 17aetinilestradiol após 24 horas de exposição do $M$. charruana. Nos três ensaios realizados, o tempo de retenção do corante vermelho neutro nos lisossomos diminuiu significativamente na concentração de $0,024 \mathrm{ng} \cdot \mathrm{g}^{-1}$ quando comparado ao controle.

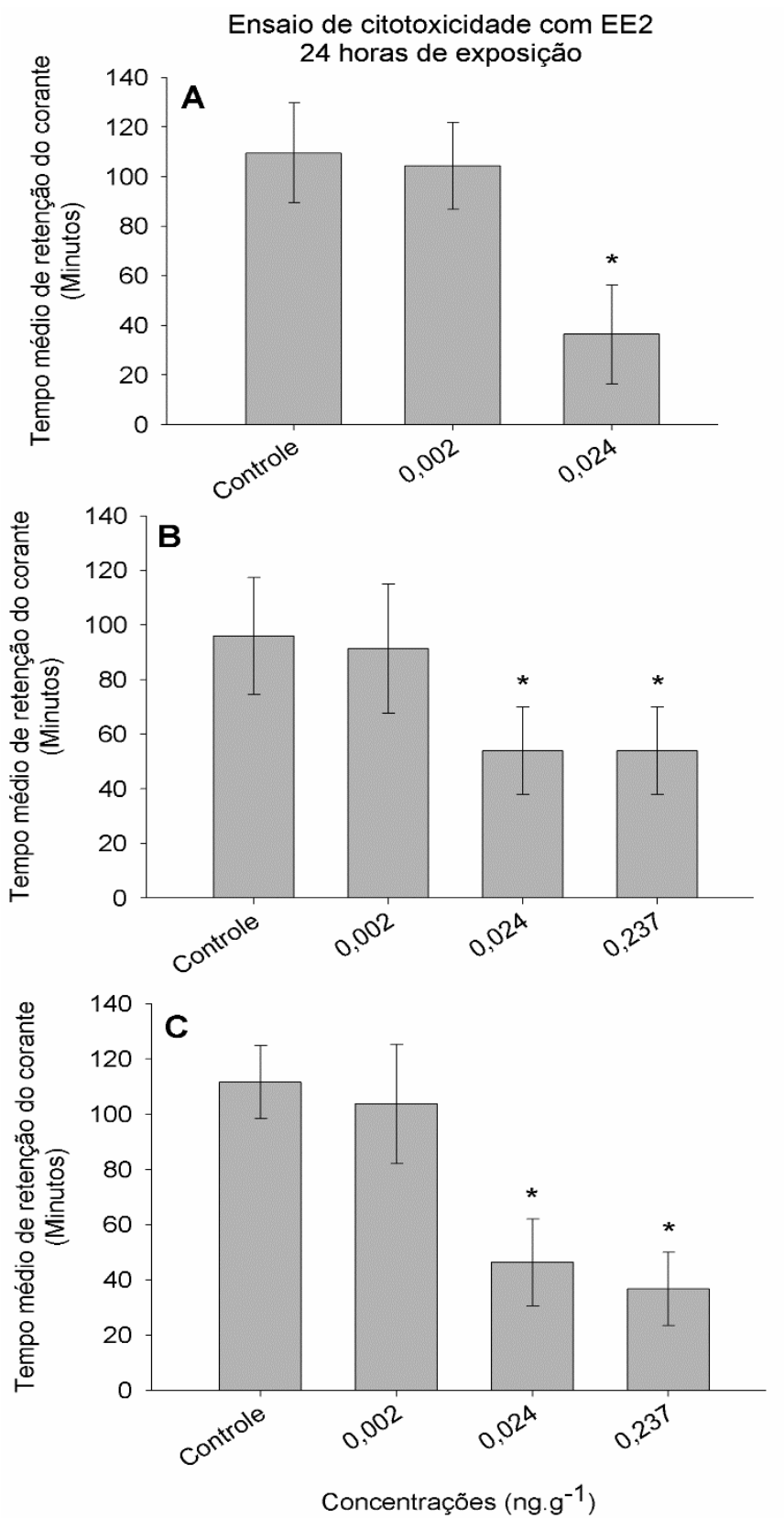

FIGURA 39 - Toxicidade do EE2 em hemócitos do molusco bivalve Mytella charruana após 24 horas de exposição ao sedimento marcado $\left(n g \cdot \mathrm{g}^{-1}\right) \cdot \mathrm{A}=$ Ensaio $1 ; \mathrm{B}=$ Ensaio $2 ; \mathrm{C}=$ Ensaio 3. *Diferença significativa em relação ao controle (ANOVA $-p \leq 0,05$ ). 


\subsubsection{Análise de atividades enzimáticas}

Para avaliação de respostas bioquímicas foram utilizados tecidos (brânquias e glândulas digestivas) de $M$. charruana expostos por 24 horas às amostras de sedimentos marcados com TCS, IBU e EE2. Os resultados da análise de atividades enzimáticas de M. charruana expostos ao TCS estão apresentados nas Figs. 40 e 41.
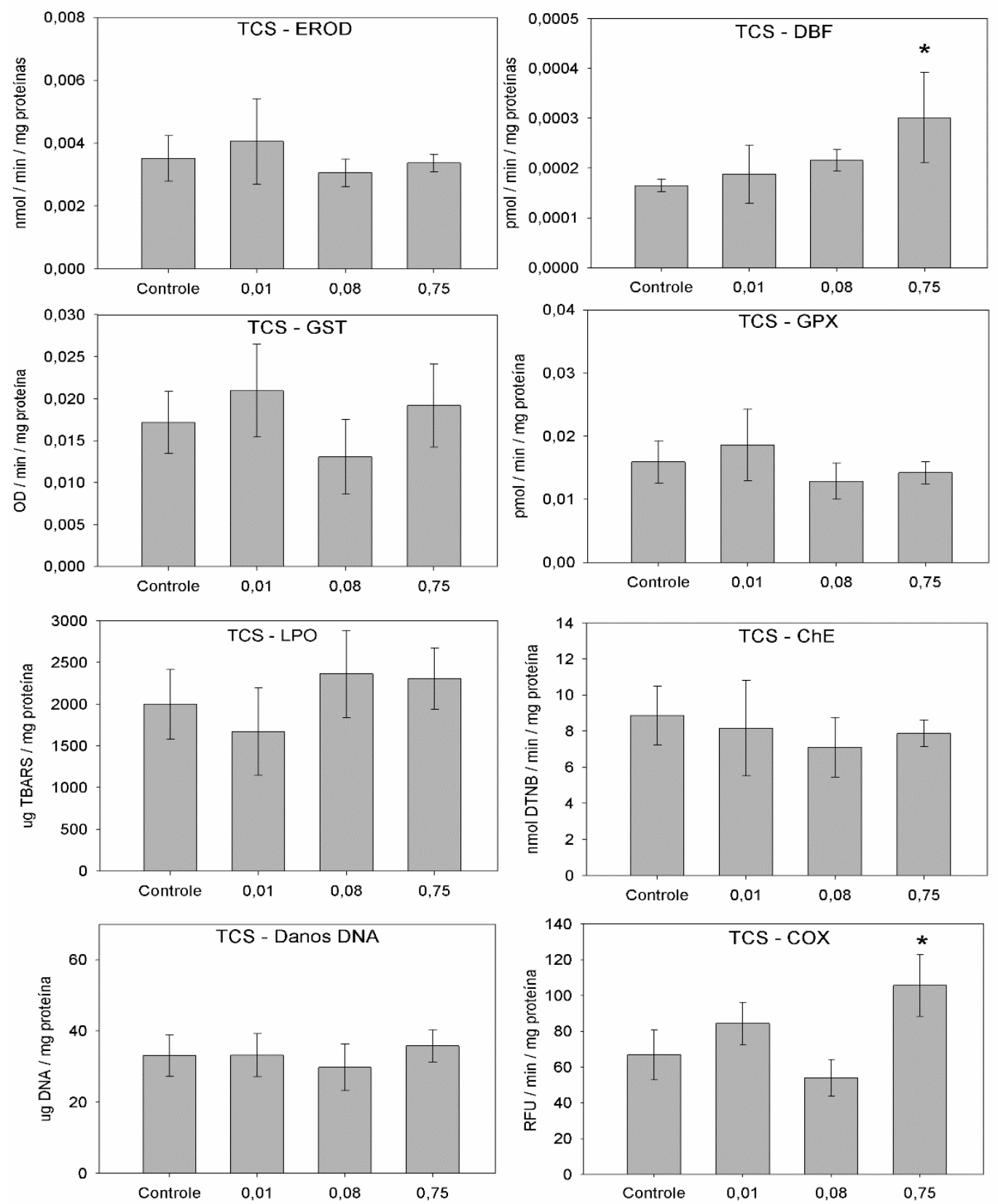

Concentrações (ng. $\mathrm{g}^{-1}$ )

Concentrações $\left(\mathrm{ng} \cdot \mathrm{g}^{-1}\right)$

FIGURA 40 - Média e desvio padrão da EROD, DBF, GST, GPX, LPO, ChE, Danos em DNA e COX de brânquias de M. charruana após 24h de exposição a 
sedimentos marcados com TCS. *Diferença significativa em relação ao controle (ANOVA $-p \leq 0,05)$.
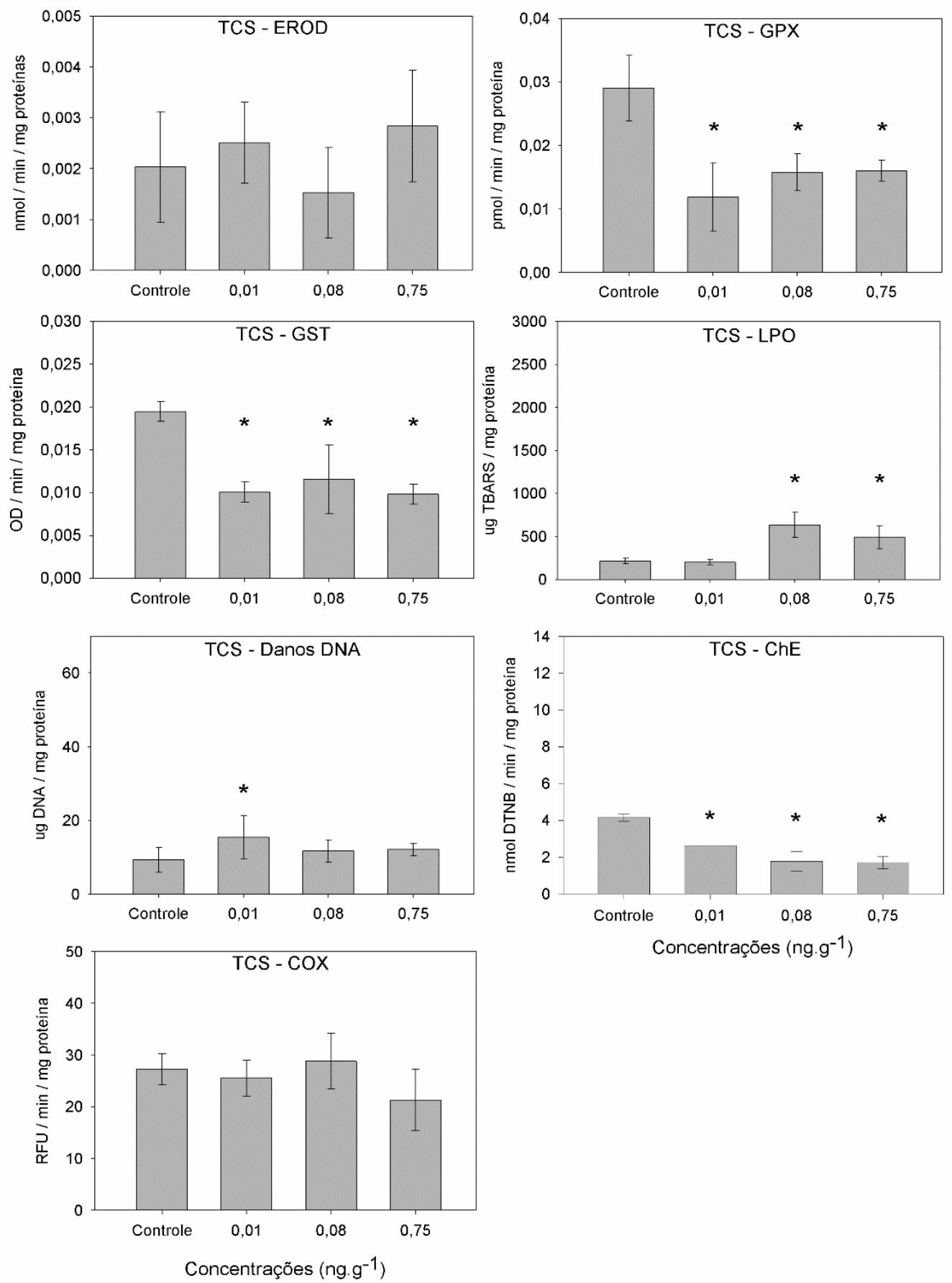

FIGURA 41 - Média e desvio padrão da EROD, GST, GPX, LPO, ChE, Danos em DNA e COX de glândulas digestivas de $M$. charruana após $24 \mathrm{~h}$ de exposição a sedimentos marcados com TCS. *Diferença significativa em relação ao controle (ANOVA $-p \leq 0,05)$. 
A análise dos tecidos dos organismos expostos por $24 \mathrm{~h}$ a sedimentos contaminados com TCS evidenciou alterações significativas nas atividades das enzimas de biotransformação de fase I e II (EROD, DBF e GST) e no sistema antioxidante (GPX), além de efeitos (LPO, DNA, ChE).

O TCS ativou a fase I do metabolismo de detoxificação, onde foi observado aumento da atividade da DBF quando analisado as brânquias de organismos expostos a concentração de $0,75 \mathrm{ng} \cdot \mathrm{g}^{-1}$. Não foi possível mensurar a atividade da DBF na glândula digestiva dos organismos expostos. Embora não tenha sido possível observar alterações no metabolismo de fase I, a glândula digestiva foi o tecido mais responsivo para 0 triclosan após $24 \mathrm{~h}$ de exposição. O triclosan causou diminuição da atividade das enzimas GST e GPX em todas as concentrações analisadas $\left(0,01-0,08-0,75 \mathrm{ng} \cdot \mathrm{g}^{-1}\right)$ quando analisado as glândulas digestivas. Os organismos expostos às concentrações de 0,08 e $0,75 \mathrm{ng} \cdot \mathrm{g}^{-1}$ apresentaram aumento significativo da LPO em relação ao controle, enquanto danos em DNA foram detectados apenas na concentração mais baixa $\left(0,01 \mathrm{ng} \cdot \mathrm{g}^{-1}\right)$. Além disso, foi observada diminuição significativa da atividade da ChE nas glândulas digestivas dos organismos expostos ao triclosan em todas as concentrações analisadas.

O ibuprofeno não ativou as enzimas de fase I do metabolismo de detoxificação, uma vez que não foram observadas diferenças significativas nas atividades relacionadas a EROD e DBF, tanto nas brânquias como nas glândulas digestivas. Embora não tenha sido observado diferença significativa, foi possível observar uma tendência de aumento da DBF quando analisado as glândulas digestivas dos organismos. A análise das brânquias dos mexilhões expostos ao IBU demonstrou diminuição na atividade do metabolismo de conjugação, com redução significativa da GST na concentração de 0,02 ng. $\mathrm{g}^{-1}$. Por outro lado, houve aumento significativo na atividade do sistema antioxidante, com diferenças significativas da GPX nas concentrações de 0,15 e 1,51 ng.g-1. Além disso, foi observada inibição significativa da atividade da ChE na concentração de 0,02 $\mathrm{ng} \cdot \mathrm{g}^{-1}$. As análises realizadas nas glândulas digestivas dos organismos expostos apresentaram resultados semelhantes ao do controle, exceto para a LPO, que apresentou aumento na concentração de $0,15 \mathrm{ng} \cdot \mathrm{g}^{-1}$. Os resultados da análise de atividades enzimáticas em brânquias e glândulas digestivas de $M$. charruana expostos a 
sedimentos marcados com IBU estão apresentados nas Figuras 42 e 43, respectivamente.
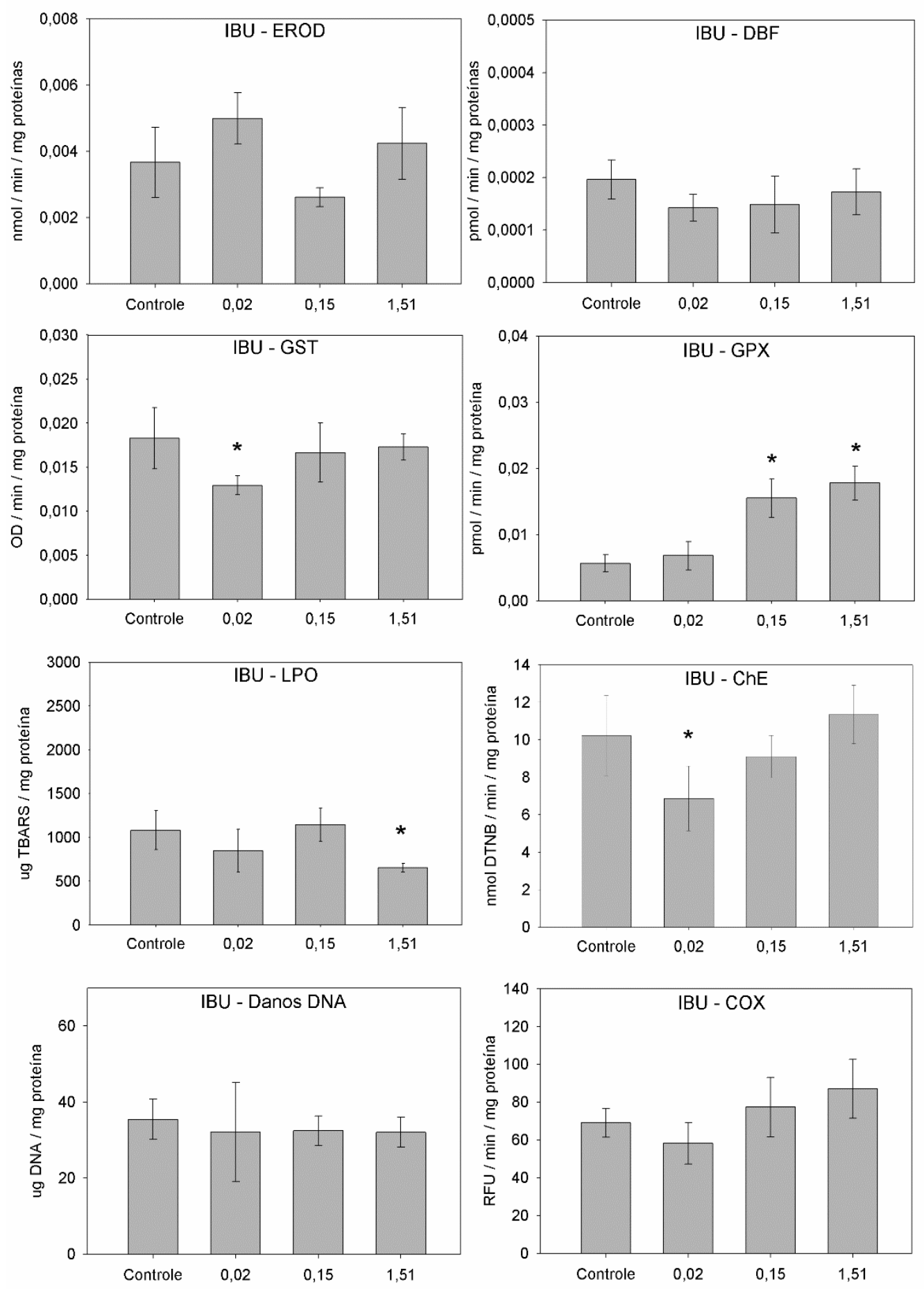

Concentrações (ng. $\mathrm{g}^{-1}$ )

Concentrações (ng.g-1)

FIGURA 42 - Média e desvio padrão da EROD, DBF, GST, GPX, LPO, ChE, Danos em DNA e COX de brânquias de $M$. charruana após 24h de exposição a 
sedimentos marcados com IBU. *Diferença significativa em relação ao controle (ANOVA $-p \leq 0,05)$.
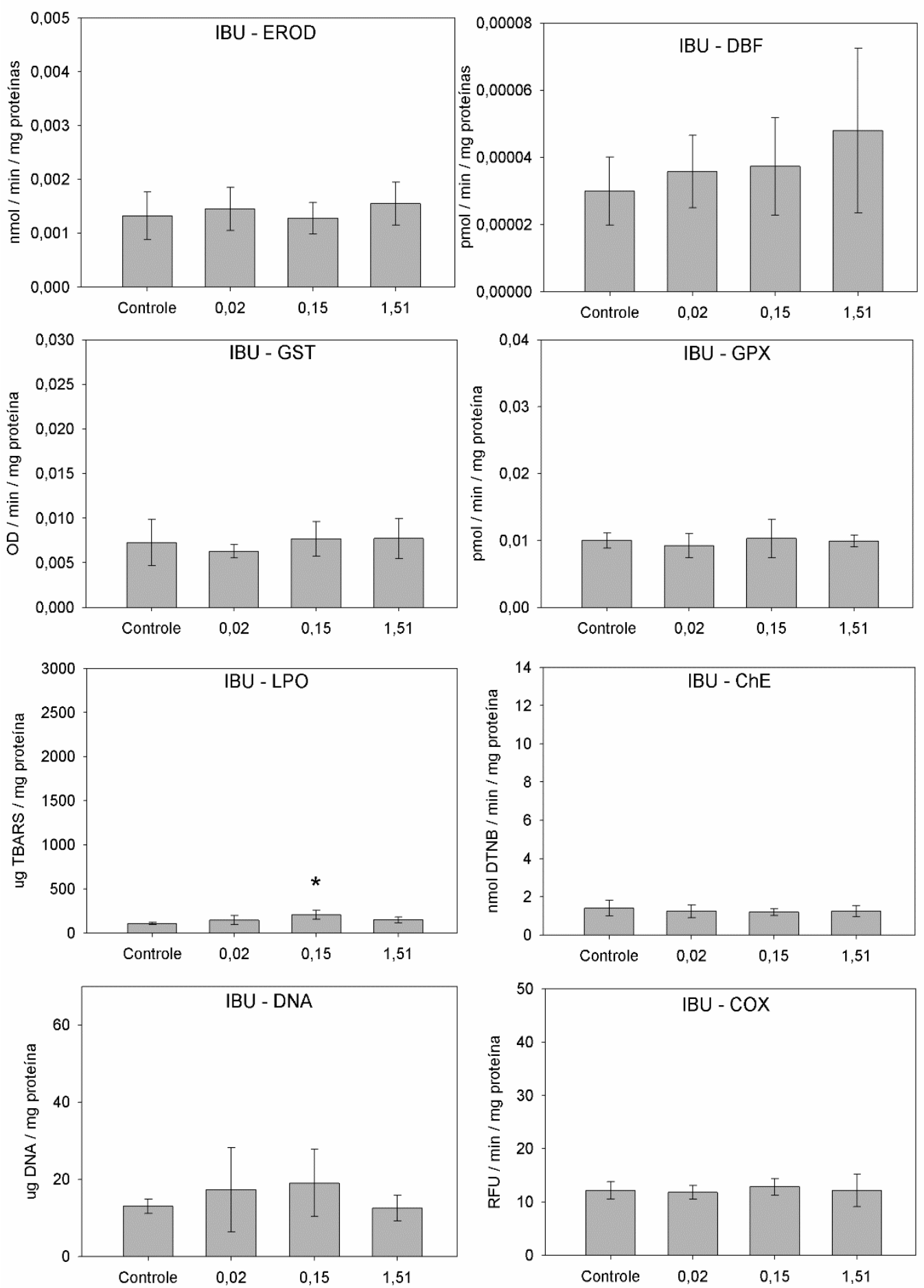

Concentrações $\left(n g \cdot g^{-1}\right)$

Concentrações (ng.g-1)

FIGURA 43 - Média e desvio padrão da EROD, DBF, GST, GPX, LPO, ChE, Danos em DNA e COX de glândulas digestivas de $M$. charruana após $24 \mathrm{~h}$ de exposição 
a sedimentos marcados com IBU. *Diferença significativa em relação ao controle (ANOVA - $p \leq 0,05$ ).

O EE2 ativou o metabolismo de fase I dos organismos expostos, evidenciado pelo aumento da DBF nas glândulas digestivas nas concentrações de 0,024 e 0,237 ng.g-1 $\cdot A$ GST, GPX e a ChE não foram responsivas para exposição ao EE2, tanto no tecido branquial quando nas glândulas digestivas. Entretanto, o efeito oxidativo foi evidenciado pelo aumento nos níveis de danos em DNA na concentração de $0,237 \mathrm{ng} \cdot \mathrm{g}^{-1}$ quando analisadas as brânquias de $M$. charruana. Não foram observadas alterações significativas das enzimas COX. Os resultados da análise de atividades enzimáticas de $M$. charruana expostos ao EE2 estão apresentados nas Figuras 44 e 45. 

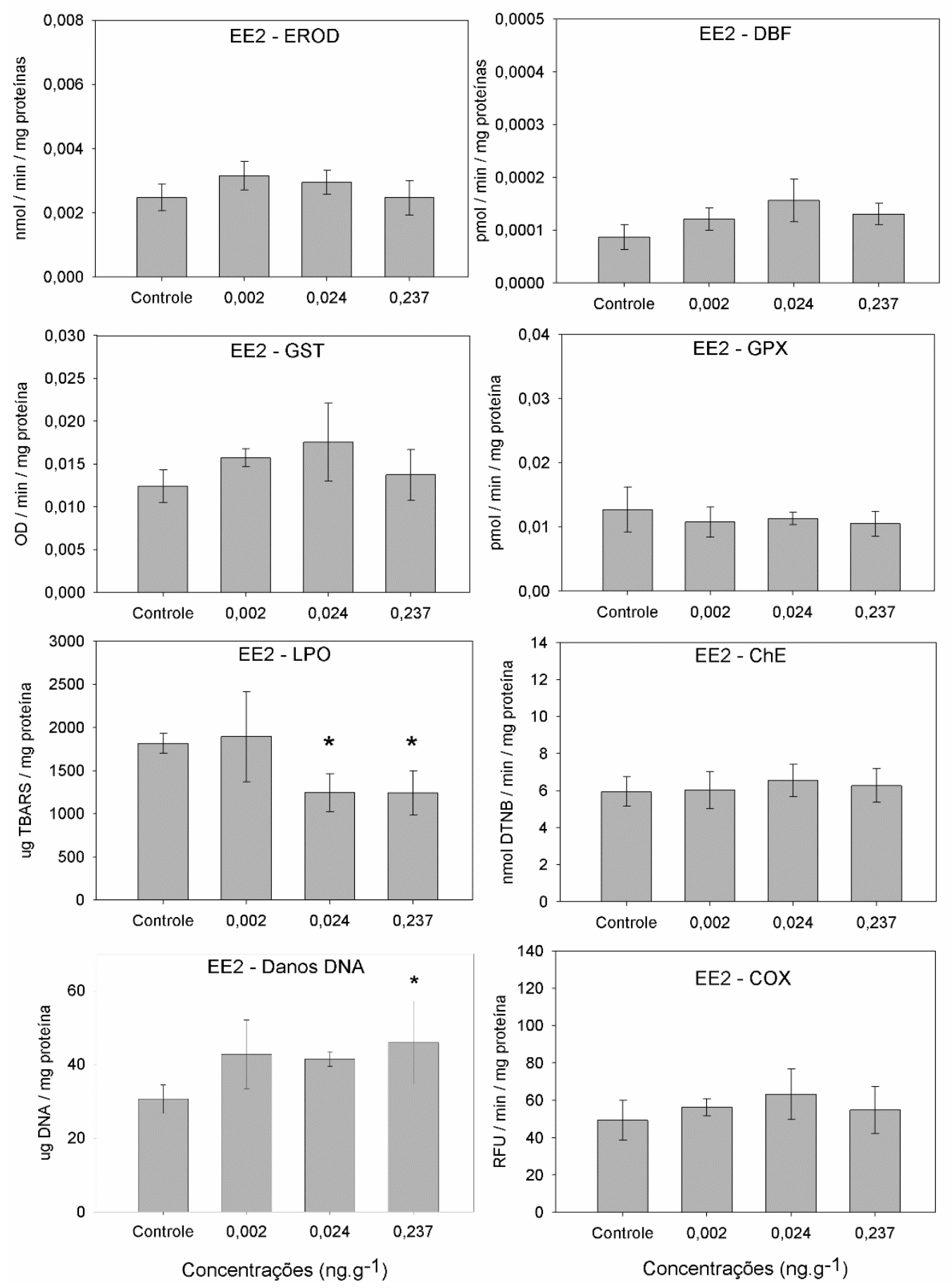

FIGURA 44 - Média e desvio padrão da EROD, DBF, GST, GPX, LPO, ChE, Danos em DNA e COX de brânquias de $M$. charruana após 24h de exposição a sedimentos marcados com EE2. *Diferença significativa em relação ao controle (ANOVA $-p \leq 0,05)$. 

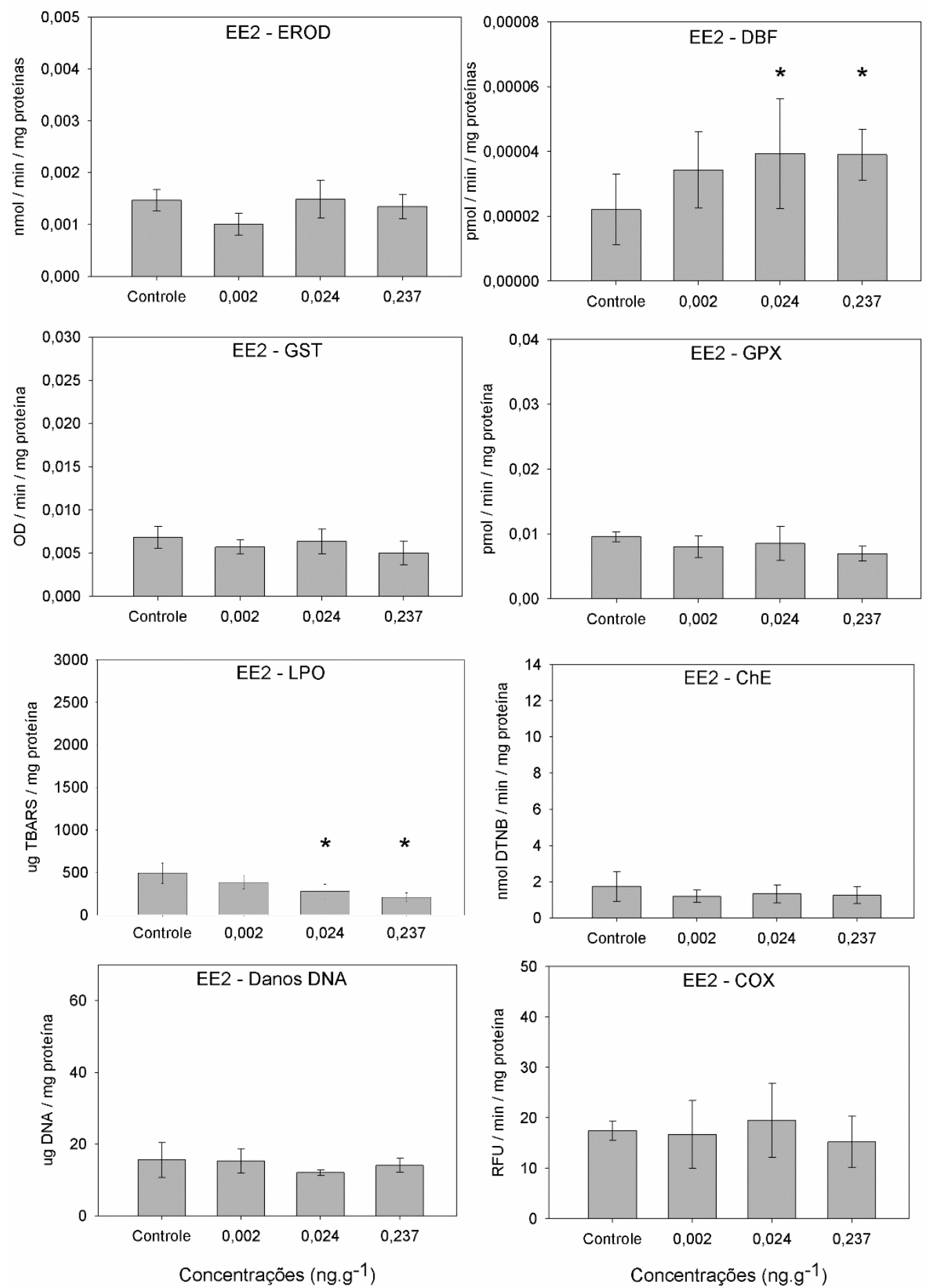

FIGURA 45 - Média e desvio padrão da EROD, DBF, GST, GPX, LPO, ChE, Danos em DNA e COX de glândulas digestivas de $M$. charruana após 24h de exposição a sedimentos marcados com EE2. *Diferença significativa em relação ao controle (ANOVA $-p \leq 0,05$ ). 


\subsubsection{Avaliação de risco ambiental}

O risco ambiental de sedimentos contaminados com FPCP para invertebrados marinhos foi determinado baseando-se em quocientes de risco $(Q R)$, calculados a partir da maior concentração ambiental mensurada de cada composto (MEC) encontrada na baía de Santos, e das concentrações onde não são previstos efeitos (PNECs). No caso do EE2, que não foi detectado nas amostras ambientais coletadas, o valor do QR foi obtido por meio do emprego das concentrações ambientais de ambientes estuarinos no Brasil $\left(0,11 \mathrm{ng} \cdot \mathrm{g}^{-1}\right)$ obtidas no estudo realizado por Froehner et al. (2012).

Os valores de QR para o TCS, IBU e EE2 estão apresentados na Tabela 11. Vale ressaltar que, para o cálculo das PNECs, foi utilizada a relação entre as menores concentrações de efeito não observado (CENO) obtidas nos ensaios de toxicidade crônica e o fator de avaliação 10. De acordo com resultados obtidos, e a classificação proposta pela EMEA (2006), os três compostos analisados (TCS, IBU e EE2) e encontrados nos sedimentos da Baia de Santos apresentaram alto risco para os invertebrados marinhos bentônicos testados, mesmo considerando somente os ensaios a nível de indivíduo (embriolarval). 
TABELA 11 - Concentrações onde não são previstos efeitos (PNECs) obtidas a partir dos ensaios com ISA (Interface sedimentoágua), ELU (Elutriato) e SI (Sedimento integral), e os quocientes de risco (QR) dos compostos detectados no entorno do ESS.

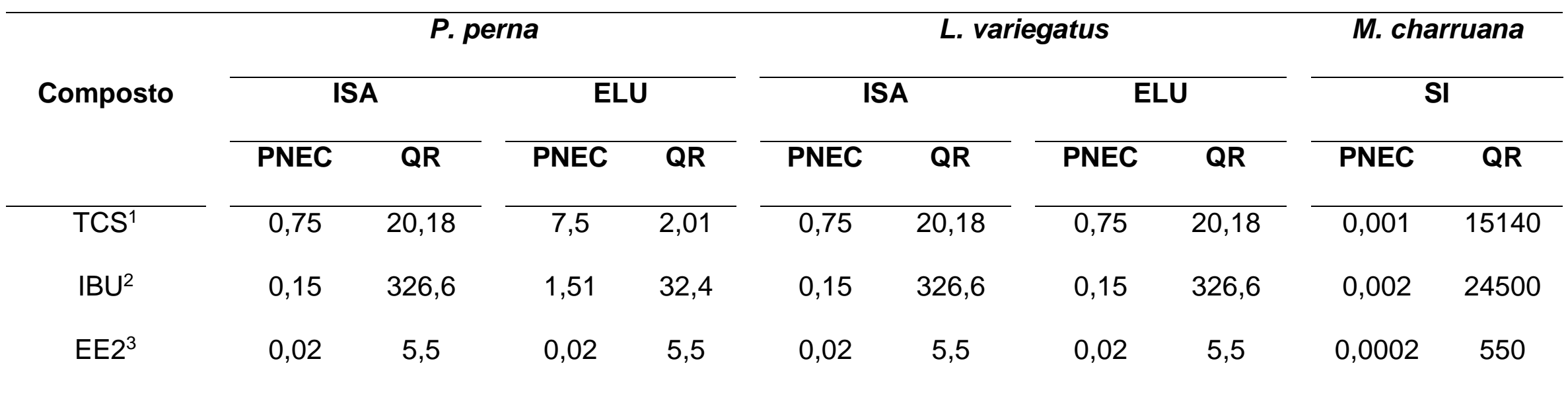

${ }^{1} \mathrm{MEC}=15,14 \mathrm{ng} \cdot \mathrm{g}^{-1} ;{ }^{2} \mathrm{MEC}=49,0 \mathrm{ng} \cdot \mathrm{g}^{-1} ;{ }^{3} \mathrm{MEC}=0,11 \mathrm{ng} \cdot \mathrm{g}^{-1}$ (Froehner, et al. 2012). 


\section{DISCUSSÃO}

A ocorrência de FPCP no meio ambiente tem sido relatada desde a década de 1990, e com maior intensidade a partir do século XXI, principalmente devido ao avanço da química analítica e desenvolvimento de métodos mais sensíveis capazes de detectar estes compostos, uma vez que ocorrem em baixas concentrações no ambiente. Os estudos demonstram a presença de várias classes de FPCP, como antibióticos, bactericidas, hormônios, anestésicos, antilipêmicos, antidepressivos, anti-inflamatórios, dentre outros, em diversas matrizes, como esgotos domésticos, efluentes hospitalares e de indústrias farmacêuticas, águas superficiais e sedimentos.

Os contaminantes, após atingirem o ambiente, tendem a acumular-se nos sedimentos, que passam a funcionar não só como repositório, mas como fonte de contaminação para organismos bentônicos, por exposição direta, e também para os pelágicos, por meio da ressuspensão destes provocada por atividades biológicas, bioturbação, tempestades, dragagens; hábito alimentar, ou ainda, pela troca que existe entre a água intersticial e a água sobrejacente aos sedimentos. Desta forma, o conhecimento do destino e concentrações ambientais dos FPCP em sedimentos tornase essencial para determinação da exposição à biota e do risco ambiental associado aos FPCP.

Os altos valores dos coeficientes de partição octanol-água (Kow) do TCS, IBU e EE2 indicam alta tendência de adsorção destes compostos à matéria orgânica e acumulação na biota e em sedimentos. Além disso, estudos demonstram que estes compostos são altamente resistentes a degradação no ambiente, com tempos de meia vida de 40, 19 e 108 dias, respectivamente (Conkle et al., 2012; Zuo et al., 2013; Huang et al., 2015). De acordo com Barel-Cohen et al. (2006), embora concentrações de EE2, por exemplo, sejam reduzidas à metade após $25 \mathrm{~km}$ da fonte do lançamento de esgoto, o composto ainda pode ser detectado a mais de $100 \mathrm{~km}$ de distância da fonte em rios.

A Tabela 12 apresenta um levantamento das concentrações ambientais em sedimentos de cada um dos fármacos analisados neste estudo. 
TABELA 12 - Concentrações ambientais do TCS, EE2 e IBU em sedimentos reportadas na literatura.

\begin{tabular}{|c|c|c|c|c|}
\hline Composto & Sedimento & País & Concentração $\left(\mathbf{n g} \cdot \mathbf{g}^{-1}\right)$ & Referência \\
\hline \multirow{18}{*}{ TCS } & Lago & Suíça & 53 & Singer, et al. (2002) \\
\hline & Lago & EUA & 37 & Blair, et al. (2013) \\
\hline & Rios & EUA & 50 & Anger, et al. (2013) \\
\hline & Rios & China & $345-1329$ & Zhao, et al. (2010) \\
\hline & Rios & EUA & $0,4-85$ & Venkatesan, et al. (2012) \\
\hline & Rios & Espanha & $4,4-35,7$ & Morales, et al. (2005) \\
\hline & Rios & China & 1329 & Zhao, et al. (2013) \\
\hline & Rios & EUA & 0,38 & Gautam, et al. (2014) \\
\hline & Rios & Espanha & 6 & Carmona, et al. (2014) \\
\hline & Rios & Brasil & 176 & Sousa, et al. (2015) \\
\hline & Estuário & EUA & $51-400$ & Cantwell, et al. (2010) \\
\hline & Estuário & Espanha & $0,3-9,6$ & Pintado-Herrera, et al. (2014) \\
\hline & Estuário & EUA & $2,0-37$ & Wilson, et al. (2009) \\
\hline & Estuário & EUA & $0,17-6,0$ & Kerrigan, et al. (2015) \\
\hline & Marinho & Espanha & $12,0-43,0$ & Pintado-Herrera, et al. (2013) \\
\hline & Marinho & Espanha & $0,27-130,7$ & Agüera, et al. (2003) \\
\hline & Marinho & Alemanha & $<0,4-13$ & Xie, et al. (2008) \\
\hline & Marinho & Brasil & 15,14 & Presente estudo \\
\hline \multirow{10}{*}{ EE2 } & Lago & Itália & $<2,0-41$ & Pojana, et al. (2007) \\
\hline & Lago & China & 2,18 & Zhang, et al. (2009) \\
\hline & Lago & China & $1,93-2,48$ & Zhang, et al. (2011) \\
\hline & Rios & Espanha & $4,16-22,8$ & Alda, et al. (2002) \\
\hline & Rios & Alemanha & 0,9 & Ternes, et al. (2002) \\
\hline & Rios & China & $0,81-9,26$ & Lei, et al. (2009) \\
\hline & Rios & China & 5,1 & Zhou, et al. (2011) \\
\hline & Estuário & Brasil & $0,11-129,78$ & Froehner, et al. (2012) \\
\hline & Estuário & Brasil & 70,28 & Pimentel, et al. (2016) \\
\hline & Marinho & Austrália & $<0,05-0,5$ & Braga, et al. (2005) \\
\hline
\end{tabular}

(Continua) 
TABELA 12 - Concentrações ambientais do TCS, EE2 e IBU em sedimentos reportadas na literatura (continuação).

\begin{tabular}{rlccr}
\hline Composto & Sedimento & País & Concentração $\left(\mathbf{n g} \cdot \mathbf{g}^{-1} \mathbf{)}\right.$ & \multicolumn{1}{c}{ Referência } \\
\hline \multirow{2}{*}{ Rios } & China & 12,8 & Duan, et al. (2013) \\
& Rios & Espanha & 30 & Carmona, et al. (2014) \\
& Rios & África do Sul & $4,76-11,2$ & Agunbiade \& Moodley (2016) \\
& Rios & África do Sul & 659 & Matongo, et al. (2015) \\
\cline { 2 - 3 } IBU & Marinho & Dinamarca & $0,21-0,26$ & Huber, et al. (2016) \\
& Marinho & Islândia & 2,57 & Huber, et al. (2016) \\
& Marinho & Groelândia & 0,18 & Huber, et al. (2016) \\
& Marinho & Espanha & 100 & Pintado-Herrera, et al. (2013) \\
& Marinho & Brasil & $0,77-18,8$ & Beretta, et al. (2014) \\
& Marinho & Brasil & 49,0 & Presente estudo \\
\hline
\end{tabular}

A análise química realizada nas amostras de sedimentos coletadas no entorno do ESS demonstrou a ocorrência de TCS $\left(15,14 \mathrm{ng} \cdot \mathrm{g}^{-1}\right)$ e IBU $\left(49,0 \mathrm{ng} \cdot \mathrm{g}^{-1}\right)$ na mesma faixa de concentrações reportadas na literatura. A presença de TCS em sedimentos marinhos foi reportada em concentrações na faixa de 43 a 130,7 ng.g ${ }^{-1}$ na Baía de Cádiz, Espanha (Agüera, et al. 2003; Pintado-Herrera, et al. 2013), e de 0,3 a 9,6 ng.g $\mathrm{g}^{-1}$ em sedimentos estuarinos de Guadalete River, sudeste da Espanha (Pintado-Herrera, et al. 2014). Ainda no que se refere a sedimentos estuarinos, TCS foi detectado em concentrações de 2,0 a 37 ng.g ${ }^{-1}$ no sistema estuarino de Hudson River, nos Estados Unidos (Wilson, et al. 2009). As maiores concentrações ambientais de TCS foram reportadas em sedimentos dulcícolas de Pearl River, no sul da China, em concentrações na faixa de 345 a 1326 $\mathrm{ng}^{\mathrm{g}} \mathrm{g}^{-1}$ (Zhao, et al. 2010). Embora o TCS já tenha sido reportado em águas superficiais no Brasil (Montagner et al., 2014), este é o primeiro estudo que aponta sua ocorrência em sedimentos no país.

Os dados de IBU foram similares ao reportado em estudo realizado por Beretta e colaboradores (2014), que encontraram concentrações de 0,77 a $18,8 \mathrm{ng} \cdot \mathrm{g}^{-1} \mathrm{em}$ sedimentos da Baia de Todos os Santos, na Bahia. As maiores concentrações ambientais detectadas de IBU foram reportadas na Baia de Cádiz, Espanha (100 ng. $\left.\mathrm{g}^{-1}\right)$ e na África do Sul (659 ng.g-1) (Pintado-Herrera, et al. 2013; Matongo, et al. 2015). Recentemente, 
Pereira e colaboradores (2016) realizaram o primeiro estudo para detecção da presença de fármacos na região da baia de Santos. Em amostras de água coletadas próximo ao lançamento de esgoto pelo emissário submarino municipal, diferentes classes de fármacos foram detectadas, no qual o ibuprofeno apresentou as concentrações mais elevadas, variando de 326,1 até 2094,4 ng. L-1.

Embora o EE2 seja muito utilizado na medicina humana e diversos trabalhos tenham reportado sua ocorrência em sedimentos (Tab. 11), no presente estudo não foi possível determinar concentrações de EE2 nas amostras coletadas no entorno do ESS. Porém, vale ressaltar que o limite de detecção do método utilizado no presente estudo foi relativamente alto $\left(33,3 \mathrm{ng}^{-1} \mathrm{~g}^{-1}\right)$ para este composto, uma vez que Froehner e colaboradores (2012) quantificaram EE2 em sedimentos de manguezais em concentrações de $0,11 \mathrm{ng} \cdot \mathrm{g}^{-1}$. A literatura indica uma grande variedade de metodologias analíticas para detecção de FPCP em águas superficiais e sedimentos, entretanto, estudos recentes têm focado no desenvolvimento e aplicação de métodos genéricos que permitem a análise simultânea de compostos de diferentes classes (Gros et al., 2009).

No presente estudo, a determinação de FPCP em sedimentos por meio da análise de multi-compostos não se mostrou adequada para detectar o EE2. O uso de um método específico para este composto poderia diminuir o limite de detecção, possibilitando evidenciar sua ocorrência em concentrações mais baixas $\left(<33,3 \mathrm{ng} \cdot \mathrm{g}^{-1}\right)$. Nesse sentido, vale ressaltar a necessidade de estudos voltados ao desenvolvimento e validação de metodologias analíticas específicas para determinação de FPCP, especialmente para classe dos hormônios.

De acordo com Comissão Europeia (EC, 2010) e a USEPA (2007), os intervalos aceitáveis de recuperação para análise geralmente estão entre 70 e 110\%, porém, dependendo da complexidade analítica e da amostra, como é o caso de sedimentos, este valor pode ser de 50 a $120 \%$, com coeficiente de variação de $\pm 20 \%$. No que diz respeito a recuperação de resíduos em concentrações abaixo de $10 \mathrm{ng}^{-g^{-1}}$, pode-se considerar aceitável coeficientes de variação de até $30 \%$. Além disso, os valores de exatidão obtidos 
nas diferentes concentrações analisadas, evidenciaram consistência do método empregado.

Vale ressaltar que a granulometria e baixa concentração de matéria orgânica do sedimento controle pode interferir diretamente no processo de marcação dos compostos (spiking) e, consequentemente, no padrão de recuperação do método analítico. Frações granulométricas menores apresentam maior afinidade com os FPCP devido sua maior área de superfície de contato (área/volume), possibilitando maior número de sítios de ligações entre os FPCP e as partículas de sedimento, facilitando os processos de sorção, complexação e coprecipitação, que ocorrem entre os contaminantes e sedimento (Moore, et al 1989). O uso de sedimentos com frações granulométricas menores e com maiores concentrações de matéria orgânica, podem diminuir a perda dos FPCP durante o processo de marcação e, inclusive, favorecer a retenção dos compostos no sedimento, diminuindo a solubilização na água nos sistemas de exposição de interface sedimentoágua e elutriato. Nesse sentido, existe a necessidade de estudos com a marcação de FPCP em diferentes tipos de sedimentos com o intuito de avaliar a interferência da matriz no processo de marcação.

Os FPCP, diferentemente dos poluentes convencionais, são compostos biologicamente ativos, desenvolvidos para interagir com vias fisiológicas específicas em organismos alvo. Desta forma, fazem parte de uma classe de contaminantes emergentes capazes de causar efeitos em funções específicas de animais (ex: desenvolvimento, crescimento, reprodução), mesmo que em baixas concentrações, especialmente pelo fato destes compostos serem introduzidos de forma contínua no ambiente aquático (Fabbri \& Franzellitti, 2015).

Orvos et al. (2002) demonstraram a toxicidade do TCS para algas, microcrustáceos e peixes, em concentrações que variaram de 1,4 a $390 \mu \mathrm{g} \cdot \mathrm{L}^{-1}$, enquanto Ciniglia et al. (2005) encontraram efeitos geno e citotóxicos à $250 \mu \mathrm{g} \cdot \mathrm{L}^{-1}$. Cortez e colaboradores (2012) observaram efeitos biológicos (desenvolvimento embriolarval e citotoxicidade) do TCS em mexilhões marinhos em concentrações ambientalmente relevantes, em ordem de magnitude de ng. $\mathrm{L}^{-1}$. Além disso, por meio do uso de bactérias 
(Vibrio fischeri), Farré et al. (2008) demonstraram que o TCS e o metil-triclosan (subproduto da degradação biológica do TCS (Lindström et al. 2002)) são dois dos principais poluentes orgânicos que contribuem para toxicidade de efluentes domésticos. Aguirre-Martínez e colaboradores (2013a) reportaram danos em DNA e efeitos citotóxicos do ibuprofeno sobre caranguejos Carcinus maenas em concentrações de 5 e $10 \mu \mathrm{g} \cdot \mathrm{L}^{-1}$, respectivamente, enquanto Scholz \& Gutzeit (2000) detectaram diminuição da produção de ovos de peixes após exposição ao EE2 em concentrações de $10 \mathrm{ng} \cdot \mathrm{L}^{-1}$.

Neste sentido, diversos estudos reportam efeitos em organismos aquáticos (conforme reportado no parágrafo anterior), especialmente planctônicos e pelágicos, entretanto, poucos estudos demonstram efeitos de sedimentos contaminados com FPCP, especialmente sobre organismos bentônicos de regiões tropicais.

No que diz respeito a efeitos de sedimentos contaminados com FPCP, Perron e colaboradores (2012), avaliaram a toxicidade aguda de sedimentos contaminados com TCS sobre anfípodes estuarinos Ampelisca abdita e misidáceos Americamysis bahia, com concentrações de efeito, após 7 dias de exposição ao sedimento integral, de $303 \mathrm{e}$ $257 \mu \mathrm{g} \cdot \mathrm{g}^{-1}$, respectivamente. Pusceddu (2009) avaliou a toxicidade aguda e crônica de sedimentos contaminados com TCS para dois invertebrados de água doce, com efeitos em concentrações de (CE50) 45,26 $\mu \mathrm{g} \mathrm{g}^{-1}$ para Chironomus xanthus e CENO de 5,78 $\mu \mathrm{g} \cdot \mathrm{g}^{-1}$ para Ceriodaphnia dubia, respectivamente.

Maranho et al. (2015a) realizaram uma bateria de ensaios para avaliação da toxicidade de fármacos em sedimentos com organismos marinhos tradicionalmente utilizados em avaliações ambientais. Dentre os compostos utilizados neste mesmo estudo, o IBU e o EE2 causaram inibição da bioluminescência de bactérias $V$. fisheri (Cl50) em concentrações de 100,6 e 39,4 ng.g ${ }^{-1}$, e inibição do crescimento de algas ( $T$. chuii) em concentrações de 5,0 e 1,0 ng.g ${ }^{-1}$, respectivamente. Nos ensaios realizados para avaliação do desenvolvimento embriolarval do ouriço-do-mar Paracentrotus lividus, foi observada resposta ainda mais sensível, com concentrações de efeito de $0,01 \mathrm{ng} \cdot \mathrm{g}^{-1}$ para EE2. Além disso, Maranho et al. (2014) reportaram efeito oxidativo (LPO) e mortalidade de poliquetas da espécie Hediste diversicolor após a exposição a sedimentos 
contaminados com EE2 em concentrações de 0,01 e 10,0 ng.g ${ }^{-1}$, respectivamente. Maranho e colaboradores (2015b) observaram efeito agudo em poliquetas $\mathrm{H}$. diversicolor após exposição ao EE2 nas concentrações de 10 e 100 ng.g ${ }^{-1}$.

O estágio embriolarval de organismos aquáticos tem sido amplamente utilizado para avaliação da qualidade de ecossistemas aquáticos (água e sedimentos) devido à sua baixa tolerância a compostos tóxicos. No presente estudo, TCS, IBU e EE2 apresentaram efeitos no desenvolvimento embriolarval de mexilhões Perna perna e ouriços-do-mar Lytechinus variegatus na mesma faixa de concentrações reportadas na literatura, com efeitos em 75, 15 e 2,37 $\mathrm{ng}^{-g^{-1}}$, respectivamente. Vale ressaltar que os compostos analisados apresentaram efeitos crônicos em concentrações ambientalmente relevantes.

No que se refere aos ensaios com Perna perna, foi observada diferença na sensibilidade dos organismos em relação aos sistemas de exposição (ISA e ELU) ao TCS e IBU, no qual a interface sedimento-água apresentou efeito em concentrações mais baixas que o elutriato. Já o EE2 não apresentou diferença nas concentrações de efeito entre a exposição à ISA e ELU.

Essa diferença de sensibilidade nos ensaios com ISA e ELU para triclosan e ibuprofeno, pode estar relacionada à biodisponibilidade dos compostos nos sedimentos, no elutriato e na coluna d'água, assim como a constante de equilíbrio e dissociação ácida dos compostos (pKa).

De acordo com a teoria de Brönsted-Lowry, a força de um ácido depende da sua constante de equilíbrio ácido-base em água, ou seja, do seu valor de pKa. Quanto maior o valor de pKa de uma substância, mais fraco é o ácido. Em busca de neutralização (equilíbrio), ácidos fracos tendem a se dissociar com mais facilidade do que ácidos fortes em meios alcalinos. Desta forma, a dissociação de um ácido fraco ocorre de forma mais fácil em solução aquosa básica, como é o caso da água do mar.

No processo de ELU, o sedimento permanece em agitação em água marinha por 30 minutos e, após esse período, o sobrenadante é retirado para exposição dos 
organismos. Já no ISA, os organismos são expostos somente após 24 h de interação entre a água e o sedimento, e o sistema permanece durante todo período de exposição dos organismos (48h). Desta forma, no sistema de ISA o sedimento permanece por mais tempo em interação com a água, possibilitando assim maior dissolução dos compostos com baixo pKa em relação ao sistema de ELU. Neste sentido, os efeitos tóxicos do TCS $(\mathrm{pKa}=7,9)$ e IBU ( $\mathrm{pKa}=4,91)$, que foram maiores na exposição a ISA, podem estar relacionados aos valores de pKa destes compostos, que são mais baixos que o EE2 (pKa $=10,33)$ e, consequentemente, apresentam maior dificuldade de se dissociar na água. Este fato reforça a importância do uso de ensaios para avalição da toxicidade com diferentes organismos-teste e sistemas de exposição.

O EE2 foi o composto que apresentou maior toxicidade em relação ao TCS e IBU nos ensaios para avaliação de efeitos crônicos no desenvolvimento embriolarval de mexilhões e ouriços-do-mar. Os efeitos tóxicos mais severos do EE2 podem estar relacionados a sua capacidade de diminuir a produção de gametas tanto de machos como fêmeas, além de reduzir a qualidade, a fertilidade e a fecundidade de gametas (Jobling et al., 2003; Fenske et al., 2005; Notch et al., 2007; Pojana et al., 2007; Hallgren et al., 2012). Além disso, estudos demonstram que a exposição ao EE2 por apenas 24 horas afeta os genes envolvidos no metabolismo hormonal, no metabolismo da vitamina A, no crescimento celular e na indução de vitelogenina em peixes (Hoffmann et al., 2006). Nesse sentido, o EE2 pode, direta ou indiretamente, reduzir a sobrevivência, o crescimento nos estágios iniciais do ciclo de vida e o sucesso reprodutivo desses invertebrados, assim como causar impacto a nível populacional (Aris et al., 2014).

O sedimento de referência utilizado no processo de marcação (spiking) apresentou boa qualidade ambiental, uma vez que o mesmo foi utilizado nos controles dos ensaios, os quais estiveram dentro dos critérios de aceitabilidade dos métodos. Vale ressaltar que os ensaios de toxicidade apresentaram baixos desvios-padrão para as três espécies testadas, demonstrando a eficácia e reprodutibilidade do processo de homogeneização dos sedimentos por meio do uso do equipamento desenvolvido para realização deste estudo, baseado no sitema jar-rolling. 
Recentemente, estudos têm utilizado a teoria do equilíbrio de partição para estimar concentrações de efeito de FPCPs em água intersticial a partir de concentrações de efeito em sedimentos, assim como estimado efeitos em sedimentos a partir de dados de concentrações de efeito em água (Hernando, et al. 2006; Perron, et al. 2012; Venkatesan, et al. 2012; Nie, et al. 2015).

Esta abordagem utiliza os valores do coeficiente de partição do carbono orgânico no sedimento $\left(K_{o c}{\mathrm{~L} . \mathrm{kg}^{-1}}^{-1}\right)$, do coeficiente de partição octanol-água $\left(\log _{10} K_{o w}=4,76\right.$ para TCS; $\log _{10} K_{o w}=3,97$ para IBU; $\log _{10} K_{o w}=4,2$ para EE2), da concentração de efeito em sedimentos $\left(C_{\text {sed }} \mu \mathrm{g} \cdot \mathrm{g}^{-1}\right)$ e da fração de carbono orgânico $\left(f_{o c} \%=22,1 \%\right)$, para estimar a concentração de efeito na água intersticial $\left(C_{p w}\right)$ por meio da equação 2 (USEPA, 1993):

$$
\text { (2) } C_{p w}=\frac{C_{s e d}}{K_{o c} \times f_{o c}}
$$

De acordo com a USEPA (1993), é amplamente aceito que o Koc pode ser estimado a partir dos valores do Kow. $O$ Koc utilizado para calcular a concentração de efeito na água intersticial foi baseado na regressão do $\log _{10} K_{o c}$ para $\log _{10} K_{o w}$, de acordo com a equação 3:

$$
\text { (3) } \log _{10} K_{o c}=0.00028+0.983 \log _{10} K_{\text {ow }}
$$

Considerando os menores valores de CEO dos ensaios para avaliação da toxicidade crônica de sedimentos contaminados com TCS $\left(75,02 \mathrm{ng}^{-1} \mathrm{~g}^{-1}\right)$, IBU $\left(15,08 \mathrm{ng} \cdot \mathrm{g}^{-}\right.$ $\left.{ }^{1}\right)$ e EE2 (2,37 $\left.\mathrm{ng} \cdot \mathrm{g}^{-1}\right)$, a equação utilizada estimou concentrações de efeito dos FPCP em água intersticial de 73, 17 e $3 \mu \mathrm{g} . \mathrm{L}^{-1}$, respectivamente. Embora esta estimativa deva ser utilizada com cautela, uma vez que não leva em consideração diversos interferentes de matrizes complexas como os sedimentos, os valores obtidos foram similares aos dados de efeito de TCS e IBU reportados na literatura para algas e cladóceros (Orvos et al. 2002; DeLorenzo \& Fleming 2008), peixes (Nassef et al. 2010), anfíbios (Palenske et al. 2010), larvas de insetos (Dussault et al. 2008), copépodos (Breitholtz \& Bengtsson, 2001), bivalves marinhos (Cortez et al. 2012) e caranguejos (Aguirre-Martínez 2013a). 
Entretanto, no que se refere ao EE2, a concentração estimada pela equação foi uma ordem de grandeza acima das concentrações de efeito reportadas na literatura (ng. L-1).

\subsection{Biomarcadores}

Moluscos bivalves, como mexilhões e ostras, têm sido amplamente utilizados em estudos ambientais devido ao seu hábito filtrador e sedentário. Estes organismos podem acumular substâncias químicas, principalmente metais e compostos lipofílicos, através da filtração de água e material particulado contaminado, o que os tornam importantes sentinelas da qualidade ambiental.

Embora os mexilhões sejam relativamente tolerantes a muitos metais e xenobióticos orgânicos, não significa que estes animais não sejam responsivos, pois existem evidências de reações patológicas em diferentes níveis de organização biológica (molecular, fisiológico, indivíduo), mesmo que em baixas concentrações de contaminantes (Moore, 1990).

Em nível celular, os lisossomos (responsáveis pela digestão intracelular e processos de defesa contra patógenos e transporte de nutrientes) têm sido identificados como alvo de efeito de vários contaminantes. Alterações patológicas nos lisossomos, como mudanças na integridade e permeabilidade de membranas, têm sido utilizadas para identificação dos primeiros sinais de efeitos adversos de substâncias químicas no ambiente aquático (Pereira et al., 2008; Cortez et al., 2012; Gaspar, 2015), uma vez que a integridade e estabilidade de membranas lisossômicas é considerada um indicador de "bem estar" celular (Moore et al., 2007).

Segundo Lowe e colaboradores (1995), os efeitos na integridade e permeabilidade de membranas podem ser observados nos lisossomos através da transferência de substratos, como por exemplo, a troca de íons do citosol para os lisossomos. $\mathrm{O} \mathrm{pH}$ ácido no interior dos lisossomos é mantido pelo influxo de íons $\mathrm{H}^{+}$mantido pela bomba de prótons. A diminuição da atividade da bomba de prótons, causado por estresse frente ao acumulo de contaminantes nos lisossomos, conduzirá a um aumento do $\mathrm{pH}$ intralisossomal, resultando num gradiente de equilibro, liberando a passagem dos 
componentes dos lisossomos para o citosol. Desta forma, quando o lisossomo entra em contato com um contaminante, é observado o efluxo dos conteúdos do lisossoma para ao citosol, refletindo assim o comprometimento do processo fisiológico normal (Lowe et al., 1995).

A ocorrência de efeitos nos lisossomos pode ser mensurada por meio do método de ensaio denominado Tempo de Retenção do Corante Vermelho Neutro (TRCVN), considerado um biomarcador de efeito.

O corante vermelho neutro é uma base fraca que, na sua forma não protonada, permeia a membrana lisossomal. Desta forma, bases fracas como o vermelho neutro induzem alterações estruturais em lisossomos, incluindo inchaço e vacuolização, que resultam num aumento da autofagia e quebra da membrana. Neste sentido, o TRCVN em hemócitos de moluscos tem sido utilizado a fim de se detectar danos e alterações na permeabilidade de membranas lisossômicas, que ocorrerem em função da exposição a contaminantes (Lowe et al., 1995).

O ensaio para avaliação do TRCVN baseia-se no princípio de que os lisossomos de células saudáveis conseguem reter o corante vermelho neutro, por um certo período de tempo, enquanto danos na integridade e estabilidade da membrana lisossomal, causados pela exposição a xenobióticos, diminui o tempo de retenção do corante, induzindo o vazamento de componentes do lisossoma para o citosol mais rapidamente (Dailianis et al., 2003).

Os três compostos analisados (TCS, EE2 e IBU) apresentaram diminuição significativa na estabilidade de membranas lisossômicas dos mexilhões $M$. charruana em concentrações ambientalmente relevantes $\left(0,08-0,024-0,15 \mathrm{ng} \cdot \mathrm{g}^{-1}\right.$, respectivamente). Estes resultados sugerem um cenário crítico, uma vez que, de acordo com Ringwood et al. (2004), o estresse celular provocado pela exposição parental a xenobióticos pode causar efeitos na viabilidade de gametas de bivalves marinhos e, consequentemente, afetar o sucesso reprodutivo dessas populações a longo prazo, especialmente por estes compostos serem introduzidos de maneira contínua no ambiente. O desenvolvimento embriolarval de alguns invertebrados (e.g. ouriços-do-mar, mexilhões, etc.) é dependente 
de vitelo, que libera energia para a larva por meio da degradação do mesmo pelos lisossomos que, por sua vez, se estiverem comprometidos por conta do estresse celular, pode retardar ou inviabilizar o desenvolvimento das larvas.

Além disso, esses efeitos podem estar relacionados ao mecanismo de ação dos compostos analisados. A toxicidade de bactericidas como o triclosan é mediada, pelo menos em parte, por meio de efeitos membranotrópicos, o que resulta na desestabilização de suas estruturas, gerando maior permeabilidade e danos na integridade de membranas celulares (Villalaín et al., 2001), o que foi observado no ensaio do TRCVN. Cortez e colaboradores (2012) observaram efeitos semelhantes por meio da exposição de mexilhões Perna perna a concentrações ambientalmente relevantes em águas marinhas superficiais $\left(1,2 \mu \mathrm{g} \cdot \mathrm{L}^{-1}\right)$. Por outro lado, o ibuprofeno possui a capacidade, em doses terapêuticas, de estabilizar membranas lisossomais em mamíferos, por conta do seu mecanismo de ação anti-inflamatória (Smith et al., 1976; Flynn et al., 1984), mas em altas concentrações pode provocar uma redução significativa na estabilidade dessas membranas (Philips and Muirden, 1972). Entretanto, essa redução na estabilidade de membranas lisossomais provocada pelo ibuprofeno não se limita apenas a mamíferos. Aguirre-Martínez e colaboradores (2013b) demonstraram efeitos na estabilidade de membranas lisossomais em organismos marinhos, como mariscos $R$. philippinarum após 7 dias de exposição ao ibuprofeno em concentrações de $15 \mu \mathrm{g} . \mathrm{L}^{-1}$ a $50 \mu \mathrm{g} \cdot \mathrm{L}^{-1}$. O caranguejo da espécie Carcinus maenas reduziu em 50\% a estabilidade das membranas lisossomais, quando comparado a organismos saudáveis, após 28 dias de exposição ao ibuprofeno $\left(5 \mu \mathrm{g} \cdot \mathrm{L}^{-1}\right)$, a carbamazepina $\left(1 \mu \mathrm{g} \cdot \mathrm{L}^{-1}\right)$ e o novobiocin (1 $\left.\mu \mathrm{g} . \mathrm{L}^{-1}\right)$ em água do mar (Aguirre-Martínez et al., 2013c).

Recentemente, Pereira et al. (2014) demonstraram que o estresse fisiológico está associado a alterações da estrutura da comunidade bentônica e deterioração do estado ecológico ao longo do tempo. Desta forma, uma vez que o estresse celular pode ser relacionado a efeitos em níveis mais elevados de organização biológica, o que pode afetar a aptidão ecológica dessas populações, o uso de biomarcadores torna-se uma importante linha de evidência para avaliações de risco mais consistentes. 
Uma vez que os FPCP são absorvidos pelos organismos, o metabolismo de fase I fica responsável por transformar compostos apolares e hidrofóbicos em compostos mais solúveis para serem mais facilmente excretados. A modulação do metabolismo mediado pelo citocromo P450 (CYP450) é o mais importante mecanismo de interação com drogas (Quinn et al., 2004). A CYP450 introduz uma hidroxila (radical livre) no composto (monooxigenase) e para isso, gera espécies reativas de oxigênio (ERO), podendo contribuir para um aumento do estresse oxidativo. Embora vários citocromos estejam envolvidos na metabolização de produtos farmacêuticos em humanos, o citocromo P450 3A4 (CYP3A4) é o mais abundante do citocromo P450 e, além disso, é responsável pelo metabolismo de mais de $60 \%$ de todas as drogas clinicamente relevantes (Lin et al., 2002), incluindo os compostos analisados no presente estudo. Até o momento, a presença de CYP3A-like em M. charruana ainda não foi analisada, entretanto é possível que ocorra uma vez que outros bivalves são responsivos a essas enzimas (Gagné et al., 2007). Além disso, existe a necessidade de estudos moleculares com este organismo para elucidar as enzimas específicas envolvidas na metabolização de fármacos.

O triclosan ativou a fase I do metabolismo de biotransformação do $M$. charruana após $24 \mathrm{~h}$ de exposição ao sedimento marcado, onde foi evidenciado aumento na atividade da DBF na concentração de $0,75 \mathrm{ng} \cdot \mathrm{g}^{-1}$ quando analisada as brânquias dos organismos expostos. Já a análise das glândulas digestivas evidenciou diminuição das atividades relacionadas à fase II e sistema antioxidante $\left(0,01-0,08-0,75 \mathrm{ng} \cdot \mathrm{g}^{-1}\right)$. Resultados semelhantes foram reportados por Maranho et al. $(2014 ; 2015 \mathrm{c})$ onde a exposição por 14 dias ao propranolol também diminuiu a atividade da GST em poliquetas, assim como após exposição por 10 dias do anfípode Ampelisca brevicornis ao EE2. Estudos prévios reportaram diminuição da GPx em siris, mariscos e peixes após a exposição a pesticidas, PCBs e metais (Faria et al., 2009; Damásio et al., 2010). De acordo com Damásio (2010) e Milan et al. (2013), falhas no mecanismo de defesa antioxidante para remoção de espécies reativas de oxigênio produzidas pela exposição a poluentes, seja por inibição ou pelo excesso de radicais livres, pode perturbar 0 equilíbrio entre o sistema antioxidade / pró-oxidante, gerando estresse oxidativo, o que pode implicar no aumento da peroxidação lipídica. Os resultados do presente estudo demonstraram aumento da LPO $\left(0,08-0,75 \mathrm{ng} \cdot \mathrm{g}^{-1}\right)$ e dos níveis de danos em DNA $(0,01$ 
$\mathrm{ng} \cdot \mathrm{g}^{-1}$ ), evidenciando o efeito oxidativo provocado pelo TCS. Resultados semelhantes foram obtidos em estudo realizado por Quinn et al. (2011), o qual observou aumento da LPO e danos em DNA em apenas 24 horas de exposição ao gemfibrozil em concentrações de 1 e $1000 \mu \mathrm{g} \cdot \mathrm{L}^{-1}$.

A exposição do $M$. charruana por $24 \mathrm{~h}$ a sedimentos contaminados com ibuprofeno não ativou a fase I do metabolismo. A ativação da fase I foi observada por Maranho e colaboradores (2014) através de uma sutil inibição da DBF após 14 dias de exposição do poliqueta Hediste diversicolor ao IBU em concentrações de 0,5 e $50 \mathrm{ng} \cdot \mathrm{g}^{-1}$. Com relação a fase II, o mesmo estudo demonstrou que não houve alteração significativa da GST após 14 dias de exposição, assim como os resultados observados no presente estudo para essa enzima. Por outro lado, a atividade do sistema antioxidante foi aumentada nas concentrações de 0,15 e 1,51 ng.g-1 ${ }^{-1}$, corroborando com os resultados obtidos por AguirreMartínez e colaboradores (2013a) após a exposição de caranguejo Carcinus maenas. Em estudo realizado por Milan et al. (2013), outras enzimas envolvidas no sistema antioxidante do marisco Ruditapes philippinarum, como a superoxidismutase (SOD), demonstraram diminuição das defesas antioxidantes após exposição por 1, 3, 5 e 7 dias ao ibuprofeno. Já Gonzalez-Rey \& Bebianno (2011), analisaram a mesma enzima após a exposição do mexilhão Mytilus galloprovincialis ao IBU e observou aumento nos 7 primeiros dias, entretanto, após 15 dias de exposição, a atividade foi reduzida ao mesmo nível do grupo controle.

De acordo com Maranho et al. (2015d), variações no mecanismo de defesa antioxidante podem ter, como consequência, efeitos na estabilidade de membranas lisossômicas, o que foi observado nos ensaios de citotoxicidade (TRCVN). Embora concentrações ambientais de IBU tenham ativado o sistema antioxidante dos mexilhões, não foram observados peroxidação lipídica e danos em DNA.

Embora o EE2 tenha apresentado efeitos tóxicos mais severos nos ensaios de toxicidade tradicionais e na desestabilização da membrana lisossômica do que o TCS e IBU, foi o composto menos responsivo para as atividades metabólicas analisadas, tanto no tecido branquial, como na glândula digestiva. Entretanto, foi evidenciado aumento na 
atividade da fase I do metabolismo através do aumento da DBF nas glândulas digestivas $\left(0,024-0,237 \mathrm{ng} \cdot \mathrm{g}^{-1}\right)$, e aumento nos níveis de danos em DNA quando analisado as brânquias dos organismos expostos às concentrações de $0,237 \mathrm{ng} \cdot \mathrm{g}^{-1}$. Maranho et al. (2014) observaram ativação da fase I do metabolismo, especialmente no que se refere a EROD, quando analisados poliquetas expostos por 14 dias a sedimentos marcados com EE2 nas concentrações de 0,01 a $10 \mathrm{ng} \cdot \mathrm{g}^{-1}$. Por outro lado, não foram observadas atividades da fase II nem do sistema antioxidante. O mesmo estudo demonstrou efeito oxidativo evidenciado pelo aumento da LPO apenas na concentração de 0,01 ng. $\mathrm{g}^{-1}$, enquanto concentrações mais altas $\left(0,1-1-10-100 \mathrm{ng} \cdot \mathrm{g}^{-1}\right)$ não apresentaram efeito significativo em relação ao grupo controle, assim como danos em DNA (Maranho et al., 2014).

De acordo com Notch et al. (2007), o EE2 é um forte promotor da formação de tumores hepáticos, que pode exercer efeitos co-carcinogênicos, através da redução da capacidade de um organismo de reparar adutos de DNA por meio da excisão de nucleotídeos. Nesse sentido, o aumento nos níveis de danos em DNA observado após a exposição do EE2 poderia estar relacionado a falha nesse processo de reparação, uma vez que trata-se da primeira etapa para remoção de uma variedade de lesões causadas pela formação de adutos mutagênicos (Notch et al., 2007). Embora estudos demonstrem que poucas horas de exposição a xenobióticos (de 6 a 24h em mexilhões) sejam suficientes para que ocorram efeitos em DNA, esses danos ainda podem ser reparados caso a exposição seja interrompida (Klobucâr, et al. 2003; Rigonato, et al. 2005; Michel \& Vincent-Hubert, 2015; Vignard, et al. 2015). Entretanto, considerando a pseudopersistência dos fármacos no ambiente (os compostos são introduzidos de forma contínua no ambiente), estes efeitos podem se estender a outros níveis de organização biológica.

No que diz respeito ao sistema nervoso, foi avaliado a ação dos PPCPs nas enzimas colinesterases (ChEs), que agem na função do neurotransmissor acetilcolina e quebram as junções neuromusculares, o que impede a ativação contínua do nervo, que é de fundamental importância para o bom funcionamento dos sistemas sensoriais e neuromusculares do corpo (Milan et al., 2013). Além disso, a indução da ChE 
desempenha um papel importante na apoptose (Zhang et al., 2002) que é de fundamental importância para a saúde dos organismos, uma vez que é responsável por vários processos fisiopatológicos (Thompson, 1995). Nesse sentido, alterações nas enzimas ChE pode comprometer diferentes funções fisiológicas, como fuga, locomoção, mudança no fechamento das conchas, taxa de filtração e alimentação, entre outros, o que a torna um importante biomarcador a ser avaliado (Viarengo et al., 2007). Diversos estudos demonstraram que a ChE em mexilhões pode ser inibida pela exposição a diferentes grupos de contaminantes, como metais, compostos organofosforados e farmacêuticos (Escartín \& Porte, 1997; Alves et al., 2002; Hamza-Chaffai et al., 1998; Milan et al., 2013). No presente estudo, em apenas 24 horas de exposição a concentrações ambientalmente relevantes do TCS $\left(0,01-0,08-0,75 n g \cdot g^{-1}\right)$ e IBU $\left(0,02 n g \cdot g^{-1}\right)$, foi observado a inibição da colinesterase. Resultados semelhantes foram observados por Milan et al. (2013), onde a exposição do marisco Ruditapes philippinarum ao IBU inibiram os níveis de AChE quando comparados com o grupo controle. O EE2 não apresentou efeitos neurotóxicos ao mexilhão $M$. charruana, corroborando os estudos realizados por Maranho et al. (2015c), no qual não foram observados efeitos após 10 dias de exposição de anfípodes a sedimentos contaminados com EE2, e por Souza et al. (2013), no qual foram expostos copépodes dulcícolas Eudiaptomus gracilis por 14 dias ao mesmo composto.

A ocorrência de efeitos inflamatórios em mexilhões pode ser mensurada por meio da análise da atividade da enzima ciclooxigenase (COX) (Gagné et al., 2007; Maranho, 2015b). A atividade enzimática da COX pode ser inibida por anti-inflamatórios não esteroidais (AINE) como o ibuprofeno (Maranho, 2015b).

A avaliação da COX após a exposição dos organismos não demonstrou variações significativas na atividade dessas enzimas, exceto o aumento na expressão da COX nos organismos expostos ao triclosan. Esperava-se inibição da atividade das enzimas COX após a exposição ao ibuprofeno por conta do seu mecanismo de ação anti-inflamatório, entretanto, não foi observado variação possivelmente devido a exposição a baixas concentrações por um período curto de tempo (24 horas). Em estudo realizado por Maranho e colaboradores (2015b), o IBU inibiu a atividade da COX após 14 dias de 
exposição do poliqueta Hediste diversicolor a sedimentos marcados em concentrações que variaram de 0,05 a $500 \mathrm{ng} \cdot \mathrm{g}^{-1}$.

Estudos indicam que a inibição da COX pode estar relacionada a atraso ou diminuição da desova de invertebrados. De acordo com Matsutani \& Nomura (1987), a desova de gametas de invertebrados no ambiente é ativada pela serotonina e prostaglandina que, por sua vez, são liberadas pela indução da COX. Entretanto, a indução da COX pode ocorrer por conta de estímulos mecânicos, térmicos e químicos. No que se refere ao aumento da indução da COX por estímulo térmico e mecânico, os mesmos podem ser relacionados a sazonalidade, uma vez que, no caso de mexilhões, na primavera e verão, a desova é atribuída a variações de temperatura e ao aumento da disponibilidade de alimentos (Camacho, 1991).

Por outro lado, o estímulo químico em invertebrados é pouco conhecido. Estudos sugerem que, em humanos, o aumento da expressão da COX-2, por conta de estímulo químico, pode estar relacionado com o desenvolvimento de câncer e, possivelmente, com a aquisição de um fenótipo invasivo e metastático (Hida et al., 1998; Takahashi et al., 2002; Carvalho et al., 2004).

Nesse sentido, a avaliação da COX torna-se mais uma evidencia indireta de efeitos em níveis mais elevados de organização biológica, uma vez pode afetar a desova e, consequentemente, o sucesso reprodutivo de invertebrados marinhos quando inibida. Existe a necessidade de estudos para avaliação dos efeitos da indução da COX em invertebrados marinhos.

Embora os biomarcadores empregados no presente estudo tenham sido responsivos aos FPCP, não permitiram elucidar de forma clara as vias metabólicas e de excreção dos FPCP nos mexilhões $M$. charruana, provavelmente por conta do curto período de exposição ao qual os organismos foram submetidos. Entretanto, mesmo com apenas 24 horas de exposição foi possível observar que o TCS causou efeitos citogenotóxicos (diminuição da estabilidade da membrana lisossomal, peroxidação lipídica e danos em DNA) e neurotóxicos. O IBU causou efeitos citotóxicos e neurotóxicos, enquanto o EE2 apresentou efeitos cito-genotóxicos. Nesse sentido, mesmo em baixas 
concentrações e curtos períodos de exposição, os FPCP são potencialmente capazes de alterar os mecanismos de manutenção da homeostase.

Diante das respostas bioquímicas observadas no presente estudo, com exposição de $M$. charruana por $24 \mathrm{~h}$ a sedimentos marcados com concentrações ambientalmente relevantes de TCS, IBU e EE2, foi constatada a necessidade de estudos com esse organismo sentinela por um período prolongado de exposição, a fim de se elucidar de forma mais clara os mecanismos de biotransformação, excreção e estresse provocado pela exposição desses FPCP a invertebrados marinhos bentônicos. As alterações nas atividades de fase I e ll do metabolismo, assim como no sistema antioxidante e evidências de efeito oxidativo, somado aos altos valores do coeficiente de partição octanol/água (Kow), que favorecem os processos de absorção e bioacumulação, reforçam a necessidade de estudos relacionados a bioacumulação e possível biomagnificação desses compostos.

Com relação aos biomarcadores empregados no presente estudo, o método do tempo de retenção do corante vermelho neutro, que avalia a integridade e estabilidade de membranas lisossômicas, apresentou respostas mais consistentes em relação aos demais métodos. As respostas observadas foram tão sensíveis quanto os outros métodos empregados e ainda possuem relação direta com efeitos em níveis mais elevados de organização biológica e maior relevância ecológica. A aplicação desta técnica demonstrou-se mais simples e econômica, demandando menos tempo, infraestrutura e recursos em relação aos demais biomarcadores. Além disso, trata-se de um método bem consolidado e já empregado em programas de monitoramento ambiental de diferentes países (UNEP, 1999; OSPAR, 2012).

O mexilhão Mytella charruana apresentou grande sensibilidade aos FPCPs nos ensaios cito-genotóxicos, demonstrando ser uma espécie modelo adequada para estudos sobre a qualidade ambiental de regiões tropicais e subtropicais. Além disso, são excelentes representantes de ecossistemas bentônicos, onde vivem enterrados ou sob os sedimentos, e uma alternativa de espécie sentinela para avaliação e monitoramento 
da qualidade de sedimentos marinhos e estuarinos, onde se concentram grandes centros urbanos, atividades portuárias e industriais.

\subsection{Avaliação de risco ambiental}

A avaliação do risco ambiental de FPCP realizada no presente estudo ocorreu de acordo com protocolo da EMEA (2006), partindo diretamente para a Fase II - TIER B, uma vez que os compostos analisados têm tendência a acumular em sedimentos por serem hidrofóbicos, apresentarem valores de $\mathrm{K}_{\text {ow }}$ elevados, e tempo de meia-vida de várias semanas em sedimentos.

Para realização da avaliação, foi incialmente determinada a exposição da biota aos FPCP de interesse (TCS, IBU e EE2), a partir de concentrações ambientais mensuradas (MEC) em sedimentos provenientes da área de influência do emissário submarino de Santos - São Paulo, Brasil. Em seguida, foi avaliada a concentração de efeito para diferentes grupos de invertebrados marinhos bentônicos em uma bateria de bioensaios e, por último, foi determinado o quociente de risco para cada composto estudado.

Vale ressaltar que a seleção dos organismos utilizados nos ensaios, para posterior derivação de valores de PNEC, foi realizada de acordo com as considerações de Guérit et al. (2008), onde a derivação dos valores de PNEC deve ser baseada em dados ecotoxicológicos obtidos a partir de ensaios com espécies locais.

A partir dos resultados obtidos, foi possível estimar que o triclosan e o ibuprofeno apresentaram alto risco ambiental para invertebrados bentônicos. Embora o 17aetinilestradiol tenha apresentado toxicidade mais elevada em relação aos demais compostos, não foi possível estimar o risco ambiental, uma vez que o mesmo não foi detectado nos sedimentos das adjacências do ESS. Entretanto, vale ressaltar que as concentrações de efeito do EE2 foram consideravelmente mais baixas que o limite de detecção do método analítico empregado (LD > $33 \mathrm{ng} \cdot \mathrm{g}^{-1}$ ). Nesse sentido, é possível levar em consideração as concentrações ambientais de outros estudos, principalmente de regiões com características semelhantes. Froehner e colaboradores (2012) 
determinaram concentrações de EE2 em sedimentos de três regiões estuarinas no Brasil, que variaram de 0,11 a 129,78 $\mathrm{ng}^{-\mathrm{g}^{-1}}$. A estimativa do quociente de risco para o EE2, mesmo considerando a menor MEC obtida por este estudo $\left(0,11 \mathrm{ng} \cdot \mathrm{g}^{-1}\right)$, demonstra que este composto pode apresentar alto risco ambiental.

O estabelecimento de quocientes de risco tanto a nível individual (desenvolvimento embriolarval e reprodução) como sub-individuo (biomarcadores) demonstrou que os três compostos analisados apresentaram alto risco ambiental para invertebrados bentônicos.

Vale ressaltar que existem poucos estudos sobre risco ambiental de sedimentos contaminados com FPCP, nos quais foram utilizados PNECs estimados a partir de dados de toxicidade na água, considerando o método do equilíbrio de partição sedimento-água (Hernando et al., 2006; Nie et al., 2015). Porém, o uso de dados estimados, tanto de PNECs quanto de concentrações ambientais (Predicted Environmental Concentration PEC), pode subestimar ou superestimar o risco ambiental dos FPCP. Bouissou-Schurtz et al. (2014) demonstraram diferenças significativas nos valores de QR de IBU (por exemplo) quando comparados os índices PEC/PNEC (QR $=600,0)$ e MEC/PNEC (QR = 1,9). Desta forma, avaliações de risco ambiental mais realistas em sedimentos devem considerar 0 uso de concentrações ambientais mensuradas, bem como 0 estabelecimento de PNECs a partir de resultados de ensaios de toxicidade em sedimentos e avaliando diferentes níveis de organização biológica.

Em 2008, Guérit e colaboradores, sugeriram que para a avalição de risco ambiental de substâncias específicas, como pesticidas e herbicidas, o PNEC deve ser derivado de ensaios que levem em consideração o mecanismo de ação dos compostos para organismos-alvo de forma prioritária, a fim de se obter respostas mais realistas para uma tomada de decisão (Guérit et al., 2008). Entretanto, no caso de FPCP, estudos recentes demonstraram que ensaios orientados pelo mecanismo de ação dos compostos devem ser considerados também em organismos não-alvo (Martin-Diaz et al., 2009; Cortez et al., 2012; Gaspar, 2015), uma vez que respostas mais sensíveis podem ser observadas. 
Neste sentido, levando-se em consideração o mecanismo de ação dos compostos analisados, os resultados obtidos no presente estudo seguiram esta tendência. $O$ hormônio sintético EE2 apresentou efeito mais severo nos ensaios para avaliação do desenvolvimento embriolarval com ouriço-do-mar e mexilhões quando comparado aos demais compostos, uma vez que pode diminuir a qualidade, a fertilidade e a fecundidade de gametas, além atuar diretamente na indução de vitelogenina em machos (Fenske et al., 2005). Já o TCS e o IBU, que agem diretamente em membranas celulares por meio de efeitos membranotrópicos e desestabilização de membranas lisossômicas, apresentaram aumento significativo no efeito quando realizado o ensaio para avaliação da citotoxicidade, no qual foram avaliadas perturbações na integridade da membrana lisossomal.

Embora existam estudos sobre a toxicidade e persistência de FPCP no ambiente, estes não precisam ser persistentes para apresentar toxicidade, uma vez que são liberados de maneira contínua para os ecossistemas aquáticos (Muñoz et al., 2008). Estudos demonstram que as estações de tratamento de água e esgoto não removem completamente estes compostos (Lindström et al., 2002; Singer et al., 2002; Venkatesan et al., 2012; Carmona et al., 2014).

Este cenário se torna ainda mais grave em se tratando de países emergentes como o Brasil, o qual $55 \%$ das cidades possuem coleta de esgoto, e apenas $51 \%$ do esgoto coletado sofre algum tipo de tratamento (IBGE, 2008). De forma geral, as ETEs no Brasil são projetadas apenas para diminuição da carga orgânica dos efluentes. $\mathrm{Na}$ região da baía de Santos, embora o índice de coleta de esgoto seja de 98\% em Santos e 74\% em São Vicente (CETESB, 2014), existem habitações irregulares, como palafitas sem escoamento sanitário adequado. Além disso, todo o esgoto coletado na cidade de Santos e São Vicente recebem apenas um pré-condicionamento, o qual consiste em gradeamento e cloração e, posteriormente, é descartado por meio do Emissário Submarino de Santos.

No final de 2006, entrou em vigor uma política da União Europeia para o uso de substâncias químicas, denominado REACH, (Registration, Evaluation, Authorisation and 
Restriction of Chemical substances) (European Union, 2006). O REACH é um sistema integrado único que tem como objetivo aumentar a proteção à saúde humana e ao meio ambiente através de um melhor conhecimento das substâncias químicas comercializadas, uma vez que exige uma série de testes físicos, químicos e biológicos para liberação dos produtos, assim como a tomada das medidas necessárias para gerir todos os riscos que forem identificados. Essa diretiva abre caminho para uma maior competitividade e inovação das indústrias de produtos químicos, sintetizando compostos cada vez mais eficientes e menos tóxicos ao meio ambiente e à saúde humana, tanto para países da União Europeia, como outros não integrantes que pretendam exportar seus produtos.

Nesse sentido, alguns compostos com propriedades fitoterápicas, por exemplo, já foram testados e apresentaram resultados promissores. Toma e colaboradores (2014) realizaram análise do óleo de Cártamo (Carthamus tinctorius), o qual, além de apresentar propriedades antiulcerogênicas significativas para o controle de úlcera gástrica, não apresentou efeitos tóxicos para organismos aquáticos, diferentemente do composto sintético.

Recentemente, a Comissão Europeia, no âmbito da Diretiva 2013/39/UE, que altera as Diretivas 2000/60/CE e 2008/105/CE, estabeleceu uma lista de substâncias químicas prioritárias no domínio da política da água, as quais constituem risco significativo para o ambiente aquático (EC, 2013). A Diretiva também estabelece uma lista de vigilância, a qual inclui o 17a-etinilestradiol e diclofenaco, com intuito de recolher dados de monitorização para facilitar a determinação das medidas adequadas para fazer face ao risco que essas substâncias constituem. Para isso, serão considerados dados de monitoramento ambiental, de projetos de pesquisa, dos volumes de produção, padrões de utilização, propriedades intrínsecas (incluindo, se pertinente, o tamanho das partículas), das concentrações ambientais e de efeitos. De acordo com os resultados obtidos no presente estudo, o triclosan, ibuprofeno e 17a-etinilestradiol devem ser incluídos na lista de compostos prioritários na próxima revisão da Diretiva, prevista para ocorrer no máximo quatro anos após da entrada em vigor da presente diretiva (EC, 2013). 
Diante deste contexto, torna-se de fundamental importância o desenvolvimento de estudos que apontem os riscos dos FPCP, assim como 0 incentivo para 0 desenvolvimento de novos compostos, tão eficientes quanto os já sintetizados e comercializados, porém menos tóxicos e com degradação mais rápida no ambiente.

Algumas medidas podem ser tomadas no sentido de minimizar a ocorrência e os efeitos dos FPCP nos ecossistemas. Mudanças em curto prazo que poderiam ser adotadas, como a venda de medicamentos fracionados e coleta de medicamentos vencidos por parte de farmácias, drogarias e hospitais, como já ocorre em algumas cidades, poderiam contribuir para diminuição do aporte destes compostos ao ambiente. $\mathrm{O}$ aumento na rede coletora esgoto, juntamente com a melhora na eficiência das ETEs, são medidas que, a médio prazo, resultariam em diminuição da ocorrência dos FPCP no ambiente. Além disso, o controle de efluentes hospitalares e de indústrias farmacêuticas poderia reduzir o aporte desses contaminantes no ambiente, uma vez que são descartados na rede coletora de esgotos sem tratamento prévio. Estudos demonstram que o uso de radiação ionizante, por exemplo, reduz a toxicidade de efluentes, inclusive de fármacos (Moraes et al., 2004; Santos, 2012; Borrely et al., 2016). Neste sentido, a instalação de estações de tratamento específicas nesses setores poderia reduzir significativamente o aporte dos FPCP na rede de esgoto, que é a principal via de entrada no ambiente.

Já em longo prazo, existe a necessidade de incentivo a estudos e regulamentação relacionadas ao desenvolvimento de fármacos e produtos de cuidados pessoais, a fim de torna-los facilmente degradáveis e menos agressivos a organismos não-alvos, bem como garantir a responsabilidade sócio ambiental das empresas quanto aos riscos de novos compostos inseridos no mercado e a destinação final. 


\section{CONCLUSÕES}

$\checkmark \quad$ Considerando a necessidade de estudos para avaliação de risco ambiental de FPCP em sedimentos marinhos de ambientes tropicais e subtropicais, o presente estudo apresenta os primeiros dados realizados na América Latina que emprega concentrações ambientais mensuradas e efeitos biológicos em diferentes níveis de organização empregando sedimentos marcados;

$\checkmark \quad$ As concentrações de triclosan e ibuprofeno detectadas nos sedimentos da área de influência do emissário submarino de Santos foram de 15,14 e 49,0 ng.g ${ }^{-1}$, respectivamente, enquanto o $17 \alpha$-etinilestradiol não foi detectado (LD $<33,3$ ng. $\left.\mathrm{g}^{-1}\right)$;

$\checkmark \quad$ O triclosan, ibuprofeno e o 17a-etinilestradiol causaram toxicidade aos embriões do ouriço-do-mar Lytechinus variegatus e do mexilhão Perna perna em concentrações ambientalmente relevantes;

$\checkmark \quad$ Mesmo em baixas concentrações, o triclosan, o ibuprofeno e o 17a-etinilestradiol, são potencialmente capazes de alterar os mecanismos de manutenção da homeostase de mexilhões Mytella charruana, uma vez que foi evidenciado alterações no metabolismo de biotransformação de Fases I e II e no sistema de defesa antioxidante;

$\checkmark$ Com apenas 24 horas de exposição, os compostos analisados no presente estudo causaram efeitos cito-genotóxicos e neurotóxicos em mexilhões Mytella charruana em concentrações ambientalmente relevantes. O triclosan causou efeitos cito-genotóxicos (diminuição da estabilidade da membrana lisossomal, peroxidação lipídica e danos em DNA) e neurotóxicos. O IBU causou efeitos citotóxicos e neurotóxicos, enquanto o EE2 apresentou efeitos cito-genotóxicos;

$\checkmark \quad$ O mexilhão Mytella charruana demonstrou ser uma espécie modelo adequada para estudos sobre a qualidade ambiental de regiões tropicais e subtropicais, e é uma excelente alternativa de espécie sentinela para avaliação e monitoramento da qualidade de sedimentos marinhos e estuarinos;

$\checkmark \quad$ Os protocolos de avaliação de risco ambiental devem contemplar o uso de biomarcadores, garantindo assim a proteção e manutenção das comunidades 
aquáticas, uma vez que são indicadores de estado pré-patológico dos organismos;

$\checkmark \quad$ Os três compostos analisados (triclosan, ibuprofeno e 17q-etinilestradiol) apresentaram alto risco ambiental e devem ser considerados em legislações futuras, em políticas de gerenciamento ambiental e de resíduos, bem como no tratamento de efluentes, a fim de minimizar os possíveis impactos ambientais. 


\section{REFERÊNCIAS BIBLIOGRÁFICAS}

ABESSA, D.M.S. 1996. Testes de toxicidade de sedimentos da região de Santos-SP, Brasil, (24S,46W), utilizando o anfípodo escavador Tiburonella viscana (CrustaceaPlatyischnopidae) Thomas \& Barnard (1983). Dissertação de Mestrado. Instituto Oceanográfico da Universidade de São Paulo, SP. 97p.

ABESSA, D.M.S. 2002. Avaliação da qualidade de sedimentos do Sistema Estuarino de Santos, SP, Brasil. Tese de Doutorado. Instituto Oceanográfico da Universidade de São Paulo, SP. 290p.

ABNT - ASSOCIAÇÃO BRASILEIRA DE NORMAS TÉCNICAS. 2012. NBR 15350: ecotoxicologia aquática: toxicidade crônica de curta duração - método de ensaio com ouriço-do-mar (Echinodermata: Echinoidea). Rio de Janeiro, 19 p.

AGÜERA, A.; FERNÁNDEZ-ALBA, A.R.; PIEDRA, L.; MÉZCUA, M.; GÓMEZ, M.J. 2003. Evaluation of triclosan and biphenylol in marine sediments and urban wastewaters by pressurized liquid extraction and solid phase extraction followed by gas chromatography mass spectrometry and liquid chromatography mass spectrometry. Analytica Chimica Acta, 480:193-205p.

AGUIRRE-MARTÍNEZ, G.V.; DEL VALLS, T.A.; MARTÍN-DÍAZ, M.L. 2013a. Identification of biomarkers responsive to chronic exposure to pharmaceuticals in target tissues of Carcinus maenas. Mar. Environ. Res., 87-88:1-11p.

AGUIRRE-MARTÍNEZ, G.V.; BURATTI, S.; FABBRI, E.; DEL VALLS, A.T.; MARTÍNDÍAZ, M.L. 2013b. Using lysosomal membrane stability of haemocytes in Ruditapes philippinarum as a biomarker of cellular stress to assess contamination by caffeine, ibuprofen, carbamazepine and novobiocin. Journal of Environmental Sciences, 25(7):1408-1418p.

AGUIRRE-MARTÍNEZ, G.V.; BURATTI, S.; FABBRI, E.; DEL VALLS, T.A.; MARTÍNDÍAZ, M.L. 2013c. Stability of lysosomal membrane in Carcinus maenas acts as a biomarker of exposure to pharmaceuticals. Environ Monit Assess., 185:3783-3793p. 
AGUNBIADE, F.O. \& MOODLEY, B. 2016. Occurrence and distribution pattern of acidic pharmaceuticals in surface water, wastewater, and sediment of the Msunduzi River, Kwazulu-Natal, South Africa. Environmental Toxicology and Chemistry, 35 (1):36-46p.

ALDA, M.J.L.; GIL, A.; PAZ, E.; BARCELÓ, D. 2002. Occurrence and analysis of estrogens and progestogens in river sediments by liquid chromatography-electrospraymass spectrometry. Analyst. 127:1299-1304p.

ALLMYR, M.; ADOLFSSON-ERICI, M.; MCLACHLAN, M.S; SANDBORGH-ENGLUND, G. 2006. Triclosan in plasma and milk from Swedish nursing mothers and their exposure via personal care products. Science of the Total Environment, 372:87-93p.

ALVES, S.R.C.; SEVERINO, P.C.; IBBOTSON, D.P.; DA SILVA, A.Z.; LOPES, F.R.A.S.; SÁENZ, L.A.; BAINY, A.C.D. 2002. Effects of furadan in the brown mussel Perna perna and in the mangrove oyster Crassostrea rhizophorae. Marine Environmental Research, 54:241-245p.

ANDERSON, B.S.; HUNT, J.W.; HESTER, M.M.; PHILLIPS, B.M. 1996. Assessment of sediment toxicity at the sediment-water interface. In: G.K. Ostrander, Techniques in aquatic toxicology (pp. 609-624). Boca Raton, FL: CRC Press.

ANGER, C.T.; SUEPER, C.; BLUMENTRITT, D.J.; MCNEILL,K.; ENGSTROM, D.R.; ARNOLD, W.A. 2013. Quantification of Triclosan, Chlorinated Triclosan Derivatives, and their Dioxin Photoproducts in Lacustrine Sediment Cores. Environ. Sci. Technol., 47:1833-1843p.

ANVISA - Agencia nacional de vigilância sanitária. 2004. RDC № 306, de 7 de dezembro de 2004. Dispõe sobre o Regulamento Técnico para o gerenciamento de resíduos de serviços de saúde.

ARIS, A.Z.; SHAMSUDDIN, A.S.; PRAVEENA, S.M. 2014. Occurrence of 17aethynylestradiol (EE2) in the environment and effect on exposed biota: a review. Environment International, 69:104-119p. 
ARNOLD, K.E.; BROWN, A.R.; ANKLEY, G.T.; SUMPTER, J.P. 2014. Medicating the environment: assessing risks of pharmaceuticals to wildlife and ecosystems. Phil. Trans. R. Soc. B 369: 20130569. http://dx.doi.org/10.1098/rstb.2013.0569

ARPIN-PONT, L.; BUENO, M.J.; GOMEZ, E.; FENET, H. 2016. Occurrence of PPCPs in the marine environment: a review. Environ Sci Pollut Res., 23(6):4978-4991p.

BAINY, A.C.D. 1995. Oxidative stress as a biomarker of polluted aquatic sites. In: VAL, A.L.; ALMEIDA-VAL. V.M.F.; RANDALL, D.J. Physiology and biochemistry of the fishes of the Amazon, C., 26:331-335p.

BAREL-COHEN, K.; SHORE, L.S.; SHEMESH, M.; WENZEL, A.; MUELLER, J.; KRONFELD-SCHOR, N. 2006. Monitoring of natural and synthetic hormones in a polluted river. Journal of Environmental Management, 78:16-23p.

BAYNE, B.L; CLARKE, K.R.; GRAY, J.S. 1988. Background and rationale to a pratical workshop on biological effects of pollutants. Mar. Eco. Prog. Ser., 46:1-5p.

BERETTA, M.; BRITTO, V.; TAVARES, T.M.; SILVA, S.M.T.; PLETSCH, A.L. 2014. Occurrence of pharmaceutical and personal care products (PPCPs) in marine sediments in the Todos os Santos Bay and the north coast of Salvador, Bahia, Brazil. J Soils Sediments, 14:1278-1286p.

BLAIR, B.D.; CRAGO, J.P.; HEDMAN, C.J.; KLAPER, R.D. 2013. Pharmaceuticals and personal care products found in the Great Lakes above concentrations of environmental concern. Chemosphere, 93:2116-2123p.

BORRELY, S.I.; MORAIS, A.V.; ROSA, J.M.; BADARÓ-PEDROSO, C.; PEREIRA, M.C.; HIGA, M.C. 2016. Decoloration and detoxification of effluents by ionizing radiation. Radiation Physics and Chemistry, 124:198-202p.

BOUISSOU-SCHURTZ, C.; HOUETO, P.; GUERBET, M.; BACHELOT, M.; CASELLAS, C.; MAUCLAIRE, A-C.; PANETIER, P.; DELVAL, C.; MASSET. D. 2014. Ecological risk 
assessment of the presence of pharmaceutical residues in a French national water survey. Regulatory Toxicology and Pharmacology, 3:296-303p.

BRADFORD, M.M. 1976. A rapid and sensitive method for the quantification of microgram quantities of protein utilizing the principle of protein-dye binding. Anal. Biochem., 72:248$254 p$.

BRAGA, O.; SMYTHE, G.A.; SCHÄFER, A.I.; FEITZ, A.J. 2005. Steroid estrogens in ocean sediments. Chemosphere, 61:827-833p.

BRASIL. CONAMA. Resolução n. 357, de 17 de março de 2005a. Dispõe sobre a classificação dos corpos de água e diretrizes ambientais para o seu enquadramento, bem como estabelece as condições e padrões de lançamento de efluentes, e dá outras providências. Diário Oficial da União: República Federativa do Brasil, Poder Executivo, Brasília, DF, n. 53, 18 março de 2005. Seção 1, p. 58-63.

BRASIL. CONAMA. Resolução № 358, de 29 de abril de 2005b. Brasília, Diário Oficial da União. Dispõe sobre o tratamento e a disposição final dos resíduos dos serviços de saúde e dá outras providências.

BRASIL. CONAMA. Resolução n. 430, de 13 de maio de 2011. Dispõe sobre as condições e padrões de lançamento de efluentes, complementa e altera a Resolução no 357, de17 de março de 2005, do CONAMA. Diário Oficial da União: República Federativa do Brasil, Poder Executivo, Brasília, DF, n. 92, 16 maio de 2011. p. 89.

BRASIL. CONAMA. Resolução no 454, de 01 de novembro de 2012. Brasília, Diário Oficial da União. Estabelece as diretrizes gerais e os procedimentos referenciais para 0 gerenciamento do material a ser dragado em águas sob jurisdição nacional.

BRAUSCH, J.M. \& RAND, G.M. 2011. A review of personal care products in the aquatic environment: Environmental concentrations and toxicity. Chemosphere, 82:1518-1532p. 
BREITHOLTZ, M. \& BENGTSSON, B.E. 2001. Oestrogens have no Hormonal Effect on the Development and Reproduction of the Harpacticoid Copepod Nitokra spinipes. Marine Pollution Bulletin, 42(10):879-886p.

CAMACHO, A.P. 1991. Cultivo del mejillón en la batea. In: CASASBELLAS, M.A.C., CAMACHO, A.P. \& FERNÁNDEZ (eds.) I. Unidades didácticas de acuicultura. Alva, 12, $53 p$.

CANTWELL, M.G.; WILSON, B.A.; ZHU, J.; WALLACE, G.T.; KING, J.W.; OLSEN, C.R.; BURGESS, R.M.; SMITH, J.P. 2010. Temporal trends of triclosan contamination in dated sediment cores from four urbanized estuaries: Evidence of preservation and accumulation. Chemosphere, 78:347-352p.

CARMONA, E.; ANDREU, V.; PICÓ, Y. 2014. Occurrence of acidic pharmaceuticals and personal care products in Turia River Basin: From waste to drinking water. Science of the Total Environment, 484:53-63p.

CARVALHO, W.A.; CARVALHO, R.D.S.; RIOS-SANTOS, F. 2004. Specific Cyclooxygenase-2 Inhibitor Analgesics: Therapeutic Advances. Rev Bras Anestesiol., 54(3):448-464p .

CESAR, A.; MARÍN-GUIRAO, L.; VITA, R.; MARÍN, A. 2002. Sensibilidad de anfípodos y erizos del Mar Mediterráneo a substancias tóxicas de referencia. Ciencias Marinas, 28(4): 407-417p.

CESAR, A.; MARÍN, A.; MARÍN-GUIRAO, L.; VITA, R. 2004. Amphipod and sea urchin tests to assess the toxicity of Mediterranean sediments: the case of Portmán Bay. Sci. Mar., 68(1):205-213p.

CESAR. A.; PEREIRA, C.D.S.; SANTOS, A.R.; ABESSA, D.M.S. 2006. Ecotoxicological assessment of sediments from the Santos and São Vicente estuarine system - Brazil. Brazilian Journal of oceonografy, 54(1):55-63p. 
CESAR, A.; CHOUERI, R.B.; RIBA, I.; MORALLES-CASELLES, M.C.; PEREIRA, C.D.S.; SANTOS, A.R.; ABESSA, D.M.S.; DELVALLS, T.A. 2007. Comparative sediment quality assessment in different littoral ecosystems from Spain (Gulf of Cadiz) and Brazil (Santos and São Vicente estuarine system). Environment International, 33:429-435p.

CETESB - Companhia de Tecnologia de Saneamento Ambiental. Sedimentos: Determinação da distribuição granulométrica. São Paulo: CETESB, 1995. Norma Técnica L6 160.

CETESB - Companhia de Tecnologia de Saneamento Ambiental. Relatório de qualidade das praias litorâneas no estado de São Paulo 2013. São Paulo : CETESB, 2014.

CHEUNG, C.C.C.; ZHENG, G.J.; LI, A.M.Y.; RICHARDSON, B.J.; LAM, P.K. 2001. Relationships between tissue concentrations of polycyclic aromatic hydrocarbons and antioxidative responses of marine mussels, Perna viridis. Aquat. Toxicol., 52:189-203p.

CHEUNG, V.V.; WEDDERBURN, R.J. \& DEPLEDGE, M.H. 1997. Molluscan lysossomal responses as a diagnostic tool for the detection of a pollution gradient in Tolo Harbor, Hong Kong. Mar. Env. Res., 46:273-241p.

CHOUERI, R.B.; CESAR, A.; ABESSA, D.M.S.; TORRES, R.J.; MORAIS, R.D.; RIBA, I.; PEREIRA, C.D.S.; NASCIMENTO, M.R.L.; MOZETO, A.A.; DELVALLS, T.A. 2009. Development of site-specific sediment quality guidelines for North and South Atlantic littoral zones: Comparison against national and international sediment quality benchmarks. Journal of Hazardous Materials, 170:320-331p.

CINIGLIA, C.; CASCONE, C.; GIUDICE, R.L.; PINTO, G.; POLLIO, A. 2005. Application of methods for assessing the geno- and cytotoxicity of Triclosan to C. ehrenbergii. Journal of Hazardous Materials, 122:227-232p.

CMS - CÂMARA MUNICIPAL DE SANTOS. 2014. Lei complementar ํำ 840, de 4 de julho de 2014. Dispõe sobre o descarte de medicamentos inservíveis em hospitais, postos de saúde, farmácias e estabelecimentos similares e dá outras providências. 
CONKLE, J.L.; GAN, J.; ANDERSON, M.A. 2012. Degradation and sorption of commonly detected PPCPs in wetland sediments under aerobic and anaerobic conditions. J Soils Sediments, 12:1164-1173p.

COONEY, J.D. 1995. Sediment Tests. In: RAND, G.M. Fundamentals of aquatic toxicology. Effects, environmental fate and risk assessment. Washington USA: Taylor \& Francis.

CORTEZ, F.S. 2011. Avaliação ecotoxicológica do fármaco triclosan para invertebrados marinhos. Dissertação de Mestrado. Instituto de Pesquisas Energéticas da Universidade de São Paulo. 203p.

CORTEZ, F.S.; PEREIRA, C.D.S.; SANTOS, A.R.; CESAR, A.; CHOUERI, R.B.; MARTINI, G.A.; BOHRER-MOREL, M.B. 2012. Biological effects of environmentally relevant concentrations of the pharmaceutical Triclosan in the marine mussel Perna perna (Linnaeus, 1758). Environ Pollut., 168:145-150p.

CRESPI, C.L.; MILLER, V.P.; PENMAN, B.W. 1997. Microtriter plate assays for inhibition of human, drug-metabolizing cytochromes P450. Anal. Biochem., 248:188-190p.

DAILIANIS, S.; DOMOUHTSIDOU, G.P.; RAFTOPOULOU, E.; KALOYIANNI, M.; DIMITRIADIS, V.K. 2003. Evaluation of neutral red retention assay, micronucleus test, acetylcholinesterase activity and a signal transduction molecule (cAMP) in tissues of Mytilus galloprovincialis (L.), in pollution monitoring. Marine Environmental Research, 56:443-470p.

DAMÁSIO, J.; NAVARRO-ORTEGA, A.; TAULER, R.; LACORTE, S.; BARCELO, D.; SOARES, A.M.V.M.; LÓPEZ, M.A.; RIVA, M.C.; BARATA, C. 2010. Identifying major pesticides affecting bivalve species exposed to agricultural pollution using multi-biomarker and multivariate methods. Ecotoxicology, 19:1084-1094p.

DAUTERMAN. 1994. Introduction to Biochemical Toxicology. IN: HODGSON, E \& LEVI, P.E. Connecticut: Appleton and Lange. 2a ed. 588p. 
DeLORENZO, M.E. \& FLEMING, J. 2008. Individual and Mixture Effects of Selected Pharmaceuticals and Personal Care Products on the Marine Phytoplankton Species Dunaliella tertiolecta. Arch Environ Contam Toxicol., 54:203-210p.

DUAN, Y-P.; DAI, C-M.; ZHANG, Y-L.; LING-CHEN. 2013. Selective trace enrichment of acidic pharmaceuticals in real water and sediment samples based on solid-phase extraction using multi-templates molecularly imprinted polymers. Analytica Chimica Acta, 758:93-100p.

DUSSAULT, È.B.; BALAKRISHNAN, V.K.; SVERKO, E.; SOLOMON, K.R.; SIBLEY, P.K. 2008. Toxicity of human pharmaceuticals and personal care products to benthic invertebrates. Environ Toxicol Chem., 27(2):425-432p.

EC - European Commission. 2003. Technical Guidance Document on Risk Assessment. TGD Parts II and III. Institute for Health and Consumer Protection. EUR 20418 EN/3.

EC - European Commission. 2010. SANCO/825/00 revision 8.1. Guidance document on pesticide residue analytical methods. European Commission, Directorate General Health and Consumer Protection.

EC - European Commission. 2013. Diretiva 2013/39/UE do Parlamento Europeu e do Conselho de 12 de agosto de 2013, que altera as Diretivas 2000/60/CE e 2008/105/CE no que respeita às substâncias prioritárias no domínio da política da água. Jornal Oficial da União Europeia.

EEA - European Environment Agency. 2010. Pharmaceuticals in the environment. Results of an EEA workshop. EEA Technical report, № 1/2010. ISSN EEA Technical report series 1725-2237. DOI 10.2800/31181.

ELLMAN, G.L.; COURTNEY, K.D.; ANDRES JR.; V.; FEATHERSTONE, R.M. 1961. A new and rapid colorimetrie determination of acetylcholinesterase activity. Biochem. Pharmacol., 7:88-95p. 
EMEA - European Medicines Evaluation Agency. 1998. European agency for the evaluation of medicinal products. Committee for Veterinary Medicinal Products (CVMP). Environmental Risk Assessment for Veterinary Medicinal Products other then GMO containing and Immunological Products. Ref EMEA/CVMP/055/96. London, UK.

EMEA - European Medicines Evaluation Agency. 2006. European agency for the evaluation of medicinal products. Committee for medicinal products for human use (CHMP). Guideline on the environmental risk assessment of medicinal products for human use. Ref EMEA/CRMP/SWP/4447/00. London, UK.

ENVIRONMENT CANADA. 2011. Pharmaceuticals and Personal Care Products Surveillance Network.

Disponível

em:

http://www.ec.gc.ca/scitech/default.asp?lang=en\&n=FDFE3DAA-1.

ESCARTÍN, E. \& PORTE, C. 1997. The use of cholinesterase and carboxylesterase activities from Mytilus galloprovincialis in pollution monitoring. Environmental Toxicology and Chemistry, 16:2090-2095p.

EUROPEAN UNION. 2006. Regulation (EC) № 1907/2006 of the European Parliament and of the Council of 18 December 2006. Official Journal of the European Union. Concerning the Registration, Evaluation, Authorization and Restriction of Chemicals (REACH), establishing a European Chemicals Agency, amending Directive 1999/45/EC and repealing Council Regulation (EEC) № 793/93 and Commission Regulation (EC) № 1488/94 as well as Council Directive 76/769/EEC and Commission Directives 91/155/EEC, 93/67/EEC, 93/105/EC and 2000/21/EC.

FABBRI, E. \& FRANZELLITTI, S. 2015. Human pharmaceuticals in the marine environment: focus on exposure and biological effects in animal species. Environmental Toxicology and Chemistry, 35(4):799-812p.

FARIA, M.; CARRASCO, L.; DIEZ, S.; RIVA, M.C.; BAYONA, J.M.; BARATA, C. 2009. Multi-biomarker responses in the freshwater mussel Dreissena polymorpha exposed to 
polychlorobiphenyls and metals. Comparative Biochemistry and Physiology, Part C, 149:281-288p.

FARRÉ, M.; ASPERGER, D.; KANTIANI, L.; GONZÁLEZ, S.; PETROVIC, M.; BARCELÓ, D. 2008. Assessment of the acute toxicity of triclosan and methyl triclosan in wastewater based on the bioluminescence inhibition of Vibrio fischeri. Anal Bioanal Chem., 390:19992007p.

FENSKE, M.; MAACK, G.; SCHÄFERS, C.; SEGNER, H. 2005. An environmentally relevant concentration of estrogen induces arrest of male gonad development in zebrafish, Danio rerio. Environmental Toxicology and Chemistry, 24(5):1088-1098p.

FENT, K.; WESTON, A.A.; CAMINADA D. 2006. Ecotoxicology of human pharmaceuticals. Aquat Toxicol., 76:122-59p.

FERRAZ, M.A. 2013. Desenvolvimento e aplicação de um método para a avaliação e identificação da toxicidade usando o organismo bentônico Nitocra sp (crustacea: copepoda: harpacticoida). Dissertação de Mestrado. Universidade Santa Cecília. 74p.

FLYNN, P.J.; BECKER, W.K.; VERCELLOTTI, G.M.; WEISDORF, D.J.; CRADDOCK, P.R.; HAMMERSCHMIDT, D.E.; LILLEHEI, R.C.; JACOB, H.S. 1984. Ibuprofen inhibits granulocyte responses to inflammatory mediators. A proposed mechanism for reduction of experimental myocardial infarct size. Inflammation, 8(1):33-44p.

FRANCIS, P.C.; BIRGE, W.J.; BLACK, J.A. 1984. Effects of cadmium-enriched sediment on fish and amphibian embryo-larval stages. Ecotoxicol. Environ. Saf., 8:378-387p.

FROEHNER, S.; MACHADO, K.S.; STEFEN, E.; BLEININGER, T.; DA ROSA, E.C.; MARTINS, C.D.C. 2012. Occurrence of selected estrogens in mangrove sediments. Mar Pollut Bull., 64(1):75-9p.

FUJIMOTO, Y.; SAKUMA, S.; INOUE, T.; UNO, E.; FUJITA, T. 2002. The endocrine disruptor nonylphenol preferentially blocks cyclooxygenase- 1. Life Sci., 70:2209-2214p. 
GAGNÉ, F. \& BLAISE, C. 1993. Hepatic metallothionein level and mixed function oxidase activity in fingerling rainbow trout (Oncorhynchus mykiss) after acute exposure to pulp and paper mill effluents. Water Research, 27:1669-1682p.

GAGNÉ, F.; TROTTIER, S.; BLAISE, C.; SPROULL, J.; ERNST, B. 1995. Genotoxicity of sediment extracts obtained in the vicinity creosote-treated wharf to rainbow trout hepatocytes. Toxicol. Lett., 78:175-182p.

GAGNÉ, F.; ANDRÉ, C.; CEJKA, P.; GAGNON, C.; BLAISE, C. 2007. Toxicological effects of primary-treated urban wastewaters, before and after ozone treatment, on freshwater mussels (Elliptio complanata). Comparative Biochemistry and Physiology, Part C, 145:542-552p.

GASPAR, J.C. 2015. Avaliação ecotoxicológica e do risco ambiental do fármaco ibuprofeno em invertebrados marinhos: uma abordagem com endpoints reprodutivos e de estresse celular. Dissertação de Mestrado. Universidade Federal de São Paulo. 81p.

GAUTAM, P.; CARSELLA, J.M.; KINNEY, C.A. 2014. Presence and transport of the antimicrobials triclocarban and triclosan in a wastewater-dominated stream and freshwater environment. Water Research, 48:247-256p.

GAW, S.; THOMAS, K.V.; HUTCHINSON, T.H. 2014. Sources, impacts and trends of pharmaceuticals in the marine and coastal environment. Phil. Trans. R. Soc. B. 369:20130572. DOI: 10.1098/rstb.2013.0572.

GEROLIN, E.R.R. 2008. Ocorrência e remoção de disruptores endócrinos em águas utilizadas para abastecimento público de Campinas e Sumaré - São Paulo. Tese de Doutorado. Universidade Estadual de Campinas. Faculdade de Engenharia Civil, Arquitetura e Urbanismo. 185p.

GHISELLI, G. 2006. Avaliação da Qualidade das Águas Destinadas ao Abastecimento Público na Região de Campinas: Ocorrência e Determinação dos Interferentes Endócrinos (IE) e Produtos Farmacêuticos e de Higiene Pessoas (PFHP). Tese de Doutorado (Ciências) - Universidade Estadual de Campinas, Campinas. 190 p. 
GONZALEZ-REY, M. \& BEBIANNO, M. J. 2011. Non-steroidal anti-inflammatory drug (NSAID) ibuprofen distresses antioxidant defense system in mussel Mytilus galloprovincialis gills. Aquatic Toxicology, 105:264-269p.

GREEN, R.E.; NEWTON, I.; SHULTZ, S.; CUNNINGHAM, A.A.; GILBERT, M.; PAIN, D.; PRAKASH, V. 2004. Diclofenac poisoning as a cause of vulture population declines across the Indian subcontinent. J. Appl. Ecol. 41:793-800.

GROS, M.; PETROVIC, M.; BARCELÓ, D. 2009. Tracing pharmaceutical residues of different therapeutic classes in environmental waters by using liquid chromatography/quadrupole-linear ion trap mass spectrometry and automated library searching. Anal. Chem., 81(3):898-912p.

GUÉRIT, I.; BOCQUENÉ, G.; JAMES, A.; THYBAUD, E.; MINIER, C. 2008. Environmental risk assessment: A critical approach of the European TGD in an in situ application. Ecotoxicology and Environmental Safety, 71:291-300p.

GUILHERMINO, L.; LOPES, M.C.; CARVALHO, A.P.; SOARES, A.M.V.M. 1996. Inhibition of acetylcholinesterase activity as effect criterion in acute tests with juvenile Daphnia magna. Chemosphere, 32(4):727-738p.

HALLGREN. P.; SORITA, Z.; BERGLUND, O.; PERSSON, A. 2012. Effects of 17aethinylestradiol on individual life-history parameters and estimated population growth rates of the freshwater gastropods Radix balthica and Bithynia tentaculata. Ecotoxicology, $21: 803-810 p$.

HAMZA-CHAFFAI, A.; ROMÉO, M.; GNASSIA-BARELLI, M.; EL ABED, A. 1998. Effect of copper and lindane on some biomarkers measured in the clam Ruditapes decussatus. Bulletin of Environmental Contamination and Toxicology, 61:397-404p.

HARRIES, J.E.; SHEAHAN, D.A.; JOBLING, S.; MATTHIESSEN, P.; NEALL, M.; SUMPTER, J.P.; TAYLOR, T.; ZAMAN, N. 1997. Estrogenic activity in five United Kingdom rivers detected by measurement of vitellogenesis in caged male trout. Environ Toxicol Chem. 16(3):534-542. 
HERNANDO, M.D.; MEZCUA, M.; FERNANDEZ-ALBA, A.R.; BARCELO, D. 2006. Environmental risk assessment of pharmaceutical residues in wastewater effluents, surface waters and sediments. Talanta, 69:334-342p.

HIDA, T.; YATABE, Y.; ACHIWA, H.; MURAMATSU, H.; KOZAKI, K-I; NAKAMURA, S.; OGAWA, M.; MITSUDOMI, T.; SUGIURA, T.; TAKAHASHI, T. 1998. Increased Expression of Cyclooxygenase 2 Occurs Frequently in Human Lung Cancers, Specifically in Adelincarcinomas. Cancer Research, 58:3761-3764p.

HINCK, J.E.; BLAZER, V.S.; SCHMITT, C.J.; PAPOULIAS, D.M.; TILLITT, D.E. 2009. Widespread occurrence of intersex in black basses (Micropterus spp.) from US rivers, 1995-2004. Aquat Toxicol. 95(1):60-70.

HIROTA, J. \& SZYPER, J.P. 1975. Separation of total particulate carbon into inorganic and organic components. Limnol Oceanogr., 20:896-900p.

HOFFMANN, J.L.; TORONTALI, S.P.; THOMASON, R.G.; LEE, D.M.; BRILL, J.L.; PRICE, B.B.; CARR, G.J.; VERSTEEG, D.J. 2006. Hepatic gene expression profiling using Genechips in zebrafish exposed to 17alpha-ethynylestradiol. Aquat Toxicol., 79(3):233-46p.

HUANG, X.; WU, C.; HU, H.; YU, Y; LIU, J. 2015. Sorption and degradation of triclosan in sediments and its effect on microbes. Ecotoxicology and Environmental Safety, 116:7683p.

HUBER, S.; REMBERGER, M.; KAJ, L.; SCHLABACH, M.; JÖRUNDSDÓTTIR, H.O.; VESTER, J.; ARNÓRSSON, M.; MORTENSEN, I.; SCHWARTSON, R.; DAM, M. 2016. A first screening and risk assessment of pharmaceuticals and additives in personal care products in waste water, sludge, recipient water and sediment from Faroe Islands, Iceland and Greenland. Science of the Total Environment, 562:13-25p.

HWANG, H.M.; WADE, T.L.; SERICANO, J.L. 2002. Relationship between lysosomal membrane destabilization and chemical body burden in eastern oyters Crassostrea 
virginica from Galveston Bay, Texas, USA. Environmental Toxicology and Chemistry, 21(6):1268-1271p.

IBGE - Instituto Brasileiro de Geografia e Estatística. 2008. Diretoria de Pesquisas, Coordenação de População e Indicadores Sociais, Pesquisa Nacional de Saneamento Básico. Disponível

em: http://www.ibge.gov.br/home/estatistica/populacao/condicaodevida/pnsb2008/defaulttab pdf_esgot_san.shtm.

JOBLING, S.; CASEY, D.; RODGERS-GRAY, T.; OEHLMANN, J.; SCHULTEOEHLMANN, U.; PAWLOWSKI, S.; BAUNBECK, T.; TURNER, A.P.; TYLER, C.R. 2003. Comparative responses of molluscs and fish to environmental estrogens and an estrogenic effluent. Aquat Toxicol., 65(2):205-220p.

JOBLING, S.; NOLAN, M.; TYLER, C.R.; BRIGHTY, G.; SUMPTER, J.P. 1998. Widespread sexual disruption in wild fish. Environ Sci Technol., 32:2498-2506.

KERRIGAN, J.F.; ENGSTROM, D.R.; YEE, D.; SUEPER, C.; ERICKSON, P.R.; GRANDBOIS, M.; MCNEILL, K.; ARNOLD, W.A. 2015. Quantification of Hydroxylated Polybrominated Diphenyl Ethers (OH-BDEs), Triclosan, and Related Compounds in Freshwater and Coastal Systems. PLOS ONE, doi:10.1371/journal.pone.0138805.

KIM, B.H.; TAKEMURA, A. 2003. Culture conditions affect induction of vitellogenin synthesis by estradiol-17 beta in primary cultures of tilapia hepatocytes. Comp. Biochem. Physiol, Part B Biochem. Mol. Biol., 135:231-239p.

KLOBUCÂR, G.I.V.; PAVLICA, M.; ERBEN, R.; PAPES, D. 2003. Application of the micronucleus and comet assays to mussel Dreissena polymorpha haemocytes for genotoxicity monitoring of freshwater environments. Aquatic Toxicology, 64:15-23p.

KOLPIN, D.; FURLONG, E.T.; MEYER, M.T.; et al. 2002. Pharmaceuticals, hormones, and other organic wastewater contaminants in U.S. streams, 1999-2000: A national reconnaissance. Environ Sci Technol., 36:1202-1211p. 
KUSTER, M.; ALDA, M.J.L.; BARCELÓ, D. 2004. Analysis and distribution of estrogens and progestogens in sewage sludge, soils and sediments. Trends in Analytical Chemistry, 23(10-11):790-798p.

LAMPARELLI, M.L.; COSTA, M.P.; PRÓSPERI, V.A. 2001. Sistema Estuarino de Santos e São Vicente. Relatório Técnico CETESB. São Paulo, SP. 178p.

LEI, B.; HUANG, S.; ZHOU, Y.; WANG, D.; WANG, Z. 2009. Levels of six estrogens in water and sediment from three rivers in Tianjin area, China. Chemosphere, 76:36-42p.

LIN, H-L.; KENT, U.M.; HOLLENBERG, P.F. 2002. Mechanism-Based Inactivation of Cytochrome P450 3A4 by 17a-Ethynylestradiol: Evidence for Heme Destruction and Covalent Binding to Protein. The Journal of Pharmacology and Experimental Therapeutics, 301(1):160-167p.

LINDSTRÖM, A.; BUERGE, I.J.; POIGER, T.; BERGQVIST, P.; MÜLLER, M.D.; BUSER, H. 2002. Occurrence and environmental behavior of the bactericide Triclosan and its methyl derivative in surface waters and in wastewater. Environ. Sci. Technol. 36:2322$2329 p$.

LORES, M.; LLOMPART, M.; SANCHEZ-PRADO, L.; GARCIA-JARES, C.; CELA, R. 2005. Confirmation of the formation of dichlorodibenzo-p-dioxin in the photodegradation of triclosan by photo-SPME. Short Communication. Anal Bioanal Chem., 381:1294$1298 p$.

LOWE, D.M.; SOVERCHIA, C.; MOORE, M.N. 1995. Lysosomal membrane responses in the blood and digestive cells of mussels experimentally exposed to fluoranthene. Aquatic Toxicology, 33:105-112p.

LUCZAK, C.; JANQUIN, M.A.; KUPKA, A. 1997. Simple standard procedures for the routine determination of organic matter in marine sediment. Hydrobiologia, 345:87-94p. 
MATSUTANI, T. \& NOMURA, T. 1987. In vitro effects of serotonin and prostaglandins on release of eggs from the ovary of the scallop, Patinopecten yessoensis. Gen. Comp. Endocrinol., 67:111-118p.

MARANHO, L.A.; GARRIDO-PÉREZ, M.C.; DELVALLS, T.A.; MARTÍN-DÍAZ, M.L. 2015a. Suitability of Standardized Acute Toxicity Tests for Marine Sediment Assessment: Pharmaceutical Contamination. Water Air Soil Pollut, 226:65. DOI 10.1007/s11270-0142273-6.

MARANHO, L.A.; ANDRÉ, C.; DELVALLS, T.A.; GAGNÉ, F.; MARTÍN-DÍAZ, M.L. 2015b. Toxicological evaluation of sediment samples spiked with human pharmaceutical products: Energy status and neuroendocrine effects in marine polychaetes Hediste diversicolor. Ecotoxicology and Environmental Safety, 118:27-36.

MARANHO, L.A.; MOREIRA, L.B.; BAENA-NOGUERAS, R.M.; LARA-MARTÍN, P.A.; DELVALLS, T.A.; MARTíN-DÍAZ, M.L. 2015c. A Candidate Short-Term Toxicity Test Using Ampelisca brevicornis to Assess Sublethal Responses to Pharmaceuticals Bound to Marine Sediments. Arch Environ Contam Toxicol., 68:237-258p.

MARANHO, L.A.; DELVALLS, T.A.; MARTÍN-DÍAZ, M.L. 2015d. Assessing potential risks of wastewater discharges to benthic biota: An integrated approach to biomarker responses in clams (Ruditapes philippinarum) exposed under controlled conditions. Marine Pollution Bulletin, 92:11-24p.

MARANHO, L.A.; BAENA-NOGUERAS, R.M.; LARA-MARTÍN, P.A.; DELVALLS, T.A.; MARTÍN-DÍAZ, M.L. 2014. Bioavailability, oxidative stress, neurotoxicity and genotoxicity of pharmaceuticals bound to marine sediments. The use of the polychaete Hediste diversicolor as bioindicator species. Environmental Research, 134:353-365p.

MARTIN-DIAZ, L.; FRANZELLITTI, S.; BURATTI, S.; VALBONESI, P.; CAPUZZO, A.; FABBRI, E. 2009. Effects of environmental concentrations of the antiepilectic drug carbamazepine on biomarkers and cAMP-mediated cell signaling in the mussel Mytilus galloprovincialis. Aquatic Toxicology, 94:177-185p. 
MATONGO, S.; BIRUNGI, G.; MOODLEY, B.; NDUNGU, P. 2015. Pharmaceutical residues in water and sediment of Msunduzi River, KwaZulu-Natal, South Africa. Chemosphere, 134:133-140p.

MCFARLAND, V.A.; INOUYE, S.L.; LUTZ, C.H.; JARVIS, A.S.; CLARKE, J.U.; MCCANT, D.D. 1999. Biomarkers of oxidative stress and genotoxicity in livers of field collected brown bullhead, Ameiurus nebulosus. Arch. Environ. Contam. Toxicol., 37:236-241p.

MICHEL, C. \& VINCENT-HUBERT, F. 2015. DNA oxidation and DNA repair in gills of zebra mussels exposed to cadmium and benzo(a)pyrene. Ecotoxicology, 24:2009-2016p.

MILAN, M.; PAULETTO, M.; PATARNELLO, P.; BARGELLONI, L.; MARIN, M.G.; MATOZZO, V. 2013. Gene transcription and biomarker responses in the clam Ruditapes philippinarum after exposure to ibuprofen. Aquatic Toxicology, 126:17-29p.

MONTAGNER, C.C. \& JARDIM, W.F. 2011. Spatial and Seasonal Variations of Pharmaceuticals and Endocrine Disruptors in the Atibaia River, São Paulo State (Brazil). Journal of the Brazilian Chemical Society, 22:1452-1462p.

MONTAGNER, C.C.; JARDIM, W.F.; VON DER OHE, P.C.; UMBUZEIRO, G.A. 2014. Occurrence and potential risk of triclosan in freshwaters of São Paulo, Brazil-the need for regulatory actions. Environ Sci Pollut Res., 21:1850-1858p.

MOORE, M.N. 1990. Lysosomal cytochemistry in marine environmental monitoring. Histochemical Journal, 22:187-191p.

MOORE, J.N.; BROOK, E.J.; JOHNS, C. 1989. Grain Size Partitioning of Metals in Contaminated, Coarse-Grained River Floodplain Sediment: Clark Fork River, Montana, USA. Environ Geol Water Sci., 14(2):107-115p.

MOORE, M.N. 1988. Cytochemical responses of the lysosomal systems and NADPHferrihemoprotein reductase in molluscan digestive cells to environmental and experimental exposure to xenobiotics. Mar. Ecol. Prog. Ser., 46:81-89p. 
MOORE, M.M.; LIVINGSTONE, D.R.; WIDDOWS, J.; LOWE, D.M.; PIPE, R.K. 1987. Molecular, cellular and physiological effects of oil-derived hydrocarbons on molluscs and their use in impact assessment. Phil. Trans. R. Soc. Lond. B, 316:603-623.

MOORE, M.N.; LOWE, D.M.; ALLEN, J.I.; MCVEIGH, A.; SOMERFIELD, P.J. 2007. Predicting health of the environment - lysosomal biomarker responses in mussels. In: Proceedings of the Workshop on the Med Pol Biological Effects Programme. United Nations Environment Programme/Mediterranean Action Plan (UNEP/MAP). Technical Reports Series Athens 166, 245p.

MORAES, M.C.F.; ROMANELLI, M.F.; SENA, H.C.; PASQUALINI DA SILVA, G.; SAMPA, M.H.O.; BORRELY, S.I. 2004. Whole acute toxicity removal from industrial and domestic effluents treated by electron beam radiation: emphasis on anionic surfactants. Radiation Physics and Chemistry, 71:461-463p.

MORALES, S.; CANOSA, P.; RODRÍGUEZ, I.; RUBÍ, E.; CELA, R. 2005. Microwave assisted extraction followed by gas chromatography with tandem mass spectrometry for the determination of triclosan and two related chlorophenols in sludge and sediments. Journal of Chromatography A, 1082:128-135p.

MOREIRA, D.S.; AQUINO, S. F.; AFONSO, R. J. C. F.; SANTOS, E.P.P.C.; PÁDUA, V.L. 2009. Occurrence of endocrine disrupting compounds in water sources of Belo Horizonte Metropolitan Area, Brazil. Environmental Technology, 30(10):1041-1049p.

MOREIRA, M.A.; AQUINO, S.F.; COUTRIM, M.X.; SILVA, J.C.C.; AFONSO, R.J.C.F. 2011. Determination of endocrine-disrupting compounds in waters from Rio das Velhas, Brazil, by liquid chromatography/high resolution mass spectrometry (ESILC-IT-TOF/MS). Environmental Technology, 32(11-12):1409-1417p.

MORIYAMA, K.; MATSUFUJI, H.; CHINO, M.; TAKEDA, M. 2004. Identification and behavior of reaction products formed by chlorination of ethynylestradiol. Chemosphere, 55:839-847. 
MUÑOZ, I.; GÓMEZ, M.J.; ANTONIO MOLINA-DÍAZ, A.; GARCÍA-CALVO, E. 2008. Ranking potential impacts of priority and emerging pollutants in urban wastewater through life cycle impact assessment. Chemosphere, 74:37-44p.

MULROY, A. When the cure is the problem. Water Environment Technology. 13(2): $32-$ 36. 2001.

NASSEF, M.; MATSUMOTO, S.; SEKI, M.; KHALIL, F.; KANG, I.J.; SHIMASAKI, Y.; OSHIMA, Y.; HONJO, T. 2010. Acute effects of triclosan, diclofenac and carbamazepine on feeding performance of Japanese medaka fish (Oryzias latipes). Chemosphere, 80:1095-1100p.

NEWMAN, M.C. \& UNGER, M.A. Fundamentals of Ecotoxicology. 2nd. Lewis Publishers. 2003.

NIE, M.; Yan, C.; Dong, W.; Liu, M.; Zhou, J.; Yang, Y. 2015. Occurrence, distribution and risk assessment of estrogens in surface water, suspended particulate matter, and sediments of the Yangtze Estuary. Chemosphere, 127:109-116p.

NOTCH, E.G.; MINIUTTI, D.M.; MAYER, G.D. 2007. 17a-Ethinylestradiol decreases expression of multiple hepatic nucleotide excision repair genes in zebrafish (Danio rerio). Aquatic Toxicology, 84(3):301-309p.

ORVOS, D. R.; VERSTEEG, D.J.; INAUEN, J.; CAPDEVIELLE, M.; ROTHENSTEIN, A.; CUNNINGHAM, V. 2002. Aquatic toxicity of Triclosan. Environmental Toxicology and Chemistry, 21:1338-1349p.

OSPAR - Oslo and Paris Comission. 2012. Review and update of the JAMP Technical Annex on lysosomal stability. ICES Advice 2012, Book 1.

OVERTURF, M.D.; ANDERSON, J.C.; PANDELIDES, Z.; BEYGER, L.; HOLDWAY, D.A. 2015. Pharmaceuticals and personal care products: A critical review of the impacts on fish reproduction. Crit Rev Toxicol., 45(6):469-91p. 
PALENSKE, N.M.; NALLANI, G.C.; DZIALOWSKI, E.M. 2010. Physiological effects and bioconcentration of Triclosan on amphibian larvae. Comp Biochem Physiol., Part C: Toxicol Pharmacol., 152(2):232-240p.

PEREIRA, C.D.S. 2008. Biomarcadores de exposição, efeito e bioacumulação de xenobióticos em mexilhões Perna perna (Linnaeus,1758) transplantados ao longo do litoral de São Paulo. Tese Doutorado. Instituto Oceanográfico da Universidade de São Paulo. 180p.

PEREIRA, C.D.S.; ABESSA, D.M.S.; CHOUERI, R.B.; ALMAGRO-PASTOR, V.; CESAR, A.; MARANHO, L.A.; MARTÍN-DÍAZ, M.L.; TORRES, R.J.; GUSSO-CHOUERI, P.K.; ALMEIDA, J.E.; CORTEZ, F.S.; MOZETO, A.A.; SILBIGER, H.L.; SOUSA, E.C.; DEL VALLS, T.A.; BAINY, A.C. 2014. Ecological relevance of Sentinels' biomarker responses: a multi-level approach. Mar Environ Res., 96:118-26p.

PEREIRA, C.D.S.; MARANHO, L.A.; CORTEZ, F.S.; PUSCEDDU, F.H.; SANTOS, A.R.; RIBEIRO, D.A.; CESAR, A.; GUIMARÃES, L.L. 2016. Occurrence of pharmaceuticals and cocaine in a Brazilian coastal zone. Science of the Total Environment, 548-549:148$154 \mathrm{p}$.

PERRON, M.M.; HO, K.T.; CANTWELL, M.G.; BURGESS, R.M.; PELLETIER, M.C. 2012. Effects of triclosan on marine benthic and epibenthic organisms. Environ Toxicol Chem., 31(8):1861-1866p.

PETRIE, B.; BARDEN, R.; KASPRZYK-HORDERN, B. 2015. A review on emerging contaminants in wastewaters and the environment: Current knowledge, understudied areas and recommendations for future monitoring. Water Research, 72:3-27p.

PHILLIPS, M.L \& MUIRDEN, K.D. 1972. An effect of ibuprofen and prednisolone on lysosomes. Letters to the Editor J. Pharm. Pharmac., 24:653-654p.

PIMENTEL, M.F.; DAMASCENO, E.P.; JIMENEZ, P.C.; ARAÚJO, P.F.R.; BEZERRA, M.F.; MORAIS, P.C.V.; CAVALCANTE, R.M.; LOUREIRO, S.; LOTUFO, L.V.C. 2016. 
Endocrine disruption in Sphoeroides testudineus tissues and sediments highlights contamination in a northeastern Brazilian estuary. Environ Monit Assess., 188:298p.

PINTADO-HERRERA, M.G.; GONZÁLEZ-MAZO, E.; LARA-MARTíN, P.A. 2013. Environmentally friendly analysis of emerging contaminants by pressurized hot water extraction-stir bar sorptive extraction-derivatization and gas chromatography-mass spectrometry. Anal Bioanal Chem., 405:401-411p.

PINTADO-HERRERA, M.G.; GONZÁLEZ-MAZO, E.; LARA-MARTÍN, P.A. 2014. Determining the distribution of triclosan and methyl triclosan in estuarine settings. Chemosphere, 95:478-485p.

POJANA, G.; GOMIERO, A.; JONKERS, N.; MARCOMINI, A. 2007. Natural and synthetic endocrine disrupting compounds (EDCs) in water, sediment and biota of a coastal lagoon. Environment International, 33:929-36p.

PUSCEDDU, F.H. 2009. Avaliação ecotoxicológica do fármaco Triclosan para invertebrados de água doce com ênfase em ensaios com sedimento marcado ("spiked sediment"). Dissertação de Mestrado. Instituto de Pesquisas Energéticas e Nucleares da Universidade de São Paulo. 116p.

PUSCEDDU, F.H.; ALEGRE, G.F.; PEREIRA, C.D.S. \& CESAR, A. 2007. Avaliação da Toxicidade do Sedimento do Complexo Estuarino de Santos Empregando Ouriços-domar Lytechinus variegatus (Echinoidea: Echinodermata). J. Braz. Soc. Ecotoxicol., 2(3):237-242p.

QUINN, B.; SCHMIDT, W.; O'ROURKE, K.; HERNAN, R. 2011. Effects of the pharmaceuticals gemfibrozil and diclofenac on biomarker expression in the zebra mussel (Dreissena polymorpha) and their comparison with standardised toxicity tests. Chemosphere, 84:657-663p.

QUINN, B.; GAGNÉ, F.; BLAISE, C. 2004. Oxidative metabolism activity in Hydra attenuata exposed to carbamazepine. Fresenius Environmental Bulletin, 13(8):783-788p. 
RACHID, B.R.F. 2002. Avaliação ecotoxicológica dos efluentes domésticos lançados pelos sistemas de disposição oceânica da Baixada Santista. Tese de Doutorado, Universidade de São Paulo, Instituto Oceanográfico. São Paulo. 286p.

RAND, G.M.; WELLS, P.G.; MACCARTY, L.S. 1995. Introduction to Aquatic Toxicology. In: RAND, G.M. Fundamentals of aquatic toxicology. Effects, environmental fate and risk assessment. Washington USA: Taylor \& Francis.

RIGONATO, J.; MANTOVANI, M.S. \& JORDÃO, B.Q. 2005. Comet assay comparison of different Corbicula fluminea (Mollusca) tissues for the detection of genotoxicity. Genetics and Molecular Biology, 28(3):464-468p.

RINGWOOD, A.H.; HOGUET, J.; KEPPLER, C.; GIELAZYN, M. 2004. Linkages between cellular biomarker responses and reproductive success in oysters - Crassostrea virginica. Marine Environmental Research, 58:151-155p.

SANCHEZ-PRADO, L.; LLOMPART, M.; LORES, M.; GARCÍA-JARES, C; BAYONA, J.M.; CELA, R. 2006. Monitoring the photochemical degradation of triclosan in wastewater by UV light and sunlight using solid-phase microextraction. Chemosphere, 65:1338$1347 p$.

SANTOS, D.R.A. 2012. Avaliação ecotoxicológica do fármaco cloridrato de fluoxetina e do surfactante dodecil sulfato de sódio quando submetidos a tratamento por radiação ionizante. Dissertação de Mestrado. Instituto de Pesquisas Energéticas e Nucleares da Universidade de São Paulo. 110p.

SCHOLZ, S. \& GUTZEIT, H.O. 2000. 17-a-ethinylestradiol affects reproductive, sexual differention and aromatase gene expression of the medaka (Oryzias latipes). Aquat Toxicol., 50:363-73p.

SHUGART, L.R. 1995. Environmental genotoxicology. In: RAND, G.M. (Ed.), Fundamentals of Aquatic Toxicology: Effects, Environmental Fate, and Risk Assessment. Taylor \& Francis, Bristol, PA, 405-420p. 
SIMM, M. 2009. Avaliação da qualidade da água em amostras provenientes da Baía da Babitonga - SC, através de ensaios de embriotoxicidade e de exposição prolongada ao ar, utilizando mexilhão da espécie Perna perna (linnaeus, 1758) na fase larval e adulta. Dissertação de Mestrado. Universidade de Joinville - UNIVILLE. 107p.

SINGER, H.; MÜLLER, S.; TIXIER, C.; PILLONEL, L. 2002. Triclosan: Occurrence and Fate of a Widely Used Biocide in the Aquatic Environment: Field Measurements in Wastewater Treatment Plants, Surface Waters, and Lake Sediments. Environ. Sci. Technol., 36:4998-5004p.

SMITH, R.J.; SABIN, C.; GILCHREST, H.; WILLIAMS, S. 1976. Effect of anti-inflammatory drugs on lysosomes and lysosomal enzymes from rat liver. Biochemical Pharmacology, 15:2171-2177p.

SODRÉ, F.F.; MONTAGNER, C.C.; LOCATELLI, M.A.F.; JARDIM, W.F. 2007. Ocorrência de Interferentes Endócrinos e Produtos Farmacêuticos em Águas Superficiais da Região de Campinas (SP, Brasil). Journal of the Brazilian Society of Ecotoxicology, 2(2):187-196p.

SOUSA, E.C.P.M.; ABESSA, D.M.S.; RACHID, B.R.F.; GASPARRO, M.R. \& ZARONI, L.P. 2007. Ecotoxicological assessment of sediments from the port of Santos and the disposal sites of dredged material. Braz. J. Oceanogr., 55:75-81p.

SOUSA, E.C.P.M.; ZARONI, L.P.; GASPARRO, M.R. \& PEREIRA, C.D.S. 2014. Review of ecotoxicological studies of the marine and estuarine environments of the Baixada Santista (São Paulo, Brazil). Brazilian Journal of Oceanography, 62(2):133-147p.

SOUSA, D.N.R; GROSSELI, G.M; MOZETO, A.A.; CARNEIRO, R.L.; FADIN, P.S. 2015. Ultrasound-assisted extraction method for the simultaneous determination of emerging contaminants in freshwater sediments. Journal of Separation Science, 38(19):34543460p.

SOUZA, M.S.; HALLGREN, P.; BALSEIRO, E.; HANSSON, L-A. 2013. Low concentrations, potential ecological consequences: Synthetic estrogens alter life-history 
and demographic structures of aquatic invertebrates. Environmental Pollution, 178:237$243 p$.

SPEIT, G. \& HARTMANN, A. 1995. The contribution of excision repair to the DNA effects seen in the alkaline single cell gel test (comet assay). Mutagenesis, 10:555-559p.

STRESSER, D.M.; BLANCHARD, A.P.; TURNER, S.D.; ERVE, J.C.; DANDENAU, A.A.; MILLER, V.P.; CRESPI, C.L. 2000. Substrate-dependent modulation of CYP3A4 catalytic activity: analysis of 27 test compounds with four fluorometric substrates. Drug Metab. Dispos, . 28:1440-1448p.

STUMPF, M.; TERNES, T.A.; WILKEN, R.; RODRIGUES, S.V.; BAUMANN, W. 1999. Polar drug residues in sewage and natural waters in the state of Rio de Janeiro, Brazil. The Science of the Total Environment, 255:135-141p.

TAKAHASHI, T.; KOZAKI, K.; YATABE, Y.; ACHIWA, H.; HIDA, T. 2002. Increased expression of COX-2 in the development of human lung cancers. J Environ Pathol Toxicol Oncol., 21(2):177-81p.

TERNES, T.A.; ANDERSEN, H.; GILBERG, D.; BONERZ, M. 2002. Determination of Estrogens in Sludge and Sediments by Liquid Extraction and GC/MS/MS. Anal. Chem., 74:3498-3504p.

THOMAS, K.V. \& HILTON, M.J. 2004. The occurrence of selected human pharmaceutical compounds in UK estuaries. Mar. Pollut. Bull., 49:436-444p.

THOMPSON, C.B. 1995. Apoptosis in the pathogenesis and treatment of disease. Science, 267:1456-1462p.

TOMA, W.; GUIMARÃES, L.L.; BRITO, A.R.M.S.; SANTOS, A.R.; CORTEZ, F.S.; PUSCEDDU, F.H.; CESAR, A.; JÚNIOR, L.S.; PACHECO, M.T.T.; PEREIRA, C.D.S. 2014. Safflower oil: an integrated assessment of phytochemistry, antiulcerogenic activity, and rodent and environmental toxicity. Rev Bras Farmacogn., 24:538-544p. 
TOMMASI, L.R. 1979. Considerações ecológicas sobre o Sistema Estuarino de Santos, São Paulo. Tese de Livre Docência. Instituto Oceanográfico da Universidade de São Paulo, São Paulo. 2vols.

UNEP - United Nations Environment Programme. 1999. Mediterranean Action Plan Manual on the biomarkers recommended for the MED POL biomonitoring programme. UNEP, Athens.

USEPA - United States Environmental Protection Agency. 2015. Contaminants of Emerging Concern including Pharmaceuticals and Personal Care Products. Disponível em: $\quad$ http://www.epa.gov/wqc/contaminants-emerging-concern-includingpharmaceuticals-and-personal-care-products.

USEPA - United States Environmental Protection Agency. 2008a. Reregistration Eligibility Decision for Triclosan. List B. Case No. 2340. 98p.

USEPA - United States Environmental Protection Agency. 2008b. Revised Environmental Fate Science Chapter for the Triclosan Reregistration Eligibility Decision (RED) Document. DP Barcode: 343543. Reregistration Case o․: 2340.

USEPA - United States Environmental Protection Agency. 2007. Method 1694: pharmaceuticals and personal care products in water, soil, sediment, and biosolids by HPLC/MS/MS. Office of Water, Office of Science and Technology, Engineering and Analysis Division. [EPA-821-R-08-002].

USEPA - United States Environmental Protection Agency. 2002. Short-term Methods for Estimating the Chronic Toxicity of Effluents and Receiving Waters to Freshwater Organisms. Fourth Edition. [EPA-821-R-02-013].

USEPA - United States Environmental Protection Agency. 2001. Technical Manual. Methods for collection, storage and manipulation of sediments for chemical and toxicological analyses. Chapter 5: Sediment Manipulations. 
USEPA - United States Environmental Protection Agency. 1995. Short-term methods for estimating the chronic toxicity of effluents and receiving waters to west coast marine and estuarine organisms. First edition. [EPA/600/R-95-136].

USEPA - United States Environmental Protection Agency. 1993. Technical Basis for Deriving Sediment Quality Criteria for Nonionic Organic Contaminants for the Protection of Benthic Organisms by Using Equilibrium Partitioning. [EPA-822-R-93-011].

VENKATESAN, A.K.; PYCKE, B.F.G.; BARBER, L.B.; LEE, K.E.; HALDEN, R.U. 2012. Occurrence of triclosan, triclocarban, and its lesser chlorinated congeners in Minnesota freshwater sediments collected near wastewater treatment plants. Journal of Hazardous Materials, 229-230:29-35p.

VIARENGO, A.; LOWE, D.; BOLOGNESI, C.; FABBRI, E.; KOEHLER, A. 2007. The use of biomarkers in biomonitoring: A 2-tier approach assessing the level of pollutant-induced stress syndrome in sentinel organisms. Review. Comparative Biochemistry and Physiology, Part C, 146:281-300p.

VIGNARDIA, C.P.; HASUE, F.M.; SARTÓRIO, P.V.; CARDOSO, C.M.; MACHADO, A.S.D.; PASSOS, M.J.A.C.R.; SANTOS, T.C.A.; NUCCI, J.M.; HEWER, T.L.R.; WATANABE, L-S.; GOMES, V.; PHAN, N.V. 2015. Genotoxicity, potential cytotoxicity and cell uptake of titanium dioxide nanoparticles in the marine fish Trachinotus carolinus (Linnaeus, 1766). Aquatic Toxicology, 158:218-229p.

VILLALAÍN, J.; MATEO, C.R.; ARANDA, F.J.; SHAPIRO, S.; MICOL, V. 2001. Membranotropic effects of the antibacterial agent Triclosan. Arch Biochem Biophys., 390(1):128-36p.

WALKER, C.H.; HOPKIN, S.P.; SIBLY, R.M.; PEAKALL, D.B. 1996. Principles of Ecotoxicology. Londres: Taylor \& Francis. 312p.

WALTERS, E.; MCCLELLAN, K.; HALDEN, R.U. 2010. Occurrence and loss over three years of 72 pharmaceuticals and personal care products from biosolids-soil mixtures in outdoor mesocosms. Water Research, 44:6011-6020p. 
WEIGEL, S.; BERGER, U.; JENSEN, E.; KALLENBORN, R.; THORESEN, H.; HUHNERFUSS, H. 2004. Determination of selected pharmaceuticals and caffeine in sewage and seawater from Tromso/Norway with emphasis on ibuprofen and its metabolites. Chemosphere, 56:583-592p.

WENTWORTH, C.H. 1922. A scale of grade and class terms for clastic sediments. The Journal of Geology, 30(5):377-392p.

WEST, Inc \& GULLEY, D. Western Ecosystems Technology. TOXTAT 3.5 Computer Program, 1996.

WILLS, E.D. 1987. Evaluation of lipid peroxidation in lipids and biological membranes. In: SNELL, K. \& MULLOCK, B. (eds.), Biochemical Toxicology: A Practical Approach. IRL Press, Washington, USA, 127-150pp.

WILSON, B.; CHEN, R.F.; CANTWELL, M.; GONTZ, A.; ZHU, J.; OLSEN, C.R. 2009. The partitioning of Triclosan between aqueous and particulate bound phases in the Hudson River Estuary. Marine Pollution Bulletin, 59:207-212p.

WINSTON, G.W. 1991. Oxidants and antioxidants in aquatic animals. Comp. Biochem. Physiol. V.100C. N.1/2: 173-176.

XIE, Z.; EBINGHAUS, R.; FLÖSER, G.; CABA, A.; RUCK, W. 2008. Occurrence and distribution of triclosan in the German Bight (North Sea). Environmental Pollution, 156:1190-1195p.

ZARONI, L.P.; ABESSA, D.M.S; LOTUFO, G.R.; SOUSA, E.C.P.M.; PINTO, Y.A. 2005. Toxicity testing with embryos of marine mussels: protocol standardization for Perna perna (Linnaeus, 1758). Bull. Environ. Contam. Toxicol., 74:793-800p.

ZHANG, X.J.; YANG, L.; ZHAO, Q.; CAEN, J.P.; HE, H.Y.; JIN, Q.H.; GUO, L.H.; ALEMANY, M.; ZHANG, L.Y.; SHI, Y.F. 2002. Induction of acetylcholinesterase expression during apoptosis in various cell types. Cell Death and Differentiation, 9:790$800 p$. 
ZHANG, X.; LI, Q.; LI, G.; WANG, Z.; YAN, C. 2009. Levels of estrogenic compounds in Xiamen Bay sediment, China. Marine Pollution Bulletin, 58:1210-1216p.

ZHANG, X.; GAO, Y.; LI, G.; GUO, Q.; YAN, C. 2011. Estrogenic Compounds and Estrogenicity in Surface Water, Sediments, and Organisms from Yundang Lagoon in Xiamen, China. Arch Environ Contam Toxicol., 61:93-100p.

ZHAO, J-L.; YING, G-G; LIU, Y-S; CHEN, F; YANG, J-F; WANG, L. 2010. Occurrence and risks of triclosan and triclocarban in the Pearl River system, South China: From source to the receiving environment. J Hazard Mater., 179:215-222p.

ZHAO, J-L.; ZHANG, Q-Q.; CHEN, F.; WANG, L.; YING, G-G; LIU, Y-S.; YANG, B.; ZHOU, L-J.; LIU, S.; SU, H-C.; ZHANG, R-Q. 2013. Evaluation of triclosan and triclocarban at river basin scale using monitoring and modeling tools: Implications for controlling of urban domestic sewage discharge. Water Research, 47:395-405p.

ZHOU, X.; LIAN, Z.; WANG, J.; TAN, L.; ZHAO, Z. 2011. Distribution of estrogens along Licun River in Qingdao, China. Procedia Environmental Sciences, 10:1876-1880p.

ZUO, Y.; ZHANG, K.; DENG, Y. 2006. Occurence and photochemical degradation of $17 \alpha$ ethinylestradiol in Acushnet River Estuary. Chemosphere, 63:1583-90p.

ZUO, Y.; ZHANG, K.; ZHOU, S. 2013. Determination of estrogenic steroids and microbial and photochemical degradation of 17a-ethinylestradiol (EE2) in lake surface water, a case study. Environ. Sci.: Processes Impacts, 15:1529-1535p. 